\title{
Citrus species: Modern functional food and nutraceutical-based product ingredient
}

\author{
Mariarosaria Leporini ${ }^{1}$, Rosa Tundis ${ }^{1}$, Vincenzo Sicari ${ }^{2}$, Monica Rosa Loizzo $^{1 \%}$ \\ ${ }^{1}$ Department of Pharmacy, Health and Nutritional Sciences, University of Calabria, 87036 Rende (CS), Italy; ${ }^{2}$ Department \\ of Agraria, "Mediterranea" University of Reggio Calabria, Cittadella Universitaria, Località Feo di Vito 89124 Reggio \\ Calabria (RC), Italy
}

*Corresponding Author: Monica Rosa Loizzo, Department of Pharmacy, Health and Nutrition Science, University of Calabria, via P. Bucci, Edificio Polifunzionale, 87036 Rende (CS), Italy. Email: monica_rosa.loizzo@unical.it

Received: 25 January 2021; Accepted: 22 April 2021; Published: 27 May 2021

(C) 2021 Codon Publications

OPEN ACCESS (C) (1)(2)

REVIEW

\begin{abstract}
Citrus is the most cultivated fruit crop in the world and occupies a place of considerable importance in the country's economy. Almost 33\% of the citrus fruits are processed for juice production; however, a great amount of wastes, including peels, segment membranes, and seeds are also produced. Indeed, citrus fruits consist of $45 \%$ juice, $26 \%$ pulp, $27 \%$ peels, and $2 \%$ seeds. Pruning, a cultural practice involving the removal of tree branches and limbs, was applied to improve fruit's quality. A large amount of leaves are produced through pruning. These agrifood matrices contain a wide range of bioactive phytochemicals compared to fruits. The present review covers the past 5 years of research carried out in chemistry, health properties, and applications in food and nutraceutical industries of all portions of citrus fruit and its major bioactive compounds. Additionally, patents are also included.
\end{abstract}

Keywords: bioactive compounds, by-products, citrus, health properties, juice, peels, pulp, seeds

\section{Introduction}

Citrus is the most cultivated fruit tree in the world and occupies a place of considerable importance in country's economy. The citrus fruits are processed for juice production $(45 \%)$, and a great amount of waste, including peels (27\%), pulp (26\%) and seeds (2\%), is produced (Mahato et al., 2018).

Food waste is defined as the by-product obtained from various industrial, agricultural and other activities of food sector. Especially, food-processing industries produce large quantities of by-products, which are difficult to dispose of as they have a high demand for biological oxygen. Indeed, waste disposal has high costs and, also a potential negative impact on the environment (Kumar et al., 2017).

These agri-food matrices contain a wide range of bioactive phytochemicals with different structures and functionality that could be used as ingredients for food, food supplements or active bioactive compounds in pharmaceutical products (Rombaut et al., 2014).

In food industry, citrus by-products and their value-added compounds, including polyphenols, vitamins, microelements and fiber are utilized as natural additives with the following properties: antimicrobials, antioxidants, colorants and flavoring agents (Mahato et al., 2019). These wastes have gained increasing interest for further exploitation on the production of food additives, supplements with high nutritional value and pharmaceutical products.

The recent data were collected from several scientific databases (PubMed, Science Direct, SciFinder, Scopus, Elsevier, SpringerLink, ReserchGate and Google Scholar) from 2015 to 2020 using the following keywords: citrus, citrus by-products, juice, seed, peels, leaves, and 
essential oils. This work is structured by dividing the text in Citrus portion and discussions on the phytochemical profile and biological activities of each. Additionally, patents are also included. The information collected would be useful for research on citrus species and for food and nutraceutical industries interested in using ingredients with health potential.

\section{Juice}

\section{Antioxidant activity}

Reactive oxygen species (ROS) and reactive nitrogen species (RNS) are involved in the pathogenesis of many human diseases, and antioxidants play a crucial role in restoring the physiological oxidative balance and modulating biological pathways and membrane functions (Smeriglio et al., 2018). The citrus genus is recognized for its protective effects against free radical-induced damage. Barberis et al. (2020) analyzed the antioxidant potential of fresh squeezed pompia, lemon (cv. Lisbon) and orange juices (cv. Hamlin, Sanguinello, and Moro). Among these, Pompia juice had a marked effect against ROS, and a moderate capacity to reduce ROS damages on cell membrane. On the contrary, orange juices resulted much less effective. The in vitro antioxidant potential (Table 1) of fresh squeezed citrus $\times$ clementina juices, collected from different areas of Calabria, was recently evaluated (Leporini et al., 2020a). Results revealed that juice obtained from fruits collected in Corigliano Calabro exhibited the highest radical activity, with the concentration giving 50\% inhibition $\left(\mathrm{IC}_{50}\right)$ values of 81.13 and $27.82 \mathrm{mg} / \mathrm{mL}$ for 2,2-diphenyl-1-picrylhydrazyl (DPPH) and 2,2'-azinobis (3-ethylbenzothiazoline-6-sulfonic acid) diammonium salt (ABTS) tests, respectively. The same juice exhibited the highest protection of lipid peroxidation. These results are similar to the previous study conducted by Loizzo et al. (2018) that reported the antioxidant activity of fresh squeezed citrus $\times$ clementina juices from fruits collected in flood plains, hills, and coastal plains of Sibari (Calabria, Italy). The following trend of radical potency was found: flood plain > coastal plain $>$ hill.

Haraoui et al. (2020) compared the antioxidant activity of fresh squeezed juices derived from different citrus fruit varieties. All investigated samples possessed radical scavenging activity with $\mathrm{IC}_{50}$ values comparable to positive control ascorbic acid and butylated hydroxytoluene (BHT). Among them, Citrus maxima and Citrus aurantium juices showed the highest DPPH radical scavenging activity $\left(\mathrm{IC}_{50}=0.42\right.$ and $0.44 \mathrm{mg} / \mathrm{mL}$, respectively). The same trend was observed in $\beta$-carotene bleaching test with percentage exceeding to $80.55 \%$, followed by Citrus sinensis cv. Sanguinelli and Citrus limon.
The antioxidant ability of fresh squeezed Citrus limon L. Burm. cv. Femminello comune juice was analyzed by Loizzo et al. (2019), founding the $\mathrm{IC}_{50}$ values of 40.3 and $46.5 \mathrm{~g} / \mathrm{mL}$ in DPPH and ABTS test, respectively, and $49.7 \mathrm{mg} \mathrm{Fe}$ (II)/g in the ferric-reducing ability power (FRAP) test. More recently, the antioxidant ability of two Citrus sinensis cultivars (Sanguinelli and Salustiana) was demonstrated by applying ABTS, DPPH, and ORAC assays (Ordóñez-Díaz et al., 2020). Citrus sinensis cv. Sanguinelli extracts were $40 \%$ more active than Citrus sinensis Salustiana samples.

Recently, Ali et al. (2020) reported that animals treated with $0.75 \%$ hydrogen peroxide in drinking water with daily drenching with $1 \mathrm{~mL}$ lemon juice, exhibited enhancement in hemoglobin concentration, red blood cells count, white blood cells count, and total proteins, and reduction in the level of aspartate aminotransferase and alanine aminotransferase. These findings clearly confirmed the protective and antioxidant features of lemon juice on hematological and biochemical parameters of the oxidatively stressed female mice.

\section{Metabolic syndrome}

Metabolic syndrome (MS) is a clustering characterized by abdominal obesity, high blood pressure, high blood sugar, high serum triglycerides (TG), low serum, and high-density lipoprotein (HDL) that directly increase the risk of cardiovascular disease, type 2 diabetes mellitus (T2DM), and all-cause mortality (Kaur et al., 2014).

Recently, the beneficial effects of Citrus bergamia juice were evaluated using an experimental animal model of MS and cardiovascular risk (De Leo et al., 2020). Results demonstrated that daily oral treatment reduced TG levels, cardiovascular risk, and showed protective effects on hepatic steatosis, probably due to the reduction of oxidative stress and inflammation. Previously, Impellizzeri et al. (2015) tested the in vivo anti-inflammatory activity of bergamot juice extract. Mice treated with this extract were more resistant to induction of colitis and reduction in the expression of important inflammatory mediators, tumor necrosis factor-alpha (TNF- $\alpha$ ) and interleukin-1 $\beta$ (IL-1 $\beta)$, was observed.

The effects of a bergamot phytocomplex (Patent No. EP3116520A1) was investigated by Di Folco et al. (2018). Each tablet provided 200-mg bergamot juice dry extract, 120-mg phytosterols, 80-mg artichoke leaf extract, and 20 -mg vitamin citrus. After 6 months of administration, patients in the intervention group showed a significant reduction in fasting blood glucose compared to the simple dietary intervention alone. 
Table 1. Biological effects of Citrus juices.

\begin{tabular}{|c|c|c|c|c|}
\hline Juice & $\begin{array}{l}\text { Biological } \\
\text { activity }\end{array}$ & Mechanism & $\begin{array}{l}\text { TPC, TFC, TCC, and/or main } \\
\text { abundant identified compounds }\end{array}$ & References \\
\hline \multicolumn{5}{|l|}{ In vitro } \\
\hline \multirow[t]{2}{*}{$\begin{array}{l}\text { Citrus } \\
\text { aurantifolia }\end{array}$} & Antioxidant & $\begin{array}{l}\text { Radical scavenging } \\
\text { Ferric-reducing power }\end{array}$ & $\begin{array}{l}\mathrm{TPC}=52 \mathrm{mg} \mathrm{GAE} / \mathrm{L} ; \\
\mathrm{TFC}=29.5 \mathrm{mg} \mathrm{QE} / \mathrm{L}\end{array}$ & Oboh et al., 2015b \\
\hline & Antibacterial & $\begin{array}{l}\text { S. aureus, S. epidermis, M. luteus, } \\
\text { E. faecalis, B. subtillis, P. aeruginosa, } \\
\text { K. pneumonia S. thypii, and } \\
\text { C. diphtheriae inhibition }\end{array}$ & $\begin{array}{l}\text { NR } \\
\text { NR } \\
\text { NR }\end{array}$ & $\begin{array}{l}\text { Abdallah, } 2020 \\
\text { Fadillah et al., } 2020 \\
\text { Azhara et al., } 2020\end{array}$ \\
\hline \multirow[t]{2}{*}{ Citrus aurantium } & Antioxidant & Radical scavenging & $\begin{array}{l}\text { TPC = } 295.37 \mathrm{mg} \mathrm{GAE} / \mathrm{g} ; \\
\text { FC = 26.08 mg QE } / \mathrm{g} \\
\text { TPC = } 0.58 \mathrm{mg} \mathrm{GAE} / \mathrm{mL} ; \\
\text { TFC = 0.43 mg RE } / \mathrm{mL} ; \\
\text { Neohesperidin = } 144.85 \mathrm{mg} / \mathrm{mL} ; \\
\text { Naringin = } 79.19 \mathrm{mg} / \mathrm{mL} ; \\
\text { Hesperidin = } 4.68 \mathrm{mg} / \mathrm{mL}\end{array}$ & $\begin{array}{l}\text { Haraoui et al., } 2020 \\
\text { Chen et al., } 2020\end{array}$ \\
\hline & Antibacterial & S. aureus inhibition & & Haraoui et al. 2020 \\
\hline Citrus grandis & Antioxidant & Radical scavenging & $\begin{array}{l}\text { TPC = 0.49-1.27 mg GAE } / \mathrm{mL} ; \\
\text { TFC = 0.35-1.17 mg RE } / \mathrm{mL} ; \\
\text { Naringin = 40.82-419.28 mg/mL; } \\
\text { Neohesperidin = 37.52-42.54 mg/mL; } \\
\text { Hesperidin = 3.14-12.17 mg/mL; } \\
\text { Diosmin = 14.79-21.38 mg/mL; } \\
\text { Tangeretin = 3.09-3.64mg/mL. }\end{array}$ & Chen et al., 2020 \\
\hline Citrus hystrix & Antibacterial & S. aureus inhibition & NR & $\begin{array}{l}\text { Kusumawardhani } \\
\text { et al., } 2020\end{array}$ \\
\hline \multirow[t]{4}{*}{ Citrus limon } & Antioxidant & Radical scavenging & $\begin{array}{l}\text { TPC = } 151.7 \mathrm{mg} \mathrm{GAE} / \mathrm{L} ; \\
\text { TFC = } 30.8 \mathrm{mg} \mathrm{QE} / \mathrm{L} ; \\
\text { Eriocitrin = } 16.7 \mathrm{mg} / 100 \mathrm{~mL} ; \\
\text { Hesperidin = } 14.1 \mathrm{mg} / 100 \mathrm{~mL} .\end{array}$ & Loizzo et al., 2019 \\
\hline & $\begin{array}{l}\text { Metabolic } \\
\text { syndrome }\end{array}$ & $\begin{array}{l}\text { Inhibition of } \alpha \text {-amylase and } \\
\beta \text {-glucosidase enzymes }\end{array}$ & & Loizzo et al., 2019 \\
\hline & Antibacterial & $\begin{array}{l}\text { S. aureus, S. epidermis, M. luteus, } \\
\text { E. faecalis and B. subtillis inhibition. }\end{array}$ & $\begin{array}{l}\text { TPC }=231.16 \mathrm{mg} \mathrm{GAE} / \mathrm{g} \\
\mathrm{TFC}=25.04 \mathrm{mg} \mathrm{QE} / \mathrm{g}\end{array}$ & Haraoui et al. 2020 \\
\hline & Neuroprotective & AChE and BChE inhibition & $\begin{array}{l}\text { Diosmetin 6,8-di-C-glucoside = } \\
5.35 \mathrm{mg} / 100 \mathrm{~mL} \text {; } \\
\text { Hesperetin 7-O-rutinoside = } \\
3.11 \mathrm{mg} / 100 \mathrm{~mL} \text {. }\end{array}$ & $\begin{array}{l}\text { Gironés-Vilaplana } \\
\text { et al., } 2015\end{array}$ \\
\hline \multirow[t]{2}{*}{ Citrus maxima } & Antioxidant & Radical scavenging & $\begin{array}{l}\mathrm{TPC}=350.05 \mathrm{mg} \mathrm{GAE} / \mathrm{g} \\
\mathrm{TFC}=55.38 \mathrm{mg} \mathrm{QE} / \mathrm{g}\end{array}$ & Haraoui et al., 2020 \\
\hline & Antibacterial & $\begin{array}{l}\text { S. aureus, S. epidermis, M. luteus, } \\
\text { E. faecalis and B. subtillis inhibition. }\end{array}$ & & Haraoui et al. 2020 \\
\hline Citrus medica & Antioxidant & Radical scavenging & $\begin{array}{l}\text { TPC = 0.30-1.37 mg GAE } / \mathrm{mL} ; \\
\text { TFC = 0.19-0.68 mg RE/mL; } \\
\text { Hesperidin = } 42.13 \mathrm{mg} / \mathrm{mL} ; \\
\text { Eriocitrin = } 28.46 \mathrm{mg} / \mathrm{mL} ; \\
\text { Narirutin = } 28.46 \mathrm{mg} / \mathrm{mL} ; \\
\text { Didymin = } 12.50 \mathrm{mg} / \mathrm{mL} ; \\
\text { Tangeretin = } 3.76 \mathrm{mgmL}\end{array}$ & Chen et al., 2020 \\
\hline Citrus paradisi & Antioxidant & Radical scavenging & $\begin{array}{l}\text { TPC = } 153.08 \mathrm{mg} / \mathrm{mL} ; \\
\text { TFC = } 390.21 \mathrm{mg} / \mathrm{mL} ; \\
\text { Naringin = } 287.15 \mathrm{mg} / \mathrm{mL} ; \\
\text { Narirutin = } 37.07 \mathrm{mg} / \mathrm{mL} ; \\
\text { Naringenin = } 31.25 \mathrm{mg} / \mathrm{mL} ; \\
\text { Poncirin = } 17.32 \mathrm{mg} / \mathrm{mL} ; \\
\text { Neohesperidin = } 13.48 \mathrm{mg} / \mathrm{mL} .\end{array}$ & Sicari et al., 2018 \\
\hline
\end{tabular}


Table 1. Continued

\begin{tabular}{|c|c|c|c|c|}
\hline Juice & $\begin{array}{l}\text { Biological } \\
\text { activity }\end{array}$ & Mechanism & $\begin{array}{l}\text { TPC, TFC, TCC, and/or main } \\
\text { abundant identified compounds }\end{array}$ & References \\
\hline Citrus reticulata & Antioxidant & Radical scavenging & $\begin{array}{l}\text { TPC = 0.30-1.37 mg GAE } / \mathrm{mL} ; \\
\text { TFC = 0.19-0.68 mg RE } / \mathrm{mL} ; \\
\text { Hesperidin = 50.53-141.85 mg/mL; } \\
\text { Naringin = 26.57-78.39 mg/mL; } \\
\text { Neohesperidin = 69.19 mg/mL; } \\
\text { Didymin = 1.73-10.33 mgmL; } \\
\text { Eriocitrin = 27.17-78.39 mg/mL; } \\
\text { Tangeretin = 3.43-4.32 mg/mL. }\end{array}$ & Chen et al., 2020 \\
\hline Citrus sinensis & Antioxidant & Radical scavenging & $\begin{array}{l}\text { TPC = 0.47-0.67 mg GAE } / \mathrm{mL} ; \\
\text { TFC = 0.23-0.92 mg RE } / \mathrm{mL} ; \\
\text { Hesperidin = 94.98-173.11 mg/mL; } \\
\text { Eriocitrin = 28.38-46.95 mg/mL; } \\
\text { Narirutin = 28.38-46.95 mg/mL; } \\
\text { Didymin = 1.73-10.33 mg/mL; } \\
\text { Tangeretin = 3.52-3.67 } \mu \mathrm{g} / \mathrm{mL}\end{array}$ & Chen et al., 2020 \\
\hline \multirow[t]{3}{*}{$\begin{array}{l}\text { Citrus } \times \\
\text { clementina }\end{array}$} & Antioxidant & $\begin{array}{l}\text { Radical scavenging } \\
\text { Ferric-reducing power } \\
\text { Inhibition of lipid peroxidation }\end{array}$ & $\begin{array}{l}\text { TPC = 17.58-54.65 mg CAE } / 100 \mathrm{~mL} ; \\
\text { TFC = 18.16-51.48 mg QE/100 mL; } \\
\text { TCC = 18.23-53.54 mg } \beta \text {-carotene } \\
\text { E/100 mL; } \\
\text { Neohesperidin = 80.26-110 mg/ } \\
100 \mathrm{~mL} ; \\
\text { Hesperidin = 40-81.08 mg/100 mL; } \\
\text { Naritutin = 6.25-8.50 mg/100 mL. } \\
\text { TPC = 29.74-44.20 mg GAE } / 100 \mathrm{~mL} ; \\
\text { TCC = 42.89-75.45 mg } \beta \text {-carotene } \\
\text { E/100 mL; } \\
\text { Neohesperidin = } 72.96-116.50 \mathrm{mg} / 100 \\
\mathrm{~mL} ; \\
\text { Hesperidin = 55.24-69.52 mg/100 mL; } \\
\text { Didymin = 3.65-5.65 mg/100 mL }\end{array}$ & $\begin{array}{l}\text { Leporini et al., } \\
\text { 2020a } \\
\text { Loizzo et al., } 2018\end{array}$ \\
\hline & $\begin{array}{l}\text { Metabolic } \\
\text { syndrome }\end{array}$ & $\begin{array}{l}\text { Inhibition of } \alpha \text {-amylase, } \\
\beta \text {-glucosidase and lipase enzymes }\end{array}$ & & $\begin{array}{l}\text { Leporini et al., } \\
\text { 2020a } \\
\text { Loizzo et al., } 2018\end{array}$ \\
\hline & Antibacterial & M. luteus and $B$. subtillis inhibition & $\begin{array}{l}\mathrm{TPC}=75.60 \mathrm{mg} \mathrm{GAE} / \mathrm{g} \\
\mathrm{TFC}=20.51 \mathrm{mg} \mathrm{QE} / \mathrm{g}\end{array}$ & Haraoui et al. 2020 \\
\hline \multicolumn{5}{|l|}{ In vivo } \\
\hline $\begin{array}{l}\text { Citrus } \\
\text { aurantifolia }\end{array}$ & $\begin{array}{l}\text { Metabolic } \\
\text { syndrome }\end{array}$ & $\begin{array}{l}\text { Reduction in plasma TC, TG, and } \\
\text { LDL-c levels and increase in plasma } \\
\text { HDL-cholesterol levels. }\end{array}$ & & Oboh et al., 2015b \\
\hline Citrus bergamia & $\begin{array}{l}\text { Metabolic } \\
\text { syndrome }\end{array}$ & $\begin{array}{l}\text { Reduction TG levels, cardiovascular } \\
\text { risk, oxidative stress and } \\
\text { inflammation, protective effects on } \\
\text { hepatic steatosis. }\end{array}$ & $\begin{array}{l}\text { Neohesperidin } 182.3 \mathrm{mg} / \mathrm{mL} \text {; } \\
\text { Neoeriocitrin = } 165.0 \mathrm{mg} / \mathrm{mL} \text {; } \\
\text { Naringin }=160.1 \mathrm{mg} / \mathrm{mL} \\
\text { Not reported }\end{array}$ & $\begin{array}{l}\text { De Leo et al., } 2020 \\
\text { Impellizzeri et al., } \\
2015\end{array}$ \\
\hline Citrus lemon & Antioxidant & Reduction in ROS levels & $\begin{array}{l}\text { Hesperidin = } 77.1 \mathrm{mg} / \mathrm{L} ; \\
\text { Isorhamnetin 3-O-rutinoside = } \\
44.9 \mathrm{mg} / \mathrm{L} ; \\
\text { Rhoifolin = } 31.4 \mathrm{mg} / \mathrm{L} ; \\
\text { Eriocitrin = } 29.9 \mathrm{mg} / \mathrm{L} ; \\
\text { Diosmin = } 25.7 \mathrm{mg} / \mathrm{L} \text {. }\end{array}$ & Barberis et al., 2020 \\
\hline \multirow[t]{2}{*}{ Citrus sinensis } & Antioxidant & ROS scavenger & $\begin{array}{l}\text { Hesperidin = } 422.8 \mathrm{mg} / \mathrm{L} \\
\text { Naringin = } 132.6 \mathrm{mg} / \mathrm{L} \\
\text { Narirutin = } 100.1 \mathrm{mg} / \mathrm{L}\end{array}$ & Barberis et al., 2020 \\
\hline & $\begin{array}{l}\text { Metabolic } \\
\text { syndrome }\end{array}$ & Reduction in body mass index & $\begin{array}{l}1 \text { tablet/die [day] containing } 400 \mathrm{mg} \\
\text { of Morosi }\left.\right|^{\circledR}\end{array}$ & Cardile et al., 2015 \\
\hline
\end{tabular}

NR: not reported; TPC: total phenolics content; TFC: total flavonoids content; TCC: total carotenoids content; ROS: Reactive Oxygen Species. 
The edible portion of hybrid Tacle ${ }^{\circ}$, a crossbreeding of Citrus $\times$ clementina and Tarocco tetraploids, was able to influence anthropometric values and lipid and glucose metabolism in a rat model having obesity and MS. For this reason, it could be included in dietary supplements for the management of metabolic disorders (Casacchia et al., 2019). A promising anti-obesity potential of fresh squeezed Citrus $\times$ clementina juices against lipase enzymes with $\mathrm{IC}_{50}$ values in the range of 179.32-197.69 $\mathrm{mg} / \mathrm{mL}$ was recently confirmed (Leporini et al., 2020a). Moro juice (Citrus sinensis) extract (Morosil ${ }^{\circ}, 400 \mathrm{mg} / \mathrm{die}$ [day]) was able to induce a significant reduction in body mass index (BMI) after 4 weeks of treatment (Cardile et al., 2015).

One important therapeutic approach for suppressing postprandial hyperglycemia is to reduce or bring down dietary carbohydrate digestion and absorption. The inhibition of carbohydrate-hydrolyzing enzymes, $\alpha$-glucosidase and $\alpha$-amylase, in the digestive tract also determined reduction in the rate of glucose absorption and consequently blunting the post-prandial plasma glucose rise (Tundis et al., 2010). The fresh squeezed Citrus lemon exhibited a promising hypoglycemic inhibitory potential with the $\mathrm{IC}_{50}$ values of 31.1 and $35.3 \mathrm{mg} / \mathrm{mL}$ against $\alpha$-amylase and $\alpha$-glucosidase enzymes, respectively (Loizzo et al., 2019) whereas values in the range of $67.19-103.43 \mu \mathrm{g} / \mathrm{mL}$ against $\alpha$-glucosidase were found for fresh squeezed Citrus $\times$ clementina juices from different areas of collection (Leporini et al., 2020a). The hypoglycemic ability of Poncirus trifoliata juice, related to the genus citrus, was investigated against $\alpha$-amylase and $\alpha$-glucosidase enzymes (Tundis et al., 2016), with the $\mathrm{IC}_{50}$ values of 138.14 and $81.27 \mu \mathrm{g} / \mathrm{mL}$, respectively.

\subsection{Antibacterial activity}

The development of antibiotic resistance by pathogenic microorganisms necessitated the quest for alternative drug therapy. Medicinal plants are traditionally recognized as conventional medicines, and numerous studies have confirmed their antibacterial activity (Gavarić et al., 2015). Haraoui et al. (2020) investigated the bacteriostatic action of citrus variety juices. Fresh squeezed citrus limon juice exhibited inhibition zone of $27.66 \mathrm{~mm}$ on Micrococcus luteus, followed by Citrus aurantium with an area of $24.66 \mathrm{~mm}$ against Staphylococcus aureus. Interesting results were observed also for Citrus maxima and citrus $\times$ clementina with inhibition zones of 23.00 and $17.66 \mathrm{~mm}$, respectively, against $M$. luteus. The lime fresh squeezed juice as antibacterial agent was confirmed against Salmonella thypii (Fadillah et al., 2020) and Corynebacterium diphtheriae (Azhara et al., 2020).

Growth of $S$. aureus was inhibited by fresh squeezed Citrus hystrix juice (Kusumawardhani et al., 2020).
Abdallah (2020) suggested Citrus aurantifolia as natural antibacterial agent against S. aureus, S. epidermis, Pseudomonas aeruginosa, and Klebsiella pneumonia. Low antibacterial activity was found for Citrus sinensis.

\section{Prebiotic effects}

The prebiotic effect of orange juice could be due to its positive effect on the intestinal microbiota and metabolic biomarkers of young women (aged 28.5 years) (Lima et al., 2019). Indeed, daily intake of orange juice $(300 \mathrm{~mL} /$ day for 2 months) did not change women's body composition, but improved blood biochemical parameters, such as low-density lipoprotein (LDL)-cholesterol, glucose, and insulin sensitivity. Additionally, orange juice positively modulated the composition and metabolic activity of microbiota, increasing the population of Bifidobacterium spp. and Lactobacillus spp and reduction of Enterobacteria. Reduction in ammonium $\left(\mathrm{NH}_{4}^{+}\right)$ and increase in the production of short-chain fatty acids were also demonstrated. More recently, this prebiotic effect in healthy female volunteers after intervention with 300-mL/day orange juice for 60 days was confirmed (Fidélix et al., 2020). Orange juice stimulated the growth of Lactobacillus spp. in the intestinal microbiota and improved glucose metabolism due to the probiotic effect of these bacteria.

Daily supplementation of juices of two oranges (cv. Cara Cara and cv. Bahia) with different flavanone content for 7 days in healthy volunteers resulted in increase in the abundance of Lachnospiraceae and Ruminococcaceae that represented the two most abundant phylum Firmicutes' families present in the gut environment (Brasili et al., 2019). Interestingly, after intake of Cara Cara juice positive correlations were found between Lachnospiraceae and butyrate, as well as between the most abundant short-chain fatty acids present in the colon, including acetate, butyrate, and propionate (Brasili et al., 2019).

\section{Pulp}

\section{Antioxidant activity}

The radical scavenging ability of eight citrus pulp methanol extracts, namely Citrus sinensis cv. Hamlin, cv. red blood, cv. succuri, Citrus limetta mosambi, Citrus reticulata tangerine, Citrus paradise macfed, Citrus aurantium L., and Citrus jambhiri lush (Table 2), were investigated (Rehman et al., 2020a). Among these, Citrus sinensis cv. succuri had the highest values (65.3\%). Costanzo et al. (2020) compared the antioxidant potential of powdered Citrus reticulata, Citrus japonica, and 


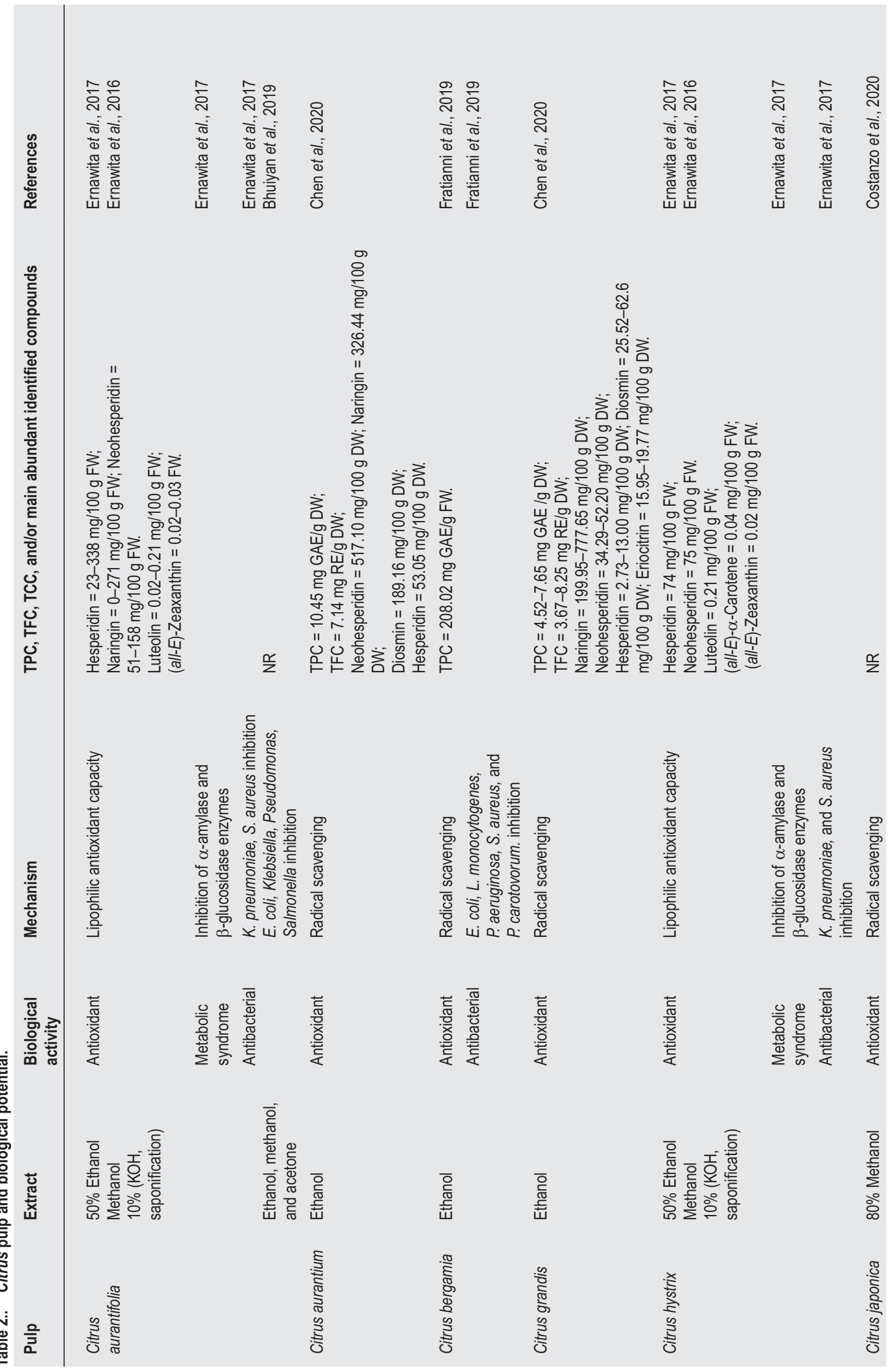



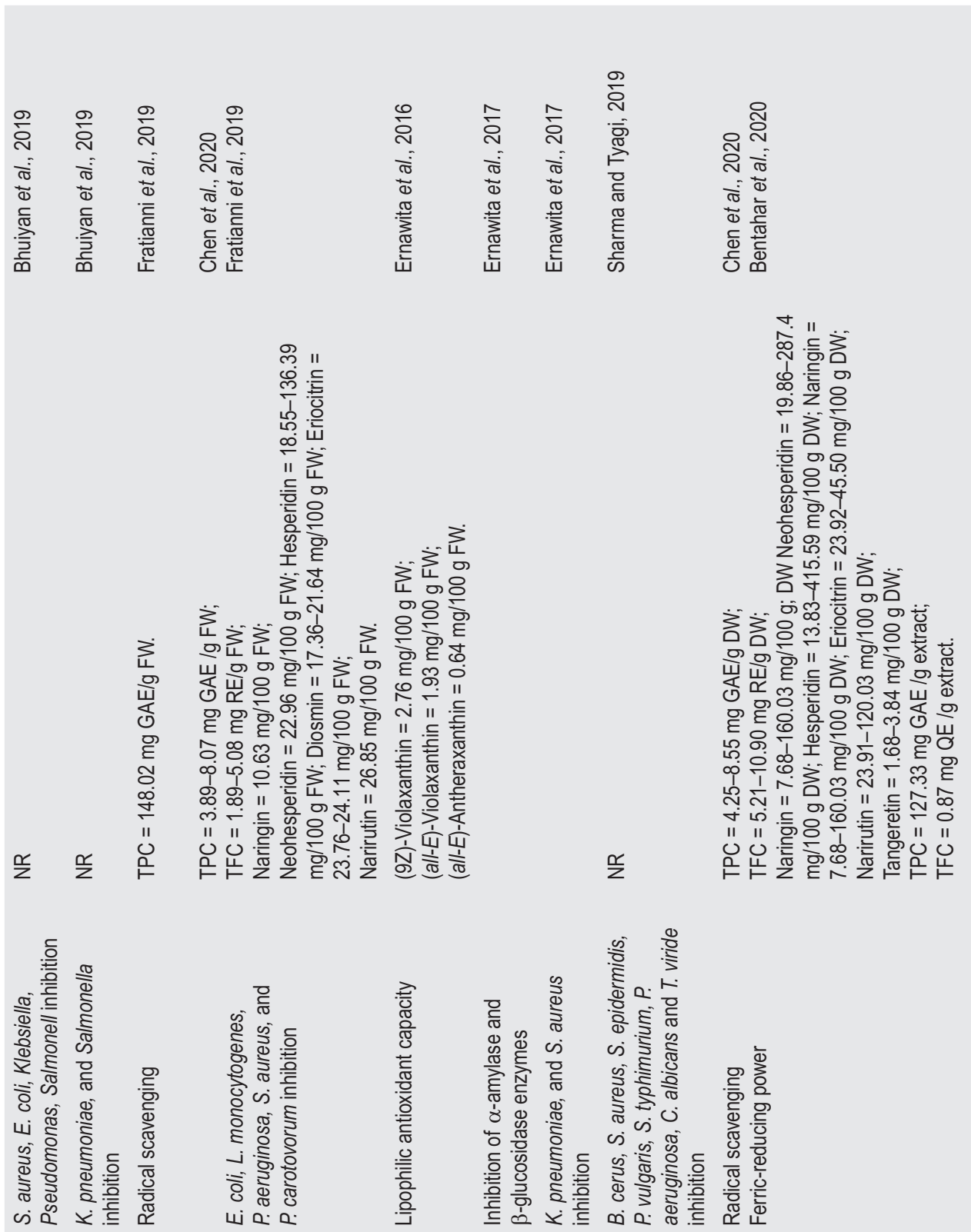

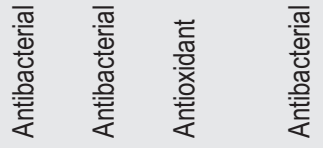

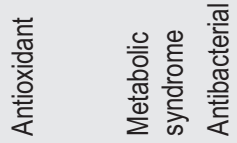

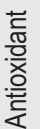
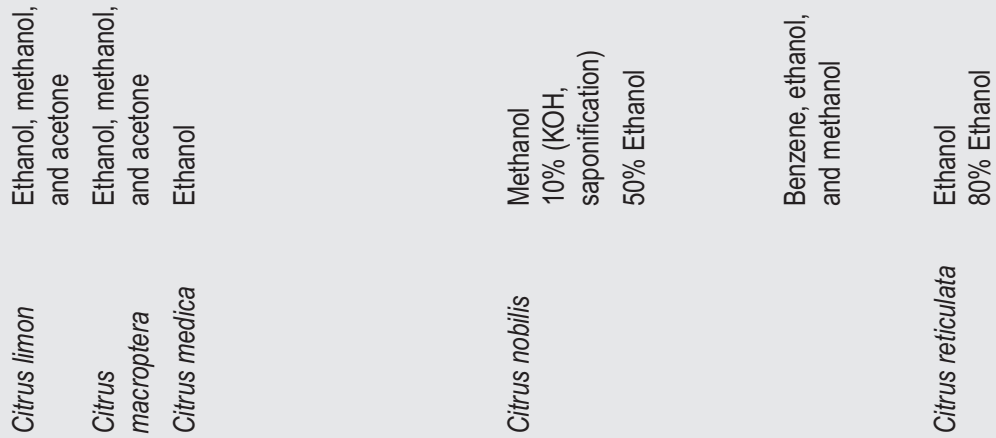


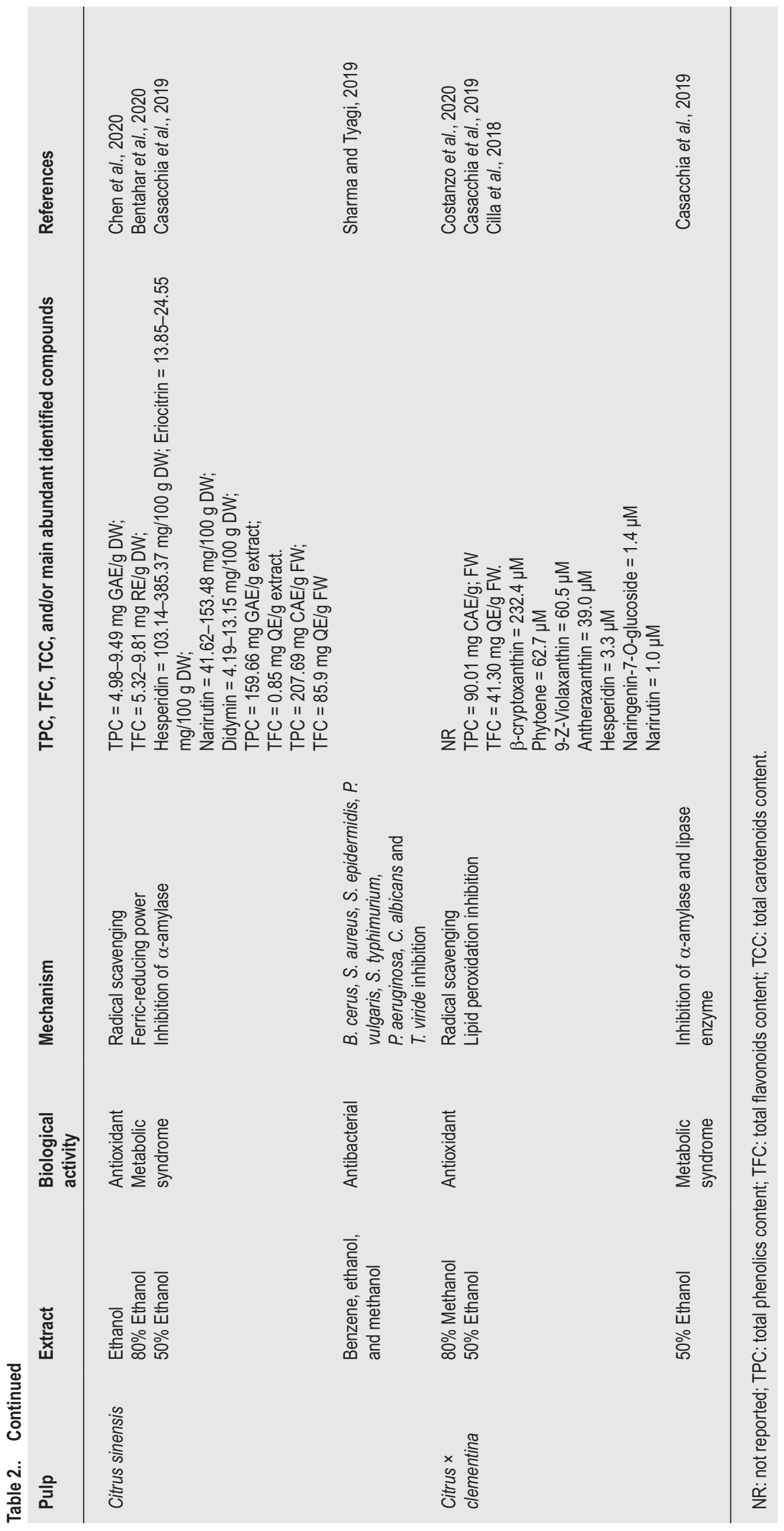


citrus $\times$ clementina tissue. In the citrus $\times$ clementina pulp extracts, the total antioxidant capacity (TAC) was found to be three-fold higher $(7.1 \mathrm{mmol} \mathrm{TE} / \mathrm{mg}$ fresh weight $[\mathrm{FW}])$ compared to Citrus reticulata $(2.6 \mathrm{mmol}$ TE/mg FW) and six-fold higher compared to Citrus japonica (1.2 mmol TE/mg FW). Similarly, Citrus sinensis and Citrus reticulata fruits possessed good antioxidant activity studied by the hydroxyl radical scavenging activity and reducing power capacity methods (Bentahar et al., 2020).

Fratianni et al. (2019) indicated that Citrus bergamia and Citrus medica cv. Salò homogenized pulp extracts exhibited the highest antioxidant potential compared to Citrus medica. Previously, the in vitro lipophilic antioxidant capacity of seven citrus pulp extracts was reported (Ernawita et al., 2017). Among them, jeruk makin (Citrus aurantium) showed the highest antioxidant capacity $(19.5 \mu \mathrm{mol} \mathrm{TE} / 100 \mathrm{~g})$, followed by jeruk calung pulp extracts (Citrus aurantium) and jeruk nipis (Citrus aurantiifolia) (10.7 and $10.6 \mu \mathrm{mol} \alpha-\mathrm{TE} / 100 \mathrm{~g}$, respectively). Previously, in vivo studies have reported that Citrus macroptera ethanol pulp extract possessed a significant lipid-lowering activity and a significant diminution of lipid peroxidation in liver and kidney tissues was observed (Paul et al., 2015). The protective effect against oxidative stress of pulp bio-accessible fractions of oranges from Navel and Cara oranges cultivars as well as clementine was also demonstrated (Cilla et al., 2018). These fractions act by pre-serving cell viability, correct cell cycle progression, mitochondrial membrane potential, and diminishing ROS level and lipid peroxidation.

Recently, the effect of dried orange pulp on antioxidants level in the plasma was evaluated (Allam Sabbah et al., 2020). Results demonstrated that the value of total antioxidant capacity, as a biomarker of oxidative stress, was gradually increased (ranged from 0.420 to $0.433 \mathrm{~mm} / \mathrm{L}$ ) by increasing the level of dried orange pulp supplementation $(25,50$, and $75 \%)$. Additionally, a reduction of total lipids values was observed.

\section{Metabolic syndrome}

The $\alpha$-amylase inhibition activity of seven citrus pulp extracts was analyzed by Ernawita et al. (2017). Makin and jeruk nipis pulp extracts exhibited the lowest $\mathrm{IC}_{50}$ values (18.8 and $19.4 \mathrm{mg} / \mathrm{mL}$, respectively), while calung extract possessed less activity $\left(\mathrm{IC}_{50}=56.2 \mathrm{mg} / \mathrm{mL}\right)$.

Oral administration of Citrus hystrix and Citrus maxima pulp extracts $(5,50,300$, and $2,000 \mathrm{mg} / \mathrm{kg}$ body weight (BW) in streptozotocin (STZ)-induced diabetic rats for 14 days was able to reduce blood glucose, TG level, and serum cholesterol. Additionally, the HDL-cholesterol level was found to improve (Arumugam et al., 2019).

The lipase inhibitor activity of citrus pulp extracts was reported by Casacchia et al. (2019), founding the $\mathrm{IC}_{50}$ values of 86.30, 105.90, and $67.20 \mathrm{mg} / \mathrm{mL}$, respectively, for Citrus clementina, Citrus sinensis, and their hybrid called Tacle ${ }^{\circledR}$.

\section{Antibacterial activity}

Citrus bergamia, Citrus medica, and Citrus medica cv. Salò pulp extracts were described as antibacterial agents against Escherichia coli, Listeria monocytogenes, Pseudomonas aeruginosa, S. aureus, and Pectobacterium carotovorum (Fratianni et al., 2019). The antibacterial activity of various citrus pulp extracts was also reported by Ernawita et al. (2017). Among them, jeruk makin and jeruk nipis showed the highest inhibitor capacity against Klebsiella pneumoniae $\left(\mathrm{IC}_{50}=3.3\right.$ and 4.1 $\mathrm{mg} / \mathrm{mL}$ ) and $S$. aureus $\left(\mathrm{IC}_{50}=2.6\right.$ and $3.1 \mathrm{mg} / \mathrm{mL}$ ). In addition, Citrus limon, Citrus aurantifolia, and Citrus macroptera pulp extracts were screened for antimicrobial activity against $S$. aureus, E. coli, Klebsiella sp., Pseudomonas sp., and Salmonella sp. (Bhuiyan et al., 2019). Citrus macroptera, a taxonomic synonym of Citrus hystrix (kaffir lime) known for its antioxidant, nutritious, and therapeutic uses (Paul et al., 2017) ethanol extracts exhibited the highest zone of inhibition (14 $\mathrm{mm})$ against Klebsiella sp. while Citrus aurantifolia methanol extract showed the highest zone of inhibition $(8 \mathrm{~mm})$ against Salmonella sp.

\section{Citrus seed}

\section{Antioxidant potential}

Bitter orange, blonde orange, sweet orange, lemon, and mandarin seed ultrasound methanol extracts (Table 3) were investigated for their antioxidant ability but no differences were found in the radical scavenging activity (Falcinelli et al., 2020). Conversely, Costanzo et al. (2020) demonstrated that powered Citrus reticulata seed extract tissue showed the highest antioxidant capacity (55.6 mmol TE/mg FW) compared to Citrus japonica seed extract tissue $(3.2 \mathrm{mmol} \mathrm{TE} / \mathrm{mg} \mathrm{FW})$. The radical scavenging ability of eight citrus seed extracts were investigated (Rehman et al., 2020a). Among them, Citrus jambhiri lush, Citrus sinensis cv. red blood, and Citrus reticulata tangerine possessed the highest activity (54.3, 53.6, and 53.3\%, respectively). Previously, the following ranking of radical scavenging effect was demonstrated: lemon seeds extract > orange seeds extract $>$ mandarin seeds extract (İnan et al., 2018). 
Table 3. Bioactivity of Citrus seed.

\begin{tabular}{|c|c|c|c|c|c|}
\hline Seed & Extract & $\begin{array}{l}\text { Biological } \\
\text { activity }\end{array}$ & Mechanism & $\begin{array}{l}\text { TPC, TFC, TCC, and/or } \\
\text { main abundant identified } \\
\text { compounds }\end{array}$ & References \\
\hline \multirow[t]{3}{*}{ Citrus aurantium } & Methanol & Antioxidant & Radical scavenging & $\mathrm{TPC}=2.5 \mathrm{GAE} / \mathrm{g} \mathrm{DW}$ & Falcinelli et al., 2020 \\
\hline & & Anti-inflammatory & Anti-edematogenic effects & & \\
\hline & & Antibacterial & $\begin{array}{l}\text { Proteus and Pseudomonas } \\
\text { inhibition }\end{array}$ & NR & Aladekoyi et al., 2016 \\
\hline Citrus aurantium & Methanol & Antioxidant & Radical scavenging & $\begin{array}{l}\text { TPC }=107 \mathrm{mg} / 100 \mathrm{~g} \\
\mathrm{TFC}=20.8 \mathrm{mg} / 100 \mathrm{~g}\end{array}$ & Rehman et al., 2020c \\
\hline Citrus jambhiri & Methanol & Antioxidant & Radical scavenging & $\mathrm{TCC}=-25 \mathrm{mg} / \mathrm{g} \mathrm{FW}$ & Costanzo et al., 2020 \\
\hline Citrus jambhiri & Methanol & Antioxidant & Radical scavenging & $\begin{array}{l}\mathrm{TPC}=129 \mathrm{mg} / 100 \mathrm{~g} \\
\mathrm{TFC}=22.8 \mathrm{mg} / 100 \mathrm{~g} .\end{array}$ & Rehman et al., 2020c \\
\hline Citrus junos & & Anti-inflammatory & Inhibition of NO production & Not reported & Ko et al., 2020 \\
\hline \multirow[t]{3}{*}{ Citrus limon } & Methanol & Antioxidant & $\begin{array}{l}\text { Radical scavenging } \\
\text { Restoration of antioxidant } \\
\text { defense system }\end{array}$ & $\begin{array}{l}\mathrm{TPC}=1.2 \mathrm{GAE} / \mathrm{g} \mathrm{DW} \\
\mathrm{TPC}=152.70-212.30 \mathrm{mg} \\
\mathrm{GAE} / \mathrm{kg}\end{array}$ & $\begin{array}{l}\text { Falcinelli et al., } 2020 \\
\text { Inan et al., } 2017\end{array}$ \\
\hline & & $\begin{array}{l}\text { Metabolic } \\
\text { syndrome }\end{array}$ & $\begin{array}{l}\text { Reduction of glucose and lipid } \\
\text { levels }\end{array}$ & NR & Demir and Celik, 2019 \\
\hline & & Antibacterial & $\begin{array}{l}\text { Klebsiella, Proteus and } \\
\text { Pseudomonas inhibition }\end{array}$ & NR & Aladekoyi et al., 2016 \\
\hline Citrus limetta & Methanol & Antioxidant & Radical scavenging & $\begin{array}{l}\text { TPC = } 99.1 \mathrm{mg} / 100 \mathrm{~g} \\
\text { TFC = } 19.37 \mathrm{mg} / 100 \mathrm{~g} .\end{array}$ & Rehman et al., 2020c \\
\hline Citrus maxima & Ethanol & Antibacterial & $\begin{array}{l}\text { S. aureus, E. coli, and } \\
\text { B. subtilis inhibition }\end{array}$ & TFC = $1602.740 \mathrm{mg} / \mathrm{kg}$ & Sahlan et al., 2018 \\
\hline Citrus paradise & Ethanol & Antibacterial & $\begin{array}{l}\text { S. aureus, E. coli, } \\
\text { S. typhimurium, S. enteritidis, } \\
\text { P. aeruginosa, K. pneumoniae, } \\
\text { Citrus utilis, and B. cereus } \\
\text { inhibition }\end{array}$ & $\mathrm{TFC}=483.562 \mathrm{mg} / \mathrm{kg}$. & Sahlan et al., 2018 \\
\hline \multirow[t]{2}{*}{ Citrus reticulata } & Methanol & Antioxidant & Radical scavenging & $\begin{array}{l}\mathrm{TPC}=112 \mathrm{mg} / 100 \mathrm{~g} \\
\mathrm{TFC}=21.5 \mathrm{mg} / 100 \mathrm{~g} .\end{array}$ & Rehman et al., 2020c \\
\hline & Methanol & & & $\begin{array}{l}\text { TPC }=2.4 \mathrm{GAE} / \mathrm{g} \mathrm{DW} . \\
\mathrm{TCC}=-10 \mathrm{mg} / \mathrm{g} \mathrm{FW} . \\
\text { TPC }=152.70-212.30 \mathrm{mg} \\
\text { GAE } / \mathrm{kg} .\end{array}$ & $\begin{array}{l}\text { Falcinelli et al., } 2020 \\
\text { Costanzo et al., } 2020 \\
\text { İnan et al., } 2017\end{array}$ \\
\hline Citrus sinensis & Methanol & Antioxidant & Radical scavenging & $\begin{array}{l}\text { TPC }=101-118 \mathrm{mg} / 100 \mathrm{~g} ; \\
\text { TFC }=20.1-22.60 \mathrm{mg} / 100 \mathrm{~g} .\end{array}$ & Rehman et al., 2020c \\
\hline \multirow[t]{3}{*}{ Citrus sinensis } & Methanol & & & $\mathrm{TPC}=1.3 \mathrm{GAE} / \mathrm{g} \mathrm{DW}$ & Falcinelli et al., 2020 \\
\hline & $n$-Hexane & $\begin{array}{l}\text { Metabolic } \\
\text { syndrome }\end{array}$ & $\begin{array}{l}\text { Reduction of fasting blood } \\
\text { glucose, serum TG, serum } \\
\text { cholesterol, HDL }\end{array}$ & NR & Chilaka et al., 2015 \\
\hline & Ethanol & Antibacterial & $\begin{array}{l}\text { S. aureus, Enterococcus } \\
\text { faecalis, } P \text {. aeruginosa, E. coli } \\
\text { and Citrus albicans inhibition }\end{array}$ & NR & Oikeh et al., 2020 \\
\hline
\end{tabular}

NR: not reported; TPC: total phenolics content; TFC: total flavonoids content; TCC: total carotenoids content.

\section{Metabolic Syndrome}

It has been reported recently that lemon seed extract could prevent diabetic complications due to reduction in glucose and lipid profile levels and restoration of antioxidant defense system (Demir and Celik, 2019). Previously, a reduction of blood glucose in alloxan-induced diabetic rats was observed after treatment with emulsified sweet orange seed oil (1000 mg/kg BW). In addition, this seed oil improved sugar and lipid profile with reduction of serum TG, cholesterol, and increased HDL-cholesterol in diabetic rats (Chilaka et al., 2015). 


\section{Anti-inflammatory effects}

Nitric oxide (NO) is recognized as a mediator and regulator in pathological reactions, especially in acute inflammatory responses (Terao, 2009). The development of substances to prevent the overproduction of NO has become a new research target to treat chronic inflammatory diseases. Ko et al. (2020) reported the anti-inflammatory effect of Citrus junos seed oil. NO production was suppressed by $53 \%$ at a concentration of $0.05 \%$ that does not show cytotoxicity. The possible anti-inflammatory and antinociceptive activity of Citrus aurantium seed oil, obtained by using Soxhlet apparatus with $n$-hexane, was evaluated by using formalin-induced paw licking, edema, and myeloperoxidase activity assessment (Azadeh et al., 2019). The results showed that seed oil exhibited anti-inflammatory properties in the first and second phases of formalin test, antiedematogenic effects but exerted no effects on myeloperoxidase activity.

\section{Antibacterial potential}

Recently, the antibacterial activities of Citrus sinensis seed oil, obtained by Soxhlet apparatus using $n$-hexane as solvent and ethanol extract, was studied (Oikeh et al., 2020). The results showed that the non-oil extract had better antibacterial activity against $S$. aureus, Enterococcus faecalis, and E. coli. On the contrary, the seed oil had better activity against Salmonella spp. Similar susceptibility was found for $P$. aeruginosa. Previously, it was demonstrated that Citrus sinensis seed oil obtained by Soxhlet apparatus using $n$-hexane as solvent possessed antibacterial activity against $S$. aureus and Candida albicans (Olabanji et al., 2016). Buket et al. (2018) also reported that the lemon, orange, and grapefruit cold-pressed seed oil had inhibition zones ranging from 6.62 to $11.00 \mathrm{~mm}$ against pathogenic bacteria such as S. aureus, E. coli, S. typhimurium, Salmonella enteritidis, P. aeruginosa, K. pneumoniae, Candida utilis, and Bacillus cereus Holl. The antimicrobial and antifungal activities of aqueous and ethanolic grapefruit seed extracts were confirmed against $S$. aureus, E. faecalis, Bacillus subtilis, E. coli, P. aeruginosa, K. pneumoniae, and C. albicans (Eryilmaz et al., 2018). The ethanolic extract of pomelo seeds also gives positive results with growth-inhibition effect on Bacillus subtilis, S. aureus, and E. coli (Sahlan et al., 2018). Oil extracted from lemon, lime, and bitter orange seeds possessed different antimicrobial potential. Similar activity was found for Staphylococcus, but only lemon seed oil has activity against Klebsiella and the highest zone of inhibition against Proteus, while bitter orange has a maximum zone of inhibition $(0.25 \mathrm{~mm}$ ) against Pseudomonas (Aladekoyi et al., 2016).

\section{Citrus peels}

\section{Antioxidant effects}

Recently, the antioxidant potential of citrus $\times$ clementina peel extracts, collected from different areas of Calabria and obtained by using different methodologies, was studied (Leporini et al., 2020a). Results demonstrated that sample from Cetraro obtained by ultrasound extraction in ethanol possessed the highest antioxidant activity (Table 4). Interestingly, the citrus $\times$ clementina juice enriched with this extract $(20 \% \mathrm{v} / \mathrm{w})$ increased its antioxidant potential. Similarly, Pereira et al. (2020) reported the increase of beer antioxidant activity after addition of orange peels extract.

Huang et al. (2020) compared the antioxidant ability of eight citrus peel extracts: grapefruit, pomelo, kumquat, mandarin, ponkan, tangerine, lemon, and sweet orange. The most active samples were ponkan extract in DPPH and FRAP assays (386.25 and 466.14 $\mu \mathrm{mol} \mathrm{TE} / \mathrm{g}$ of extract, respectively), tangerine extract in ABTS assay $(689.43 \mu \mathrm{mol}$ $\mathrm{TE} / \mathrm{g})$, and pomelo in ORAC assay $(1964.0 \mu \mathrm{mol} \mathrm{TE} / \mathrm{g})$. An inhibition of $92.87 \%$ was reported for Citrus hystrix peels extract against DPPH radical (Ramli et al., 2020).

Citrus sinensis and Citrus aurantium peels' extracts were investigated as potent antioxidant agents against lipid peroxidation (Rafiq et al., 2018). Furthermore, the bergamot extract showed a higher ABTS radical inhibition with a value of $136.3 \mathrm{mmol} \mathrm{TE} / \mathrm{g}$ dry weight (DW). The capacity of Citrus medica Diamante hydroalcoholic peels extract to inhibit both DPPH and ABTS radicals $\left(\mathrm{IC}_{50}=\right.$ 0.81 and $3.48 \mathrm{mg} / \mathrm{mL}$, respectively) was also demonstrated by Menichini et al. (2016). In $\beta$-carotene, this extract exhibited an $\mathrm{IC}_{50}$ value of $0.23 \mathrm{mg} / \mathrm{mL}$. Da Silva et al. (2018) studied the antioxidant potential of pomelo peels cv. Toranja Buraram in $n$-hexane, ethyl acetate, acetone, ethanol, methanol, and methanol:water (80:20). The ethyl acetate and methanolic extracts presented the highest antioxidant activity in vitro by DPPH $\left(\mathrm{IC}_{50}=298.3\right.$ and $303.8 \mu \mathrm{g} / \mathrm{mL}$, respectively), ABTS assay $\left(\mathrm{IC}_{50}=298.2\right.$ and $296.4 \mu \mathrm{g} / \mathrm{mL}$, respectively), and FRAP $\left(\mathrm{IC}_{50}=234.6\right.$ and $398.1 \mu \mathrm{g} / \mathrm{mL}$, respectively).

Long et al. (2021) evaluated the antioxidant effects of ethanol extract and its three subfractions-petroleum ether, ethyl acetate, and water extracts-of Citrus sinensis cv. Gannanzao peels. The ethyl acetate extract exhibited the best antioxidant potential compared to four extracts in all antioxidant assays with the $\mathrm{IC}_{50}$ values of $38.33 \mathrm{mg} / \mathrm{mL}$ and $8.47 \mathrm{mg} / \mathrm{mL}$ in DPPH and ABTS tests, respectively, and value of $21.54 \mathrm{mM}$ Trolox equivalents (TE)/mg DW in FRAP assay. The results correspond to those reported by Guo et al. (2020) for Citrus sinensis cv. Newhall peels extract. 


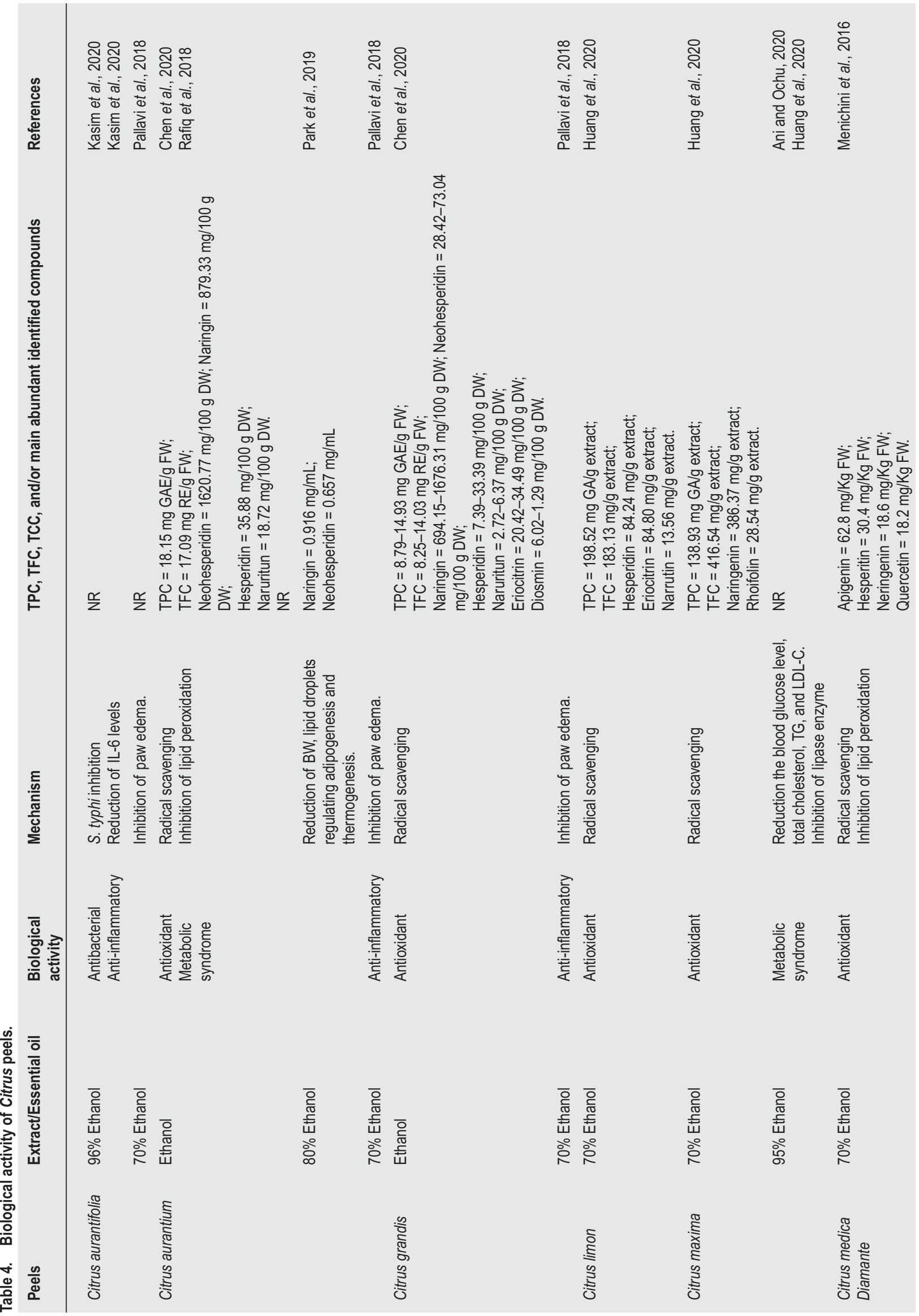




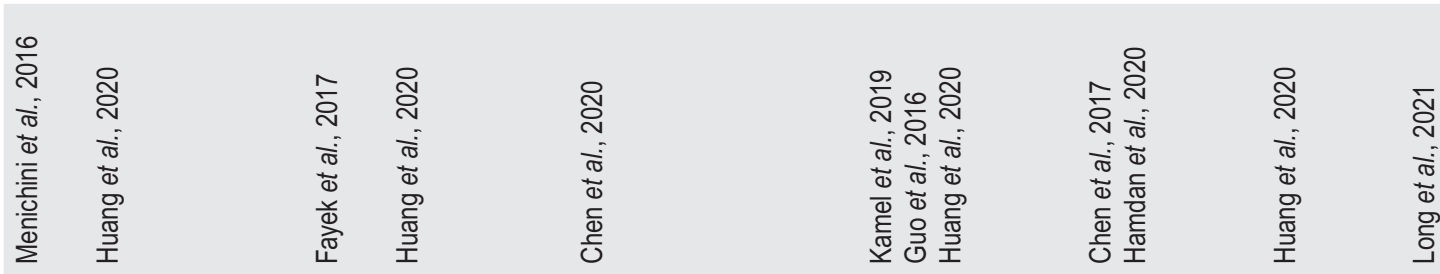

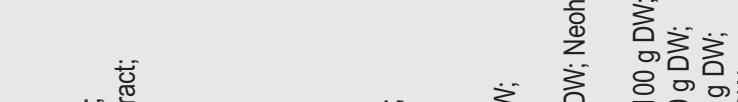

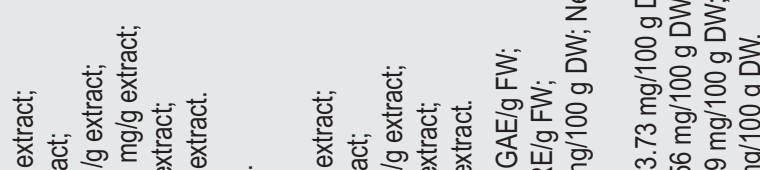
ब

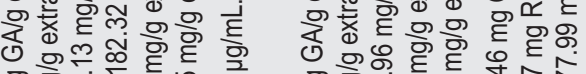

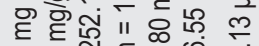

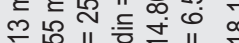

핱ㅎㅇ을

लिं 융 के

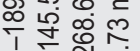

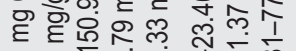
돈ํำ

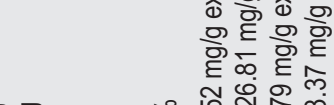

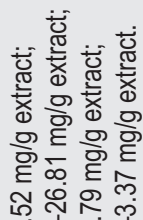

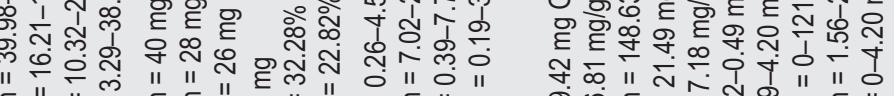

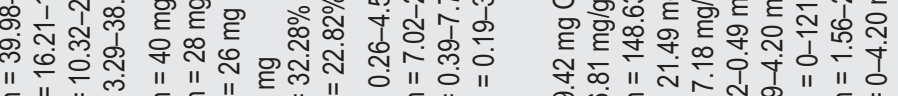

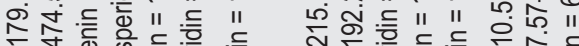

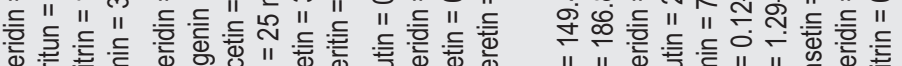

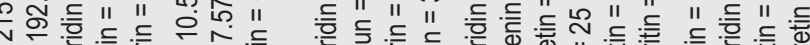
"II

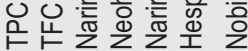

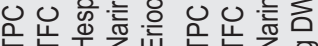

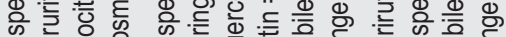
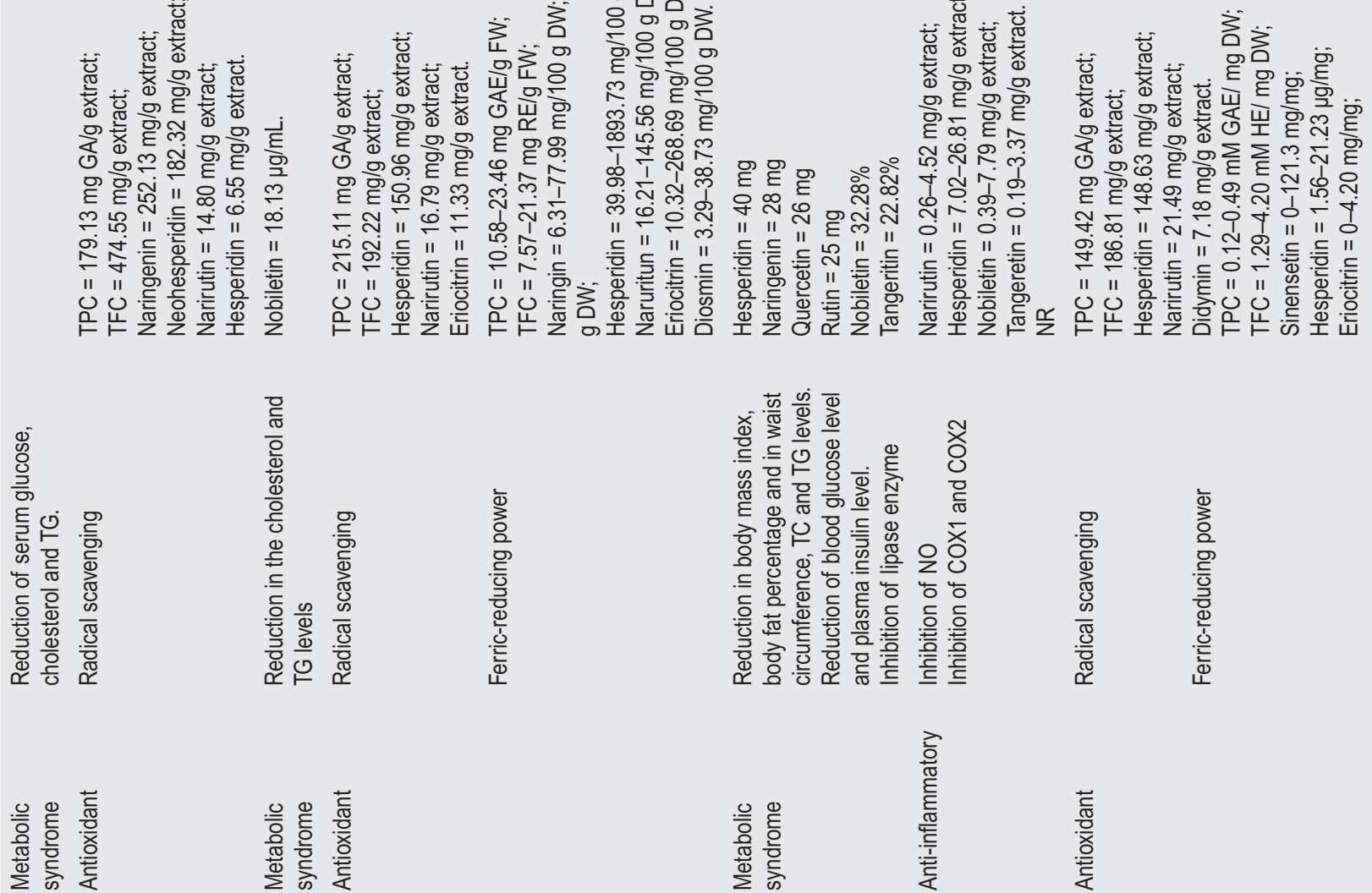

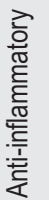

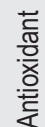
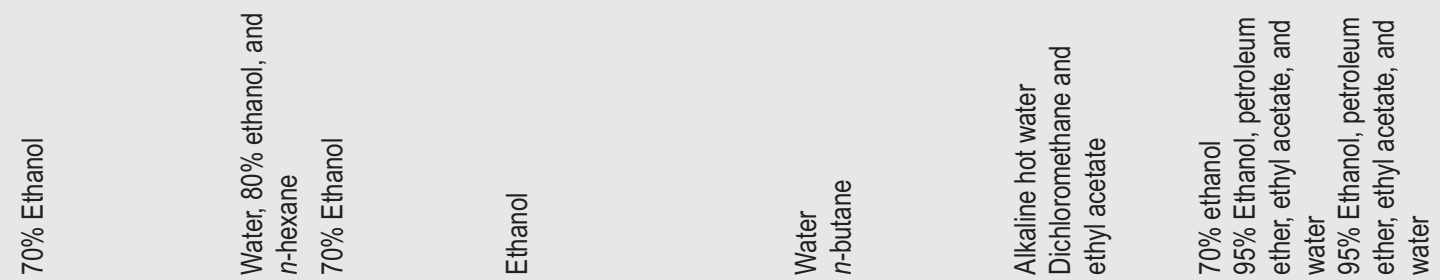

$\frac{0}{0}$
$\frac{5}{2}$
$\frac{0}{2}$
$\frac{0}{0}$
$\frac{1}{2}$

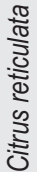




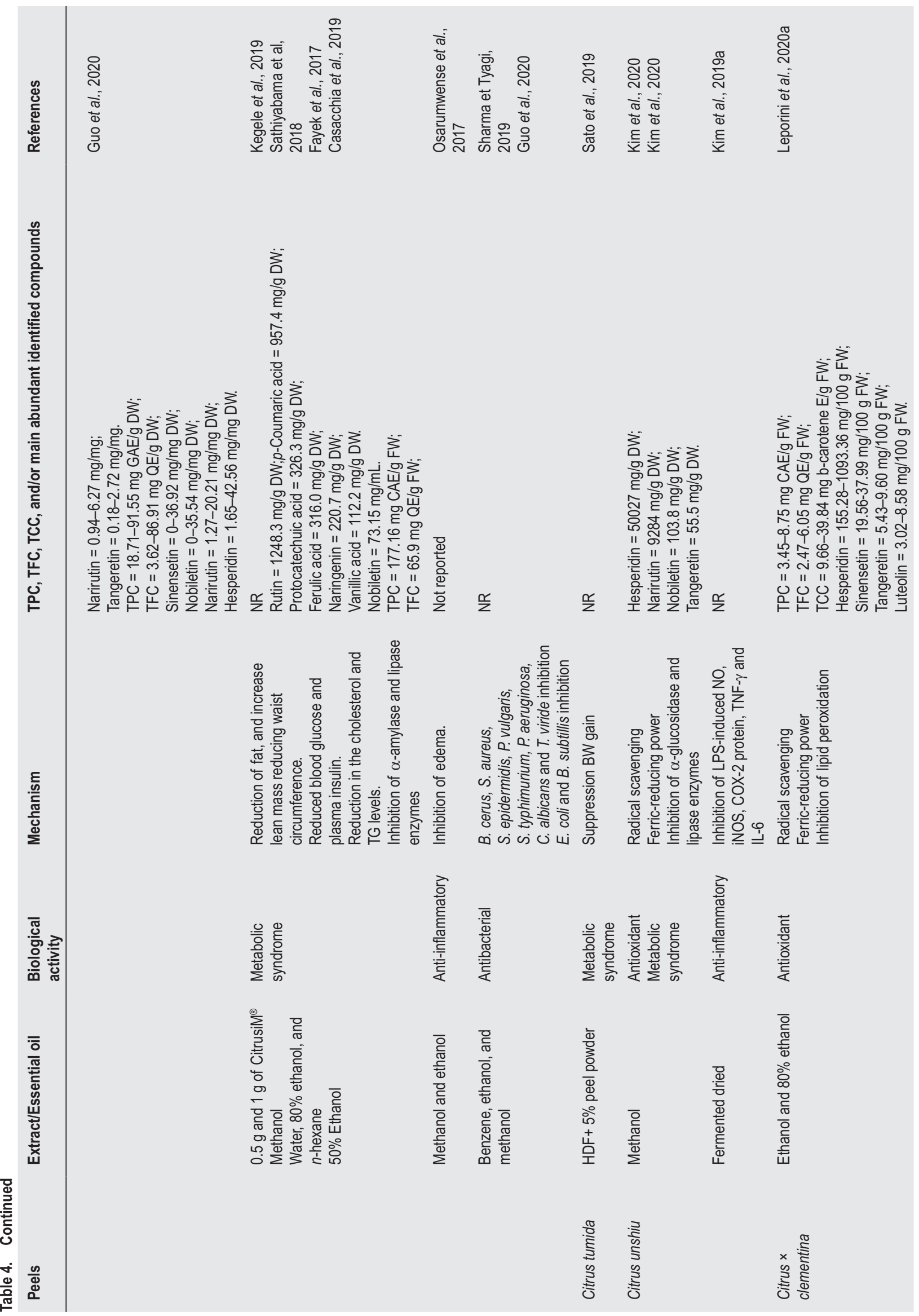




\begin{tabular}{|c|c|c|c|c|c|c|c|c|}
\hline 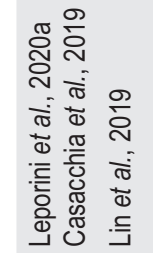 & 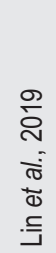 & 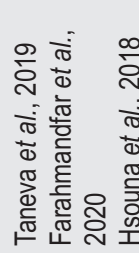 & 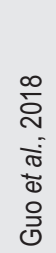 & 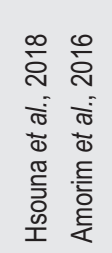 & 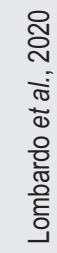 & 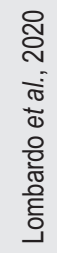 & 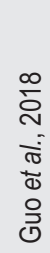 & 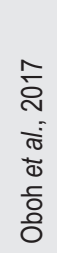 \\
\hline
\end{tabular}

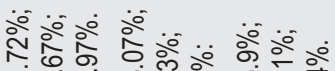

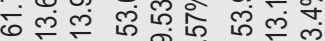
"1" II "

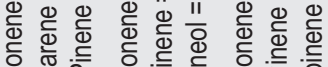

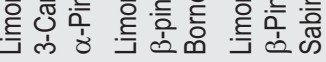

崖荒

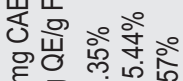

ฟิ่

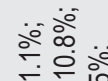

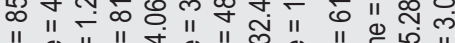

11"

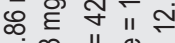

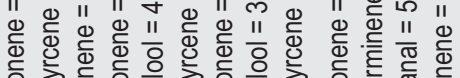

Q

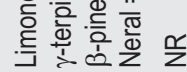
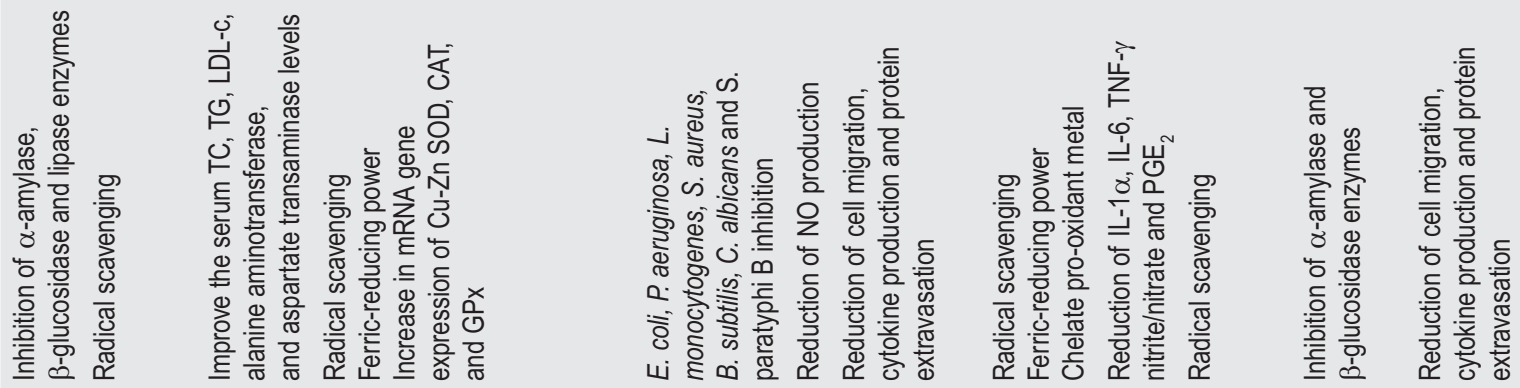

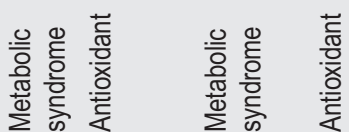

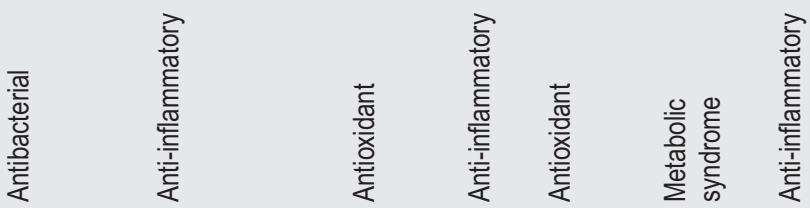

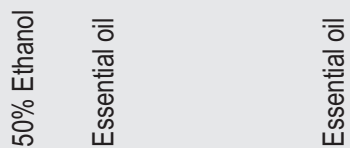
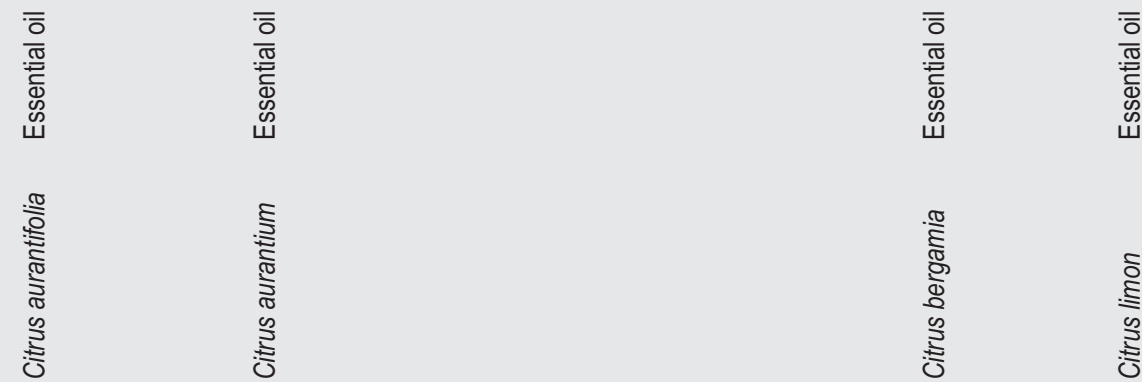

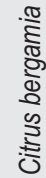

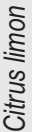




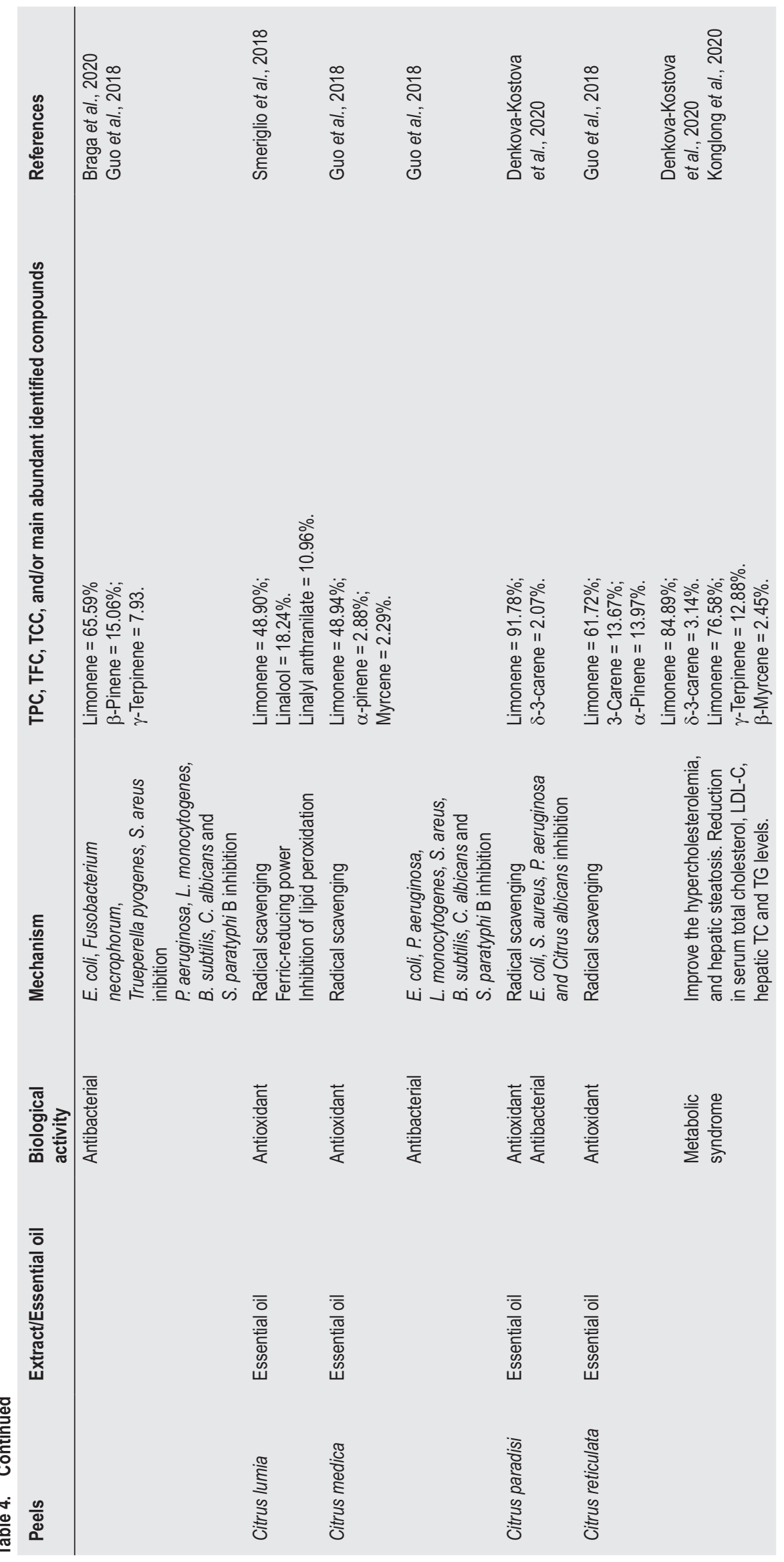




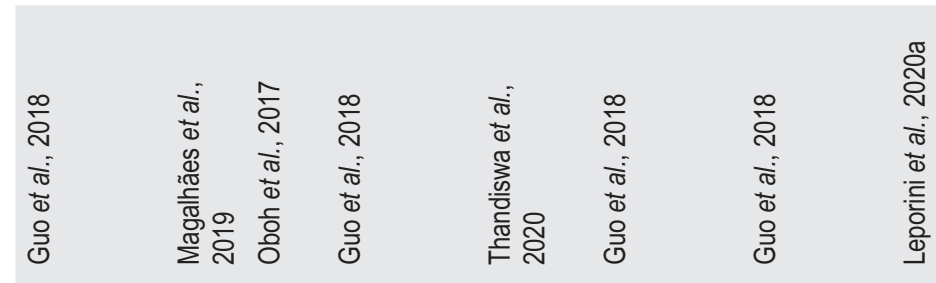
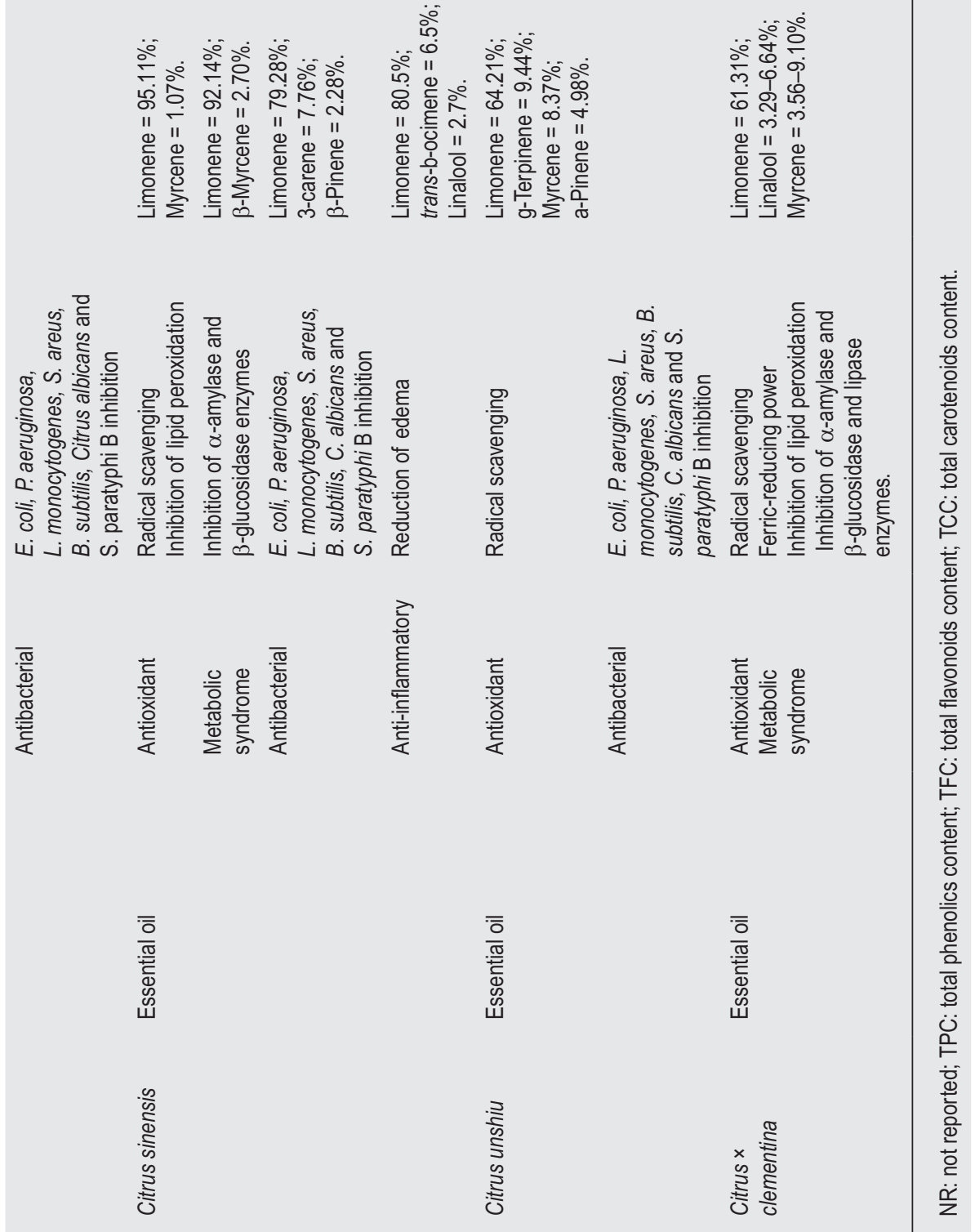
Recently, the antioxidant activities of Citrus reticulata, Citrus paradise, and Citrus lemon peels' essential oils were reported (Denkova-Kostova et al., 2020). The radical scavenging potential on DPPH radical revealed that the highest percentage of inhibition was found in the grapefruit (87.5\%), followed by lemon and tangeretine with values of $86.1 \%$ and $78.0 \%$, respectively. The antioxidant potential of grapefruit, lemon, mandarin, and orange essential oils was also investigated by Raspo et al. (2020). Mandarin exhibited the highest activity in ABTS test, grapefruits exhibited the highest activity in FRAP test, and lemon exhibited the highest activity in DPPH test.

Citrus lumia essential oil showed a strong antioxidant activity in different assays, with the following order of potency (expressed as $\left.\mathrm{IC}_{50}\right)$ : $\beta$-carotene $(22 \mu \mathrm{g} / \mathrm{mL})>$ ORAC $(46 \mu \mathrm{g} / \mathrm{mL})>\operatorname{DPPH}(104 \mu \mathrm{g} / \mathrm{mL})>$ Folin-Ciocalteu $(181 \mu \mathrm{g} / \mathrm{mL})>$ FRAP $(202 \mu \mathrm{g} / \mathrm{mL})>$ Trolox equivalent antioxidant capacity (TEAC) $(233 \mu \mathrm{g} / \mathrm{mL})$ (Smeriglio et al., 2018). For Citrus aurantium peels' essential oil, an inhibition percentage of $88.1 \%$ against DPPH radical was observed (Tevena et al., 2019). A lower activity was reported for bitter orange with an inhibition percentage of $31.33 \%$ (Farahmandfar et al., 2020).

\section{Metabolic syndrome}

Recently, the effects of Citrus reticulata peels' water extract $(800 \mathrm{mg})$ administered to obese adolescents were analyzed (Kamel et al., 2019). In this clinical trial, the extract showed a reduction in BMI, body fat percentage, and waist circumference after 4 and 8 weeks of supplementation. Additionally, a reduction of total cholesterol (TC) and TG levels was observed. Huang et al. (2020) compared the in vitro anti-obesity ability of grapefruit, pomelo, kumquat, mandarin, ponkan, tangerine, lemon, and sweet orange peels' extracts. Among them, the most active sample was sweet orange, followed by tangerine and ponkan with the $\mathrm{IC}_{50}$ values of $87.25,109.44$, and $126.62 \mathrm{mg} / \mathrm{mL}$, respectively, against lipase enzymes. Also, for Citrus unshiu peels' water extract, an inhibitor effect was reported for lipase activity $\left(\mathrm{IC}_{50}=507.01 \mu \mathrm{g} / \mathrm{mL}\right)$ (Kim et al., 2016). Better results were observed for citrus $\times$ clementina peels extract with values in the range of 112.06-191.91 mg/mL (Leporini et al., 2020a). In particular, peels extract from Cetraro, obtained by ultrasound extraction EtOH, exhibited the strongest hypolipidemic activity. Additionally, this extract increased the hypolipidemic activity of citrus $\times$ clementina juice when added at a concentration of $20 \%$ (w/v). Oboh et al. (2017) reported that the lemon peels' essential oil exhibited stronger inhibitory activity on $\alpha$-amylase and $\alpha$-glucosidase activities $\left(\mathrm{IC}_{50}\right.$ values of 8.16 and $7.56 \mu \mathrm{g} / \mathrm{mL}$, respectively) compared to orange peels' essential oil $\left(\mathrm{IC}_{50}\right.$ values of 11.51 and $11.53 \mu \mathrm{g} / \mathrm{mL}$, respectively).
The effectiveness of Citrus maxima peels ethanol extract was suggested recently in the management of diabetes (Ani and Ochu, 2020). Indeed, the administration of this extract $(600 \mathrm{mg} / \mathrm{kg} \mathrm{BW} /$ day) for 14 days decreased the blood glucose level (70.17\%), TA (30.86\%), TG (10.58\%), and LDL-cholesterol (10.20\%). Additionally, an increase of HDL-cholesterol (4.43\%) was observed. Dietary ingestion of Citrus tumida Hort. ex Tanaka peels powder (5\% w/w) suppressed BW gain by decreasing epidydimal, perirenal, and subcutaneous fat weights (Sato et al., 2019). A similar effect, that is a significant decrease of BW, was observed for Citrus aurantium extract $(100 \mathrm{mg} / \mathrm{kg} /$ day) administered for 8 weeks. Additionally, the same treatment in 3T3-L1 adipocytes determined a reduction of lipid droplets regulating adipogenesis and thermogenesis via AMP-activated protein kinase alpha (AMPK $\alpha$ ) pathway (Park et al., 2019). Kegele et al. (2019) investigated the effects of CitrusiM ${ }^{\circ}$ (Citrus sinensis dried extract) on body composition: percentage of lean mass and percentage of fat mass. This extract determined a significant reduction of fat, and increase in lean mass reducing waist circumference after a dose of 0.5 or $1 \mathrm{~g} /$ day. Similarly, the obese mice treated with supplementation of $0.25 \%$ and $0.5 \%$ of Citrus reticulata extract in food for 12 weeks exhibited a reduction of $21 \%$ and $34 \%$ in BW, respectively (Guo et al., 2016). This effect was probably due to the action of citrus phytochemicals on metabolism of glucose and fatty acids.

Administration of Citrus sinensis methanol peels extract at doses of 50 and $100 \mathrm{mg} / \mathrm{kg}$ in diabetic rats reduced fasting blood glucose by $56.1 \%$ and $55.7 \%$, respectively, and plasma insulin levels by $22.9 \%$ and $32.7 \%$, respectively (Sathiyabama et al., 2018). Citrus medica Diamante hydroalcoholic peels extract was tested in $\mathrm{db} / \mathrm{db}$ mouse model for leptin deficiency. This mutation confers susceptibility to obesity, insulin resistance, and T2DM. Administration of $600 \mathrm{mg} / \mathrm{kg}$ of Diamante peels extract significantly decreased the serum glucose level (Menichini et al., 2016). This extract was rich in phenolic compounds that are known to posses several actions to improve glucose tolerance as reported below. The in vivo reduction of blood glucose and plasma insulin levels was demonstrated for both Citrus reticulata and Citrus sudachi peels extract (Guo et al., 2016; Kobayashi et al., 2017). In particular, Citrus sudachi exerted its effect via reduction of TNF- $\alpha$ mRNA expression.

Literature showed that citrus genus was able to counteract the effect of high cholesterol level (Favela-Hernández et al., 2016). Recently, the hypocholesterolemic effects of mandarin peels' aqueous and $n$-hexane extracts was demonstrated (Fayek et al., 2017). The results showed that these extracts decrease the cholesterol level by $59.3 \%$ and $56.8 \%$, respectively. A reduction in cholesterol and TG levels was also observed with Citrus medica cv. 
Diamante peels' hydroalcoholic extract of (300 and 600 $\mathrm{mg} / \mathrm{kg} /$ day) administered in Zucker diabetic rats for 4 weeks (Menichini et al., 2016). Successively, Konglong et al. (2020) demonstrated that Citrus reticulata peels' essential oil was able to ameliorate hypercholesterolemia and hepatic steatosis. In addition, a reduction in serum TC, LDL-cholesterol, and hepatic TC and TG levels was observed after supplementation (0.5\% and $0.75 \%)$.

\section{Anti-inflammatory activity}

Fermented dried Citrus unshiu peel extracts were investigated for its anti-inflammatory activities in murine macrophages and moisturizing effects in human keratinocytes (Kim et al., 2019a). Results evidenced that Citrus unshiu peels extract, rich in polyphenolic compounds, was able to suppress lipopolysaccharide (LPS)-induced NO without exerting cytotoxic effects on RAW 264.7 cells. Moreover, extracts inhibited the expression of inducible Nitric oxide synthase (iNOS), cyclooxygenase- 2 (COX-2) protein, TNF- $\alpha$, and IL-6. The inhibition of NO without compromising cell viability was also reported for Citrus reticulata peels alkaline hot water extract $\left(\mathrm{IC}_{50}\right.$ 1.04-2.74 mg/mL) (Chen et al., 2017).

Recently, the anti-inflammatory effect of Citrus sinensis peels' hydroalcoholic and methanol extracts was confirmed by Osarumwense et al. (2017). Interestingly, methanol extract was more active than hydroalcoholic extract, and a positive control drug (Indomethacin) with an inhibition of $95 \%$ on carrageenan induced rat paw edema at a concentration of $40 \mathrm{mg} / \mathrm{kg}$. Similarly, after $4 \mathrm{~h}$ of edema induction, the oral administration (300 and $500 \mathrm{mg} / \mathrm{kg}$ BW) of pomelo peels methanol extract determined an inhibition of paw edema by $34.47 \%$ and $38.68 \%$, respectively (Ibrahim et al., 2019). The same model of paw was used by Pallavi et al. (2018), establishing that intraperitoneal (i.p.) doses ( 250 and $500 \mathrm{mg} / \mathrm{kg}$ ) of pomelo peels extract inhibited paw edema (17\% and 48\%, respectively).

The mandarin dichloromethane and ethyl acetate peels' extracts against COX- 1 and COX-2 were tested (Hamdan et al., 2020). The dichloromethane extract was more active against COX-1 $\left(\mathrm{IC}_{50}=25.5 \mathrm{mg} / \mathrm{mL}\right)$ than ethyl acetate extract $\left(\mathrm{IC}_{50}=28.79 \mathrm{mg} / \mathrm{mL}\right)$; conversely against COX-2, the ethyl acetate extract had the highest activity $\left(\mathrm{IC}_{50}=3.55 \mathrm{mg} / \mathrm{mL}\right)$.

Citrus limon essential oil exhibited anti-inflammatory activity (30 or $10 \mathrm{mg} / \mathrm{kg}$ oral [p.o.]) by reducing cell migration, cytokine production, and protein extravasation induced by carrageenan (Amorim et al., 2016). Treatment (200 and $50 \mathrm{mg} / \mathrm{kg}$ ) with sweet orange dried peels essential oil evidenced a significant reduction of edema in rats (Thandiswa et al., 2020). Citrus bergamia essential oil, without furanocoumarins fraction, reduced levels of IL-1 $\beta$, IL- 6 , and TNF- $\alpha$ in the paw homogenates, nitrite/nitrate, and prostaglandin E2 (PGE2) contents in exudates, and possesses antioxidant properties (Lombardo et al., 2020).

\section{Antiproliferative activity}

Selim et al. (2019) investigated the cytotoxicity activity of Citrus reticulata peels $70 \%$ ethanolic extract against human breast carcinoma, hepatocellular liver carcinoma (HepG2), and colon carcinoma and determined the $\mathrm{IC}_{50}$ values of 34, 9.9, and $30 \mathrm{mg} / \mathrm{mL}$, respectively. Previously, the anti-cancer effects of Citrus medica (2 morphotypes), Citrus sinensis, Citrus maxima, Citrus limon, and Citrus reticolata peels' water extracts were studied (Nair et al., 2018). Among these, Citrus reticolata had significant activity against Dalton's lymphoma ascites (DLA) cell-inducing cell cycle arrest of DLA in G0/G1 phase.

\section{Antibacterial potential}

The in vivo antibacterial activity of Citrus hystrix ethanol peels extract against $S$. typhimurium was demonstrated by Zulvikar et al. (2020). In particular, the bacterial loads of this pathogen in the ileum, liver, and spleen decreased after $24 \mathrm{~h}$ of administration of the extract (16 mg daily for 3 days in a mouse). Lime peels extract was used to inhibit the colonization and growth of bacteria S. typhi in Balb/c mice. Doses of 510 and $750 \mathrm{mg} / \mathrm{kg} \mathrm{BW}$ decreased the number of S. typhi colonies; even maintenance for 20 days after the intervention showed no bacterial growth (Kasim et al., 2020). Sharma and Tyagi (2019) analyzed benzene, ethanol, and methanol peels' extracts of Citrus nobilis and Citrus sinensis against four Gram-positive and four Gram-negative bacteria and two fungal pathogens. The minimum inhibitory concentration (MIC) values in the range of $18-40 \mu \mathrm{g} / \mathrm{mL}$ were found against Bacillus cerus, S. aureus, S. epidermidis, Proteus vulgaris, S. typhimurium, P. aeruginosa, C. albicans, and Trichoderma viride for Citrus nobilis ethanolic extract, while less activity was reported for methanol and benzene extracts. The same observation was made for Citrus sinensis extracts, and, in particular, the MIC values in the range of $20-50 \mu \mathrm{g} / \mathrm{mL}$ were observed for ethanolic extract. The results were in accordance with Rehab et al. (2018) that reported antibacterial and antifungal effects of Citrus sinensis peels' hot, cold, and ethanol extracts against S. aureus, E. coli, P. aerogenes, B. cereus, and C. albicans. Interestingly, the green synthesis of zinc oxide nanoparticles using Citrus sinensis peel extract was proposed by Gao et al. (2020) in food packaging application as nanocoatings on fresh strawberries with similar antibacterial characteristic of commercial zinc oxide nanoparticles. 
The antimicrobial potential of Citrus sinensis L. and Citrus limonia Osbeck methanol, ethyl acetate, ethanol, and distilled water peels extracts was also evaluated by Saleem and Saeed (2020) against six Gram-positive (S. aureus, Aeromonas hydrophila, Enterococcus faecalis, Streptococcus pyogenes, Listeria monocytogenes, and Lactobacillus casei), six Gram-negative ( $P$. aeruginosa, K. pneumoniae, Serratia marcescens, E. coli, P. vulgaris, and S. typhi), two microscopic filamentous fungi (Aspergillus niger and Penicillium citrinum), and two yeasts ( $C$. albicans and Saccharomyces cerevisiae). Interestingly, the zone of inhibition is well comparable with amoxicillin, used as a positive control. In addition, the yellow lemon extract exhibited the highest antimicrobial activity compared to orange peels, and resulted more effectively on Gram-negative bacteria as compared to Gram-positive bacteria. Strawberries treated with Citrus limon, Citrus sinensis, and Citrus reticulata essential oils showed the highest TAC and physicochemical parameters compared to untreated fruits. This effect extends the shelflife and delays the fruit senescence (Shehata et al. 2020).

The antimicrobial effects of tangerine, grapefruit, and lemon peels' essential oils on the growth of saprophytic and pathogenic microorganisms were compared by Denkova-Kostova et al. (2020). The highest inhibitory activity was observed for grapefruit, followed by tangerine and lemon essential oil, with MIC values in the range of 60-60 ppm against E. coli, S. aureus, P. aeruginosa, and Citrus albicans. Similarly, grapefruit and lemon have respective MIC values of $0.35 \mathrm{mg} / \mathrm{mL}$ and $0.33 \mathrm{mg} / \mathrm{mL}$ against E. coli (Raspo et al., 2020). The antimicrobial effect of bitter orange essential oil against Gram-positive and Gram-negative selected bacterial strains was studied by Farahmandfar et al. (2020). MIC values of 20, 40, and $10 \mathrm{mg} / \mathrm{mL}$ were found, respectively, for E. coli, P. aeruginosa, S. aureus, and L. monocytogenes.

The addition of Citrus medica essential oil to the wines $(0.010 \%)$ determined reduction in microbial counts compared to untreated wine, and is thus proposed as bio-preservative. In particular, it the antimicrobial activity of enriched wine against the common spoilage bacteria and yeasts/molds such as Gluconobacter cerinus, Oenococcus oeni, Pediococcus pentosaceus, Dekkera bruxellensis, Candida zemplinina, Hanseniaspora uvarum, Pichia guilliermondii, or Zygosaccharomyces bailii was studied and inoculated (Mitropoulou et al., 2020).

\section{Leaves}

\section{Antioxidant effects}

The antioxidant activity of leaf methanol-water extracts of 10 varieties of citrus fruits was reported by Haraoui et al. (2020). All investigated samples exhibited radical scavenging activity with $\mathrm{IC}_{50}$ values in the same order of positive controls such as ascorbic acid and BHT. Among them, Citrus maxima and Citrus aurantium leaves showed the highest DPPH radical scavenging activity with the $\mathrm{IC}_{50}$ values of 0.51 and $0.57 \mathrm{mg} / \mathrm{mL}$, respectively (Table 5). More recently, the antioxidant activity of methanol leaves extract and ethyl acetate fraction of Citrus pseudolimon was examined (Kumar et al., 2019). The ethyl acetate fraction displayed greater DPPH radical scavenging activity than the methanol leaves extract with the $\mathrm{IC}_{50}$ values of 278.60 and $313.20 \mu \mathrm{g} / \mathrm{mL}$, respectively. The $\mathrm{IC}_{50}$ values of 476.39 and $498.26 \mu \mathrm{g} / \mathrm{mL}$ were also found in $\mathrm{H}_{2} \mathrm{O}_{2}$ scavenging assay. The methanol extract of Citrus medica leaves was also investigated for its capacity to inhibit DPPH radical (Shojaemehr et al., 2020). Similar values were observed in extracts $\left(\mathrm{IC}_{50}=0.111 \mathrm{mg} / \mathrm{mL}\right)$ and ascorbic acid $\left(\mathrm{IC}_{50}=0.109 \mathrm{mg} / \mathrm{mL}\right)$ used as control.

The citrus $\times$ clementina leaves subjected to different extractions were investigated for their antioxidant potential (Leporini et al., 2020b). The hydroalcoholic extract obtained by using ultrasound-assisted maceration had the highest antioxidant DPPH, ABTS, FRAP, and $\beta$-carotene bleaching values. Previously, methanol and aqueous leave extracts of Citrus clementina, Citrus limon, Citrus hamlin, Citrus navel, Citrus aurantifolia, Citrus aurantium, and Citrus grandi were investigated for their antioxidant activity (Khettal et al., 2017). Among aqueous extracts, Citrus limon had an important DPPH radical scavenging activity $\left(\mathrm{IC}_{50}=35.35 \mu \mathrm{g} / \mathrm{mL}\right)$, while Citrus clementina exhibited the highest ABTS radical scavenging activity $\left(\mathrm{IC}_{50}=1,174.43 \mu \mathrm{M} \mathrm{TE} / \mathrm{g}\right)$ and ferricreducing potential $\left(\mathrm{IC}_{50}=30.60 \mathrm{mg}\right.$ butyl-hydroxyanisole equivalents (BHAE)/g). Regarding methanolic extracts, Citrus clementina showed the highest antioxidant activity in all assays with the $\mathrm{IC}_{50}$ values of $41.85 \mu \mathrm{g} / \mathrm{mL}$, $378.63 \mu \mathrm{M} \mathrm{TE} / \mathrm{g} \mathrm{DM}$, and $13.85 \mathrm{mg} \mathrm{BHAE} / \mathrm{g} \mathrm{DM}$ for $\mathrm{DPPH}, \mathrm{ABTS}$ radicals scavenging activities, and ferricreducing potential, respectively. The antioxidant potential of Citrus macroptera leaf methanol extract has been recently demonstrated by Lala et al. (2020) that reported the capacity of this extract to reduce ROS, which was generated on HepG2 cell line.

Previously, Bonesi et al. (2018) investigated six citrus petitgrain essential oils for their antioxidant properties. In this study, Citrus aurantium petitgrain oil demonstrated the strongest radical scavenging activity in DPPH assay with an $\mathrm{IC}_{50}$ value of $27.2 \mu \mathrm{g} / \mathrm{mL}$, followed by citrus $\times$ clementina oil with an $\mathrm{IC}_{50}$ value of $39.0 \mu \mathrm{g} / \mathrm{mL}$, while in $\beta$-carotene bleaching test, the highest antioxidant capacity was observed with Citrus sinensis oil with the $\mathrm{IC}_{50}$ values of 176.3 and $51.3 \mu \mathrm{g} / \mathrm{mL}$ after 30 and $60 \mathrm{~min}$ of incubation, respectively. Less activity was reported for clementine essential oils by Leporini et al. (2020b). 


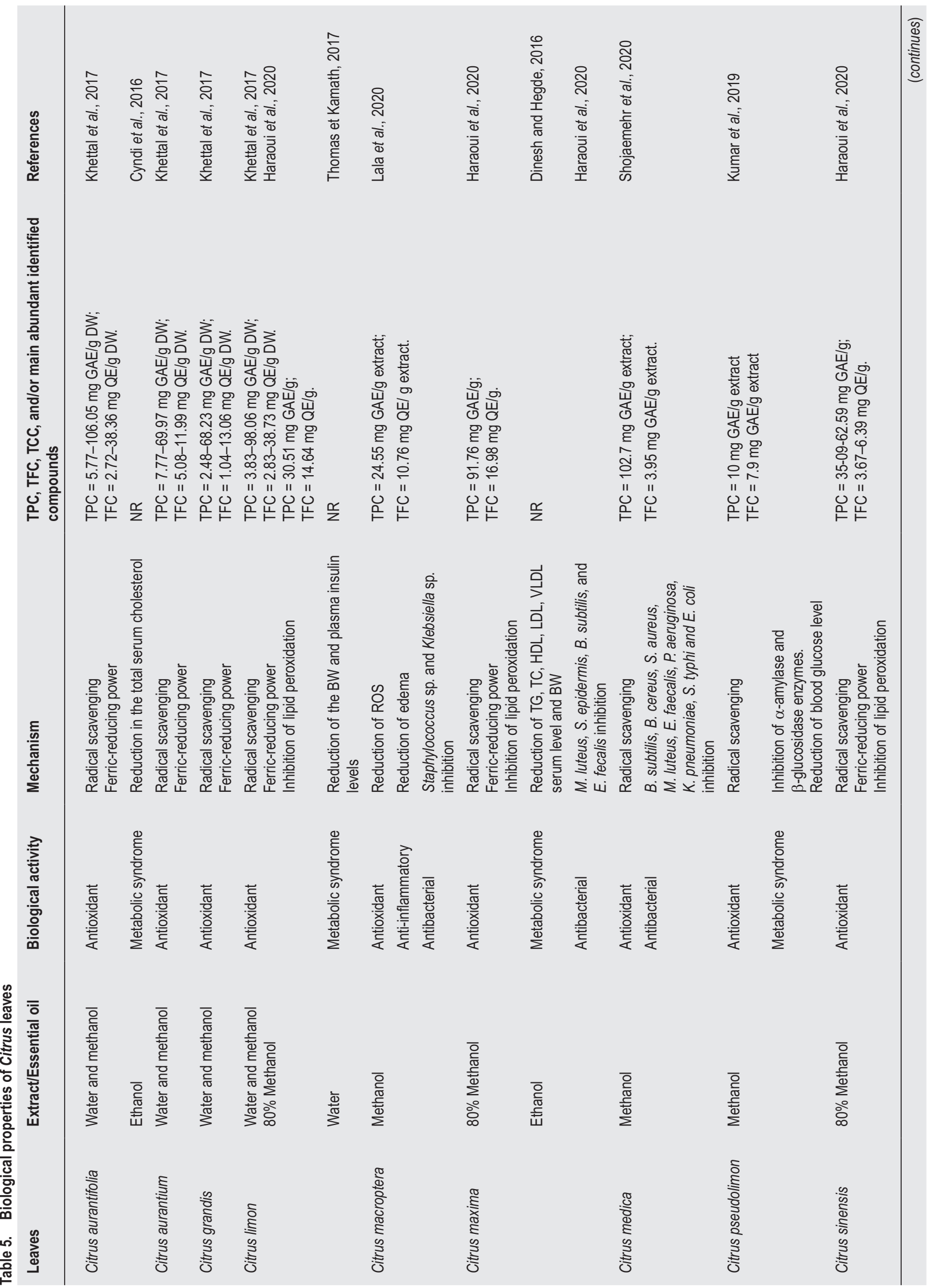




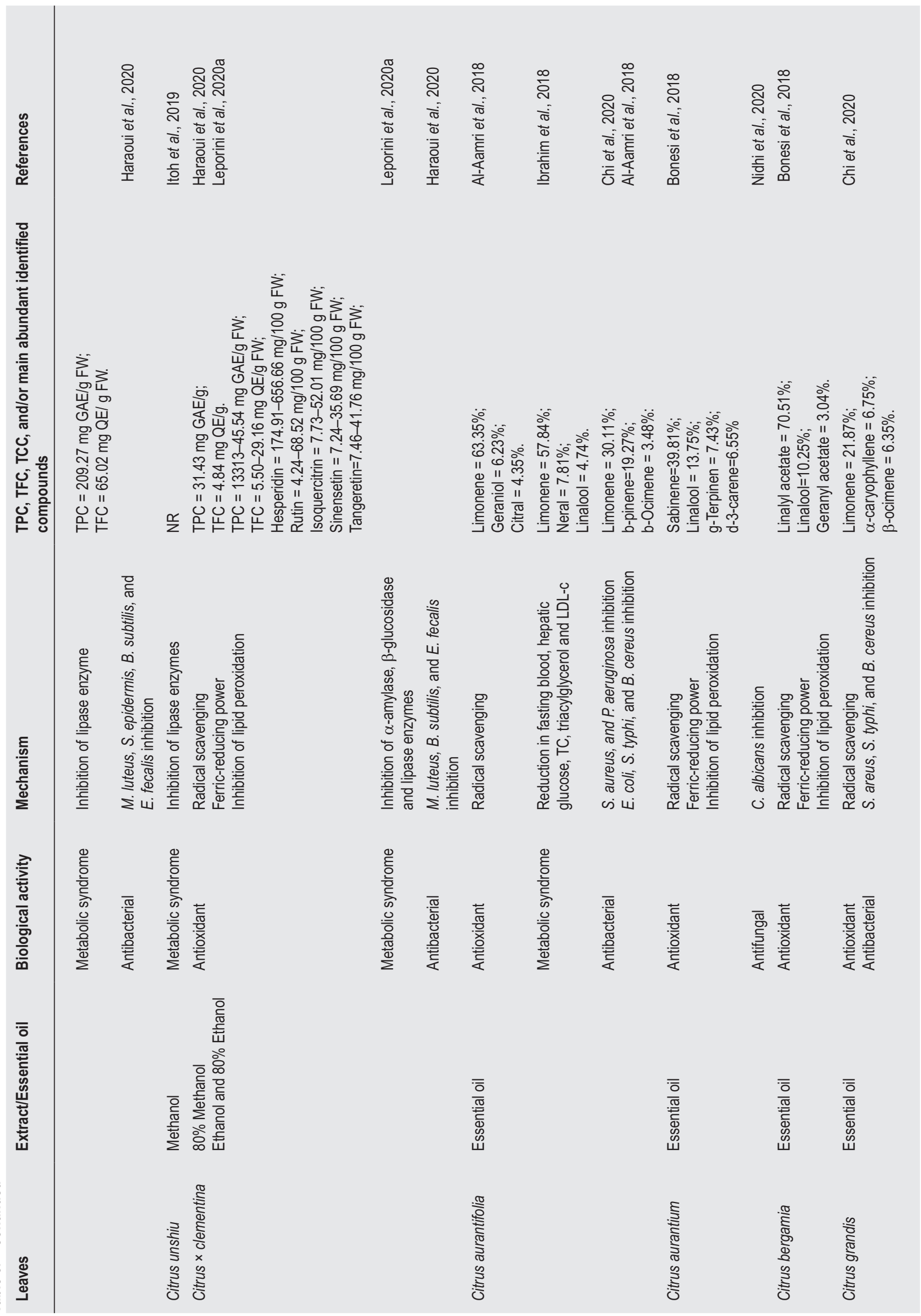




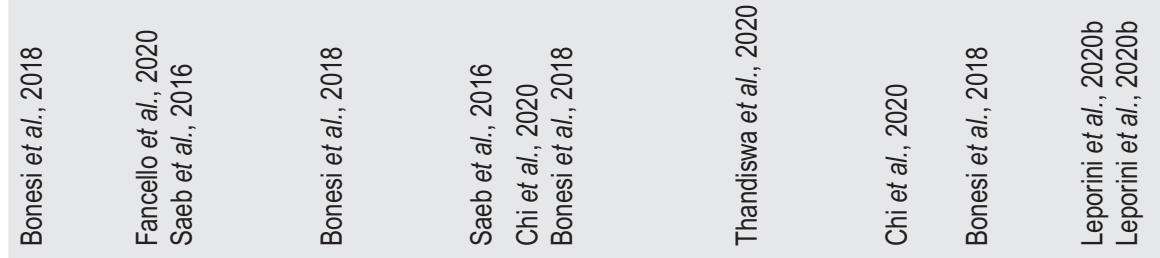
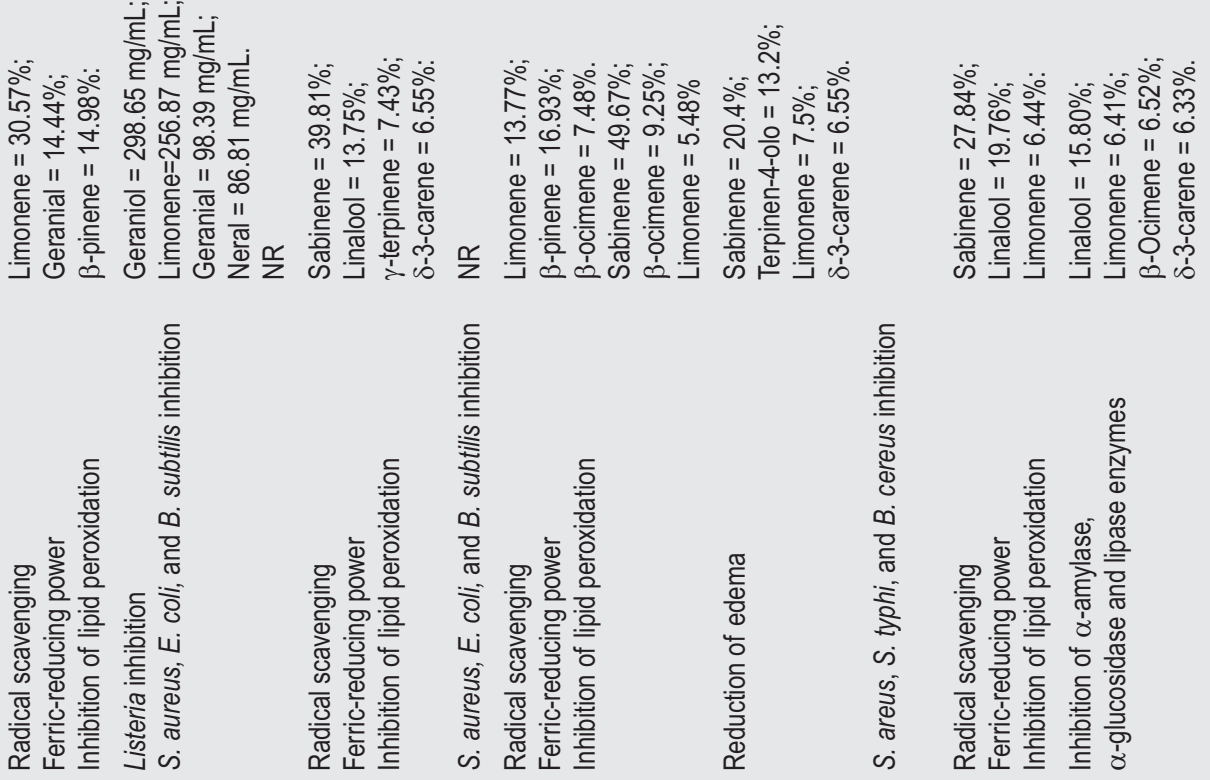


\section{Metabolic syndrome}

In recent decades, numerous in vitro and in vivo studies have demonstrated the importance of genus Citrus in the prevention of T2DM. Recently, the hypoglycemic effects of citrus $\times$ clementina leaves extract has been reported by Leporini et al. (2020b), who found the $\mathrm{IC}_{50}$ values of $64.37-247.61 \mathrm{mg} / \mathrm{mL}$ in $\alpha$-amylase enzyme and the $\mathrm{IC}_{50}$ values of $51.61-282.65 \mathrm{mg} / \mathrm{mL}$ against $\alpha$-glucosidase. In particular, hydroalcoholic extract obtained by ultrasound-assisted maceration from Corigliano Calabro leaves was found to be the most active. The addition of this extract to the juice increased its hypoglycemic $(+37 \%$ and $+25 \%$ against $\alpha$-glucosidase and $\alpha$-amylase, respectively) and hypolipidemic (+17\% against lipase) potential. The inhibitory activity of Citrus unshiu leaf methanol extract on pancreatic lipase enzyme was reported by Itoh et al. (2019) that showed an $\mathrm{IC}_{50}$ value of $44 \mu \mathrm{g} / \mathrm{mL}$.

Citrus pseudolimon methanol leave extracts and ethyl acetate fraction possessed a hypoglycemic potential (Kumar et al., 2019). The ethyl acetate fraction displayed a greater inhibition against $\alpha$-glucoside $(84.18 \%)$ in comparison to the methanol extract (82.94\%). The $\mathrm{IC}_{50}$ values of $83.66 \%$ and $78.52 \%$ for ethyl acetate and methanol extract, respectively, were found against $\alpha$-amylase. In addition, the authors indicated that oral administration of methanol leaves extract $(200 \mathrm{mg} / \mathrm{kg})$ and ethyl acetate fraction $(100 \mathrm{mg} / \mathrm{kg})$ for 21 days decreased the fasting blood glucose level in diabetic rats. Aqueous extract of Citrus limon leaves was tested against STZ-induced diabetic rats. This extract, orally administered at doses of $50 \mathrm{mg} / \mathrm{kg} \mathrm{BW}$ and $100 \mathrm{mg} / \mathrm{kg}$ BW for 28 days, decreased BW and plasma insulin levels and increased blood glucose levels (Thomas and Kamath, 2017). The hypocholesterolemic effects of Citrus aurantifolia was reported by Cyndi et al. (2016). Indeed, the ethanol extract of leaves determined reduction in TC serum in mice, with the most significant reduction at a dosage of $3.5 \mathrm{~g} / \mathrm{kg}$ BW. Similarly, the oral administration of Citrus maxima leaves extract (200 and $400 \mathrm{mg} / \mathrm{kg} \mathrm{BW}$ ) in obese rats determined reduction in TG, TC, HDL, LDL, and very low-density lipoprotein (VLDL) serum levels and BW (Dinesh and Hegde, 2016).

\section{Antibacterial effect}

More recently, Haraoui et al. (2020) investigated the antibacterial activity of leaves methanol water extracts obtained from Citrus aurantium, Citrus maxima, Citrus lemon, Citrus Clementine, and Citrus sinensis cv. Sanguinelli, Thomson, Washington, Portuguese, Double Fine, and Jafa. M. luteus resulted in the most sensitive Gram-positive bacteria to the action of Citrus aurantium and Citrus sinensis cv. Jaffa leave extracts with an inhibition area of $20.00 \mathrm{~mm}$ and $16.00 \mathrm{~mm}$, respectively. For Gram-negative bacteria, the best results were observed for the Citrus lemon extract with an inhibition area of $15.66 \mathrm{~mm}$ (P. aeruginosa) and $15.33 \mathrm{~mm}$ (E. coli).

The antibacterial effects of different extracts obtained from Citrus medica leaves were tested. Interestingly, the inhibitory activity of methanol extract on B. cereus, $E$. coli, and E. aerogenes was more potent than the gentamicin used as a positive control (Shojaemehr et al., 2020).

Citrus aurantium leaves essential oil demonstrated strong antifungal activity against two strains of Citrus albicans with MIC values of $0.15-0.31 \%$ (v/v) (Nidhi et al., 2020). Interestingly, Citrus limon var pompia leaves essential oil showed specific anti-listeria activity on ricotta salata cheese (Fancello et al., 2020). Recently, De Oliveira Filho et al., (2020) proposed a chitosan films enriched with Citrus limonia leaves essential oil as an active packaging material for food preservation for its capacity to: (a) reduce the moisture content and water vapor permeability; (b) decrease the visible light transmission rate values; (c) change the color of bioactive films significantly, remaining darker and yellowish; and (d) inhibit S. aureus. Similarly, the addition of lemon essential oil to chitosan coatings enhanced fermentative process during storage, with modification of strawberry fruit aroma composition notably appreciated (Perdones et al., 2015).

\section{Bioactive compounds}

Polyphenolic compounds are a wide group of metabolites that originate from the secondary metabolism of plants. These are considered as potent antioxidants for their capacity to increase catalase activity, trap reactive oxygen species, and to act as a metal chelator. Additionally, they determined the inhibition of chain lipid peroxidation by trapping peroxyl radical and quickly reacted with peroxy nitrite (Pisoschi and Pop, 2015). Flavonoids and phenolic acid (Figure 1) are dominant bioactive compounds found in citrus. In particular, peels are rich in flavone aglycons and polymethoxy flavones, rarely found in other plants. Polyphenols are present in both edible and nonedible parts of the fruits (Singh et al., 2020). In addition, citrus fruit is a good source of carotenoids (Figure 2) compounds recognized for their beneficial effects on human health (Ikoma et al., 2016).

Citrus by-products represented a rich source of essential oils that possessed a wide range of antioxidant, antimicrobial, and antidiabetic properties, and thus used in pharmaceutical and food industries (Bora et al., 2020). 


\section{Flavonoids}

Flavonoids are secondary metabolites in plants, with a multitude of functions: They regulate the development of plants, their pigmentation, and protect them from UV-light. Furthermore, they act as defense and signaling between plants and microorganisms (Mathesius, 2018).

\section{Hesperidin}

Hesperidin is one of the main flavanone glycosides know in citrus fruits. Great attention has been focused on hesperidin and its aglycone form, hesperetin, which plays an important role in the prevention of diseases associated with oxidative stress such as obesity, diabetes, inflammation, and cancer (Barreca et al., 2017). Its antioxidant mechanism was correlated to direct ROS scavenging, transition metal ion chelation, and its ability to increase cellular glutathione content. De Souza et al. (2016) compared the antioxidant activity of hesperidin, hesperetin, and G-hesperidin in vitro and in vivo, administrating each of these for 30 days at $1 \mathrm{mmol} / \mathrm{kg}$ body mass to Wistar male rats. The aglycone form has the greatest inhibitory activity of xanthine oxidase by increasing superoxide dismutase (SOD) activity in the liver of animals. Recently, the antioxidant activity of hesperidin, and its ability to inhibit pancreatic lipase enzyme, was studied (Huang et al., 2020). Results demonstrated that hydrogen bonds and van der Waals forces played major roles in the interaction of hesperidin and lipase.

The metabolic effects of hesperidin were also demonstrated by Sahnoun et al. (2017) and Zeng et al. (2018), who reported its ability to inhibit $\alpha$-amylase, $\alpha$-glucosidase, and lipase enzyme with the $\mathrm{IC}_{50}$ values of 111 and $1 \mu \mathrm{M}$, and $688.25 \mu \mathrm{g} / \mathrm{mL}$, respectively. In a randomized double-blind controlled clinical trial design, 23 subjects with T2DM consumed $500 \mathrm{mg} /$ day hesperidin supplement for 8 weeks. Hesperidin supplementation led to significant decrease in fasting blood glucose and glycosylated hemoglobin (HbA1c). A significant increase in serum insulin and decrease in TG were also observed in the hesperidin-treated group (Eghtesadi et al., 2016). Similarly, the supplementation with hesperidin $(500 \mathrm{mg} /$ day for 8 weeks) in T2DM patients resulted in reduction of fasting blood glucose, TC, and HbA1c, and at the same time a significant increase in serum insulin (Mohammadi et al., 2016). A dose of $100 \mathrm{mg}$ or $500 \mathrm{mg}$ of hesperidin for 6 weeks in subjects with hypercholesterolemia decreased serum TG and LDL levels (Li and Schluesener, 2017). In addition, intra-gastric hesperidin attenuates the increased level of plasma cholesterol, LDL-cholesterol VLDL-cholesterol, TG, free fatty acids, and phospholipids, and decreased levels of high-density lipoprotein-cholesterol (HDL-c) (Homayouni et al., 2017).
In an in vivo study, hesperidin and naringin increased the production and release of insulin from the islet cells and decreased intestinal glucose absorption (Mahmoud et al., 2015). In addition, hesperidin and hesperetin inhibited two gluconeogenesis enzymes, alanine aminotransferase and aspartate aminotransferase, indicating their effectiveness in treating diabetes mellitus (Zareei et al., 2017).

The therapeutic potential of hesperidin has been confirmed recently (Rehman et al., 2020b). This flavanone improved leptin and insulin resistance, IL- 6 and TNF- $\alpha$ more significantly compared to the reference drug Orlistat used in high fat diet (HFD)-induced obese rats. In addition, the treatment with 500-mg hesperidin significantly reduced the plasma levels of C-reactive protein and serum amyloid A in individuals with MS (Homayouni et al., 2017). Moreover, hesperidin reduced symptoms of MS and improved cardiac function in HFDinduced MS in rats (Prasatthong et al., 2021). Indeed, treatment with hesperidin (15 or $30 \mathrm{mg} / \mathrm{kg}$ ) ameliorated cardiac dysfunction and hypertrophy in rats, restored the insulin signaling pathway, and IRS/Akt/GLUT4 protein expression.

The consummation $(500 \mathrm{~mL})$ of orange juice enriched with hesperidin had positive effects on blood and pulse pressures in mildly hypertensive individuals (Valls et al., 2021). The results are in accordance with a recent study in which high blood pressure was attenuated by hesperidin $(50 \mathrm{mg} / \mathrm{kg} \mathrm{BW})$. Regulation in the expressions of TNF- $\alpha$, COX-2, and PGE2 with improvement of oxidative stress by increasing glutathione reductase and decreasing malondialdehyde (MAD) was also observed (Khidr et al., 2020).

Previously, the cardioprotective effect of hesperidin was investigated by Haidari et al. (2015). Administration of $600 \mathrm{mg} /$ day of hesperidin decreases levels of adiponectin and HDL-cholesterol and increases E-selectin in patients with myocardial infarction.

The neuroprotective activity of hesperidin was evaluated by Thenmozhi et al. (2015). In this study, administration of $100 \mathrm{mg} / \mathrm{kg}$ of hesperidin along with aluminum chloride $\left(\mathrm{AlCl}_{3}\right)$ injection for 60 days significantly reduced the concentration of ROS in hippocampus and cortex, the AchE activity, the protein expressions of amyloid precursor protein, the levels of both $\mathrm{Ab}_{1-42}$ and $\mathrm{b}$ and $\mathrm{g}$ secretases. Recently, Li and Schluesener (2017) demonstrated that administration of $100 \mathrm{mg} / \mathrm{kg}$ of hesperidin for 10 days significantly attenuated $\alpha$-amyloid deposition and microglial activation in brain of transgenic mice.

The combination of diosmin and hesperidin exerted analgesic and/or anti-inflammatory effects (Patent No. 
<smiles>[R]c1cc(C2CC(=O)c3c([R])c([R])c([R])c([R])c3O2)cc([R])c1[R]</smiles>

\begin{tabular}{cccccccc}
\hline NAME & $\mathrm{R}_{1}$ & $\mathrm{R}_{2}$ & $\mathrm{R}_{3}$ & $\mathrm{R}_{4}$ & $\mathrm{R}_{5}$ & $\mathrm{R}_{6}$ & $\mathrm{R}_{7}$ \\
\hline Naringenin & $\mathrm{OH}$ & $\mathrm{H}$ & $\mathrm{OH}$ & $\mathrm{H}$ & $\mathrm{H}$ & $\mathrm{OH}$ & $\mathrm{H}$ \\
Hesperetin & $\mathrm{OH}$ & $\mathrm{H}$ & $\mathrm{OH}$ & $\mathrm{H}$ & $\mathrm{OH}$ & $\mathrm{OCH}_{3}$ & $\mathrm{H}$ \\
Narirutin & $\mathrm{OH}$ & $\mathrm{H}$ & $\mathrm{O}-\mathrm{Rut}$ & $\mathrm{H}$ & $\mathrm{H}$ & $\mathrm{OH}$ & $\mathrm{H}$ \\
Naringenin & $\mathrm{OH}$ & $\mathrm{H}$ & $\mathrm{O}-\mathrm{Neo}$ & $\mathrm{H}$ & $\mathrm{H}$ & $\mathrm{OH}$ & $\mathrm{H}$ \\
Poncirin & $\mathrm{OH}$ & $\mathrm{H}$ & $\mathrm{O}-\mathrm{Neo}$ & $\mathrm{H}$ & $\mathrm{H}$ & $\mathrm{OCH}_{3}$ & $\mathrm{H}$ \\
Eriocitrin & $\mathrm{OH}$ & $\mathrm{H}$ & $\mathrm{O}-\mathrm{Rut}$ & $\mathrm{H}$ & $\mathrm{OH}$ & $\mathrm{OH}$ & $\mathrm{H}$ \\
Neoeriocitrin & $\mathrm{OH}$ & $\mathrm{H}$ & $\mathrm{O}-\mathrm{Neo}$ & $\mathrm{H}$ & $\mathrm{OH}$ & $\mathrm{OH}^{2}$ & $\mathrm{H}$ \\
Hesperidin & $\mathrm{OH}$ & $\mathrm{H}$ & O-Rut & $\mathrm{H}$ & $\mathrm{OH}$ & $\mathrm{OCH}_{3}$ & $\mathrm{H}$ \\
Neohesperidin & $\mathrm{OH}$ & $\mathrm{H}$ & O-Neo & $\mathrm{H}$ & $\mathrm{OH}$ & $\mathrm{OCH}_{3}$ & $\mathrm{H}$ \\
Didymin & $\mathrm{OH}$ & $\mathrm{H}$ & O-Rut & $\mathrm{H}$ & $\mathrm{H}$ & $\mathrm{OCH}_{3}$ & $\mathrm{H}$ \\
\hline
\end{tabular}

(a) Structure of flavones<smiles>[R]c1cc(-c2cc(=O)c3c([R])c([R])c([R])c([R])c3o2)cc([R])c1[R]</smiles>

\begin{tabular}{cccccccc}
\hline NAME & $\mathrm{R}_{1}$ & $\mathrm{R}_{2}$ & $\mathrm{R}_{3}$ & $\mathrm{R}_{5}$ & $\mathrm{R}_{5}$ & $\mathrm{R}_{6}$ & $\mathrm{R}_{7}$ \\
\hline Apigenin & $\mathrm{OH}$ & $\mathrm{H}$ & $\mathrm{OH}$ & $\mathrm{H}$ & $\mathrm{H}$ & $\mathrm{OH}$ & $\mathrm{H}$ \\
Luteolin & $\mathrm{OH}$ & $\mathrm{H}$ & $\mathrm{OH}$ & $\mathrm{H}$ & $\mathrm{OH}$ & $\mathrm{OH}$ & $\mathrm{H}$ \\
Sinensetin & $\mathrm{OCH}_{3}$ & $\mathrm{OCH}_{3}$ & $\mathrm{OCH}_{3}$ & $\mathrm{H}$ & $\mathrm{OCH}_{3}$ & $\mathrm{OCH}_{3}$ & $\mathrm{H}$ \\
Tangeretin & $\mathrm{OCH}_{3}$ & $\mathrm{OCH}_{3}$ & $\mathrm{OCH}_{3}$ & $\mathrm{OCH}_{3}$ & $\mathrm{H}$ & $\mathrm{OCH}_{3}$ & $\mathrm{H}$ \\
Nobiletin & $\mathrm{OCH}_{3}$ & $\mathrm{OCH}_{3}$ & $\mathrm{OCH}_{3}$ & $\mathrm{OCH}_{3}$ & $\mathrm{OCH}_{3}$ & $\mathrm{OCH}_{3}$ & $\mathrm{H}$ \\
\hline
\end{tabular}

(b) Structure of flavones<smiles>[R]c1cc(-c2oc3cc(O)cc(O)c3c(=O)c2O)ccc1O</smiles>

\begin{tabular}{cc}
\hline NAME & $\mathrm{R}_{1}$ \\
\hline Quercetin & $\mathrm{OH}$ \\
Kaempferol & $\mathrm{OH}$ \\
Rutin & $\mathrm{OCH}_{3}$ \\
\hline
\end{tabular}

(c) Structure of flavonols<smiles>O=C(/C=C/c1ccc(O)c(O)c1)O[C@@H]1C[C@@](O)(C(=O)O)C[C@H](O)[C@H]1O</smiles>

(A)<smiles>O=C(O)C=Cc1ccc(O)c(O)c1</smiles>

(B)<smiles>O=C(O)c1cc(O)c(O)c(O)c1</smiles>

(C)

(d) Chlorogenic (A), gallic (B) and caffeic acid (C)

Figure 1. The main phenolic constituents of Citrus species.

WO2015019334) as reported by López Muñozmaría et al. (2015). This application was used for the treatment of different kinds of pain: moderate to severe pain, chronic pain, and/or neuropathic pain. No occurrence of adverse effects was observed.
Supplementation of a mixture of Imperata cylindrical, Citrus unshiu markovich-hesperidin, and Evodia officinalis Dode-Evodiamine for 12 weeks significantly reduced the $\mathrm{BW}$, body fat mass, and waist circumference in overweight subjects (Cho et al., 2017). Recently, it was 


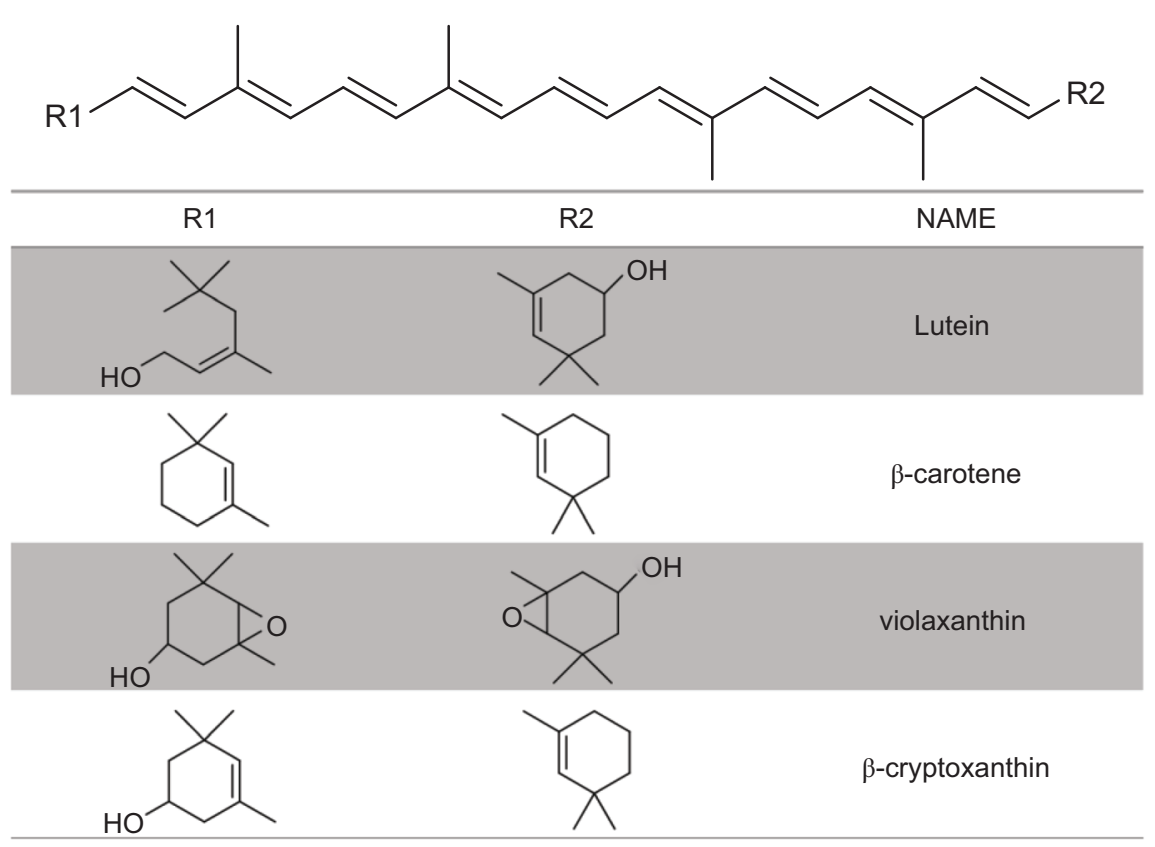

Figure 2. The most abundant Citrus carotenoids.

reported that hesperidin ameliorates hepatic dysfunction and dyslipidemia in male Wistar rats exposed to cadmium chloride (Aja et al., 2020).

\section{Hesperetin}

Recently, hesperetin showed cellular antioxidant activity with a value of $23.57 \mu \mathrm{mol}$ of QE/100 $\mu \mathrm{mol}$ (Huang et al., 2020). Both hesperidin and hesperetin were able to reduce oxidative stress directly by scavenging intracellular ROS and increase natural antioxidant defense system with particular reference to glutathione (Dhanya and Jayamurthy, 2020). In addition, these flavonoids inhibited the non-enzymatic glycation of proteins involved in the formation of advanced glycation end-products which have an important role in developing diabetes. Previously, Jayaraman et al. (2018) investigated the anti-hyperglycemic, antioxidant, and anti-hyperlipidemic effects of hesperetin against STZ-induced experimental rats. Supplementation with $40 \mathrm{mg} / \mathrm{kg}$ of hesperetin for 45 days determined a significant decline in plasma glucose level and a marked improvement in insulin and glycogen secretions.

Hesperetin is also known to induce apoptosis in cancer cells primarily through activation of caspase- 9 (Farooqi et al., 2015). This compound revealed significant cytotoxicity for HeLa cell line, and its anticancer ability was revalidated by in silico molecular docking study, which exhibited strong interaction with E6 protein of HPV16 cervical carcinoma with significant binding energy (Prakash et al., 2020). The capacity of hesperetin to attenuate testicular alteration in Wistar rats was also reported through inhibition of inflammation, oxidative stress, and apoptosis (Samie et al., 2018).

Interestingly, Li et al. (2018; Patent No. CN108815154A) investigated the ability of hesperetin to inhibit chloride channel and propose its use for the treatment of diarrhea, heart disease, pulmonary disease, stomach, brain, and mental diseases, rhinitis, ontological disease, and eye disease drug development.

Hesperetin administered orally $(50 \mathrm{mg} / \mathrm{kg} / \mathrm{day}$ for 46 days) reduced ROS, DNA fragmentation, serum glucose, MDA levels, and caspase 3 activity. In addition, this compound potentiated testicular antioxidant system with consequent increase in glutathione levels, ferric-reducing antioxidant power, catalase (CAT), SOD, and glutathione peroxidase (GPx) activity in diabetic rats (Samie et al., 2018). Shagirtha et al. (2017) has recently demonstrated the neuroprotective properties of hesperetin. The oral administration of this flavanone $(40 \mathrm{mg} / \mathrm{kg}$ BW for 21 days) protected the brain of Wistar rats by increasing the levels of enzymatic antioxidants such as CAT, SOD, GPx, and glutathione-s-transferase (GSTs). In addition, hesperetin reduced oxidative stress, neuroinflammation, and motor dysfunction as well as amyloidogenesis and cognitive dysfunction in mice with positive effect against Parkinson's and Alzheimer's diseases (Khan et al., 2020).

\section{Neohesperidin}

The in vivo hypoglycemic and hypolipidemic effects of neohesperidin on KK-A(y) mice were studied (Jia et al., 2015). Treatment with neohesperidin significantly 
decreased serum glucose, fasting glucose, glycosylated serum protein, and insulin resistance. Moreover, this bioactive compound significantly decreased TC, serum TG, leptin level, and inhibited lipid accumulation. Lv et al. (2015) also noted that naringin and neohesperidin mainly inhibited amylose digestion. In addition, the neohesperidin administration $(50 \mathrm{mg} / \mathrm{kg} /$ day $)$ attenuates weight gain, low-grade inflammation, and insulin resistance in mice, as well as restored gut barrier damage and metabolic endotoxemia (Lu et al., 2020).

A novel pharmaceutical use of neohesperidin in the preparation of drug for treating bronchial asthma or diseases caused by Th1/Th 2 cell immune imbalance was disclosed (Shi and Yang, 2018; Patent No. CN108478586).

The efficacy of citrus flavonoids on MS resulted in the commercialization of Bergavit ${ }^{\circ}$, a standardized extract containing $150 \mathrm{mg}$ of main active flavonoids of bergamot juice (16\% of neoeriocitrin, $47 \%$ of neohesperidin, and $37 \%$ of naringin). This supplement was administrated at a fixed daily dose for 6 months in patients with moderate hypercholesterolemia. Results revealed reduction in TG, TC, and LDL-cholesterol (Toth et al., 2016).

It has been demonstrated recently that the neohesperidin inhibited Angiotensin II-induced myocardial contractile dysfunction, and reduced hypertension, myocardial hypertrophy, fibrosis, SOD production, and inflammation (Zhang et al., 2020).

\section{Naringenin}

Naringin, as reported by Sahnoun et al. (2017), showed an excellent inhibition for $\alpha$-amylase and $\alpha$-glucosidase enzyme, with $\mathrm{IC}_{50}$ values of $8.0 \mu \mathrm{M}$ and $0.55 \mu \mathrm{M}$, respectively. Lim et al. (2018) studied the protective effects and molecular mechanisms of naringin in diabetic mice. The results showed that this flavanone ameliorated hyperglycemia and protected STZ-induced $\beta$-cell death by inhibiting both intrinsic and extrinsic apoptotic pathways. These protective effects have been related to the ability of naringin to reduce ROS and pro-inflammatory cytokines accumulation. It was suggested recently that antioxidant and anti-inflammatory properties of naringenin could confer hepatoprotective effects after oral treatment with $60 \mathrm{mg} / \mathrm{kg} \mathrm{BW}$ (Kometsi et al., 2020).

In a clinical study, administration of naringin $(400 \mathrm{mg} /$ capsule/day) for 8 weeks in hypercholesterolemic individuals resulted in reduced concentration of plasma TC and LDL-cholesterol. Naringin exerted its effect by inhibiting gluconeogenesis and upregulation of AMPK, hence metformin-like effects. In addition, it increased glucose uptake in skeletal muscles, ameliorated proinflammatory reactions, and prevented metabolic dysregulation and atherosclerosis (Nyane et al., 2017).
Moreover, naringenin decreased blood glucose, serum lipid, and ameliorated glucose tolerance through downregulating oxidative stress and inflammation in STZinduced rats (Jia et al., 2015).

Liang et al. (2015; Patent No. CN104940932A) reported the protective effects of naringenin and naringin during radiotherapy. Additionally, the use of naringenin and its derivative in preventing Alzheimer's disease and other cognitive disorders was reported (Liao, 2018; Patent No. CN108785301A).

The administration of naringenin $(50 \mathrm{mg} / \mathrm{kg} / \mathrm{day})$ increased the serum level of insulin and consequently glucose uptake, improved lipid profile, TNF- $\alpha$, IL-6, normalized level of NO, and increased SOD level (Rehman et al., 2020c). These effects were confirmed by Wu et al. (2016); they showed how this compound inhibited the expression of cytokine signaling, iNOS, COX-2, and release of NO and pro-inflammatory cytokines in microglial cells. A direct effect of this flavanone determined downregulation of genes involved in de novo lipogenesis, lipolysis, and triglyceride synthesis/storage. Moreover, narirutin and didymin are able to inhibit lipase enzyme with the $\mathrm{IC}_{50}$ values of 58.98 and $67.30 \mu \mathrm{g} / \mathrm{mL}$, respectively (Zeng et al., 2018).

\section{Didymin}

Didymin acted as an anticancer agent by inhibiting phthalate-mediated invasion, migration, and proliferation of breast cancer cells (Hsu et al., 2016), and as a scavenger of free radicals (Lin et al., 2016). More recently, Ali et al. (2019) demonstrated that didymin was also able to inhibit $\alpha$-glucosidase and $\alpha$-amylase enzymes and increase glucose uptake. In addition, didymin reduced the expression of two key enzymes involved in the gluconeogenesis such as glucose 6-phosphatase and phosphoenolpyruvate carboxy-kinase with a consequent decrease of glucose production. Recently, it was found that didymin prevented hyperglycemia-induced ROS, production of lipid peroxidation product MAD, hyperglycemiainduced monocyte-endothelial cell adhesion, and nuclear factor kappa-light-chain-enhancer of activated B cells (NF-kB) activation. In addition, this compound inhibited the release of various inflammatory cytokines and chemokines (Kirtikar et al., 2018).

\section{Eriocitrin}

Eriocitrin is known as a strong antioxidant agent (Smeriglio et al., 2019). It has been shown that a major role is played by its two hydroxy groups that are bound to the B ring in ortho position with respect to each other (Diab et al., 2015). This flavanone $(200 \mathrm{mg} / \mathrm{kg})$ showed protective effects against inflammation and oxidative stress in C57BL/6J mice, and may therefore prevent metabolic alterations associated with the development of cardiovascular diseases (Ferreira et al., 2016). 
More recently, Kwon and Choi (2020) proposed a possible eriocitrin mechanism of action. In this study, dietary supplementation with eriocitrin $(0.005 \%)$ in $\mathrm{C} 57 \mathrm{BL} / 6 \mathrm{~N}$ mice for 16 weeks improved adiposity by increasing adipocyte fatty acid oxidation, energy expenditure, mRNA expression of thermogenesis-related genes in brown adipose tissue and skeletal muscle, and decreasing the expression of lipogenesis-related genes in white adipose tissue. The supplementation with eriocitrin also decreased hepatic lipogenesis and prevented hyperlipidemia whereas increased hepatic fatty acid (FA) oxidation and fecal lipid excretion. Moreover, eriocitrin supplementation improved insulin resistance, glucose tolerance, and decreased hepatic gluconeogenesis and pro-inflammatory responses. Previously, Liu et al. (2019a; Patent No. CN109806272A) proposed eriocitrin as potential $\alpha$-glucosidase inhibitor.

\section{Nobiletin}

Nobiletin is one of the most abundant polymethoxylated flavones. This compound was investigated for its capacity to improve and prevent obesity and metabolic diseases. Recently, the application of nobiletin in preparation treatment of gastric accommodation disorder remedies was reported (Li, 2019; Patent No. CN108619130B). This compound selectively relaxes stomach smooth muscles, promotes the recovery of physiological gastrointestinal motility, and calms stomach upset. As a new therapeutic agent, it has provided and presented great market prospects and economic value.

Sahnoun et al. (2017) reported the carbohydrate hydrolyzing enzymes inhibitory activity of nobiletin with the $\mathrm{IC}_{50}$ values of $42.0 \mu \mathrm{M}$ and $50.0 \mu \mathrm{M}$ against $\alpha$-amylase and $\alpha$-glucosidase, respectively. This flavone was also able to inhibit lipase with an $\mathrm{IC}_{50}$ value of $26.28 \mathrm{mg} / \mathrm{mL}$ (Zeng et al., 2018), with $\mathrm{IC}_{50}$ value being better than that those reported for the positive control. In $\mathrm{db} / \mathrm{db}$ diabetic mice, oral administration of nobiletin $(200 \mathrm{mg} / \mathrm{kg} \mathrm{BW}$ for 10 weeks) significantly attenuated BW gain, decreased fasting glucose levels, improved glucose tolerance and insulin sensitivity, and diminished serum TG levels (He et al., 2016). Moreover, nobiletin was able to reduce the protein peroxisomal acyl-coenzyme A oxidase 1 , carnitine palmitoyltransferase- 1 , and ameliorated fatty acids $\beta$-oxidation via AMPK (Lone et al., 2018). In addition, treatment with this compound at $10-100 \mathrm{mg} / \mathrm{kg} \mathrm{BW}$ for 8 weeks in obese mice accelerated lipid catabolism in adipose tissues.

Recently, it was found that nobiletin improved cognitive deficits and the pathological features of Alzheimer's disease, such as $\mathrm{A} \beta$ pathology, hyperphosphorylation of tau, and oxidative stress (Nakajima and Ohizumi, 2019). In addition, nobiletin ameliorated motor and cognitive deficits in Parkinson's disease models. Qi et al. (2019) also demonstrated that oral administration of nobiletin
(100 mg/kg/day for 6 weeks) ameliorated LPS-triggered memory deficit regarding synaptic dysfunctions and neuronal loss, and inhibited the microglial activation and pro-inflammatory cytokine secretion (IL- $1 \beta$, COX-2, TNF- $\alpha$, and iNOS). In addition, in BV-2 microglia cells, the action of this flavone decreased pro-inflammatory cytokines secretion, and channeled modulation of mitogen-activated protein kinase (MAPKs), phosphatidylinositol 3-kinase/phosphorylated protein kinase B (PI3K/Akt), and NF- $\mathrm{kB}$ signaling pathways. Interestingly, nobiletin promotes antioxidant and anti-inflammatory responses and elicits protection against ischemic stroke in vivo with increase in the expression of SOD and glutathione (GSH) which are responsible of antioxidant endogenous defense systems. Moreover, a reduction in the levels of NF- $\mathrm{kB}$ and MDA was also observed (Zhang et al., 2016).

Wen-Zhe et al. (2015; Patent No. US9808477B2) detected a pharmaceutical composition for multidrug-resistant cancer treatment comprising citrus methoxyflavone (nobiletin) and chemotherapeutic drug. In addition, Chen and Wang (2015; Patent No. CN105030559A) proposed application of nobiletin in preparation of health products or medicines for prevention and/or treatment of oral cancer. The experiments showed that these compounds possessed an obvious effect on inhibiting proliferation of human oral epidermoid carcinoma cells through the anti-proliferation effects of hesperetin, naringenin, and nobiletin on human oral epidermoid carcinoma cells.

\section{Tangeretin}

Both nobiletin and tangeretin ameliorated ROS production and lipid peroxidation in mutant Saccharomyces cerevisiae deficient in glutathione synthase, SOD, or CAT (Wang et al., 2018). Similarly, a significant decrease in ROS content, with increase in the activities of SOD, CAT, and GPx through inhibition of NF-kB pathway in rats' insulinoma cell line (INS-1) pre-treated with tangeretin $(0,10$, or $20 \mu \mathrm{M}$ ) for $12 \mathrm{~h}$ was also observed (Liu et al., 2019b).

Recent report has elucidated the anti-obesity capacity of tangeretin via inhibition of pancreatic lipase. This compound inhibited the enzyme with an $\mathrm{IC}_{50}$ value of 57.31 $\mathrm{mg} / \mathrm{mL}$ (Zeng et al., 2018). Moreover, tangeretin ameliorated insulin resistance and increased glucose uptake by attenuating obesity-induced inflammation in adipose tissue through reduction of $\mathrm{NO}$ production, the expression of IL-6, IL-1 $\beta$, TNF- $\alpha$, iNOS, and COX-2 in 3T3-L1 adipocytes and macrophage cell line (Shin et al., 2017). Sahnoun et al. (2017) evaluated the inhibitory activities of tangeretin on carbohydrate metabolism key enzymes. This pentamethoxy flavone showed the $\mathrm{IC}_{50}$ values of $141.0 \mu \mathrm{M}$ and $14.8 \mu \mathrm{M}$ against $\alpha$-amylase and $\alpha$-glucosidase, respectively.

Recently, the neuroprotective effect of tangeretin against cerebral ischemia-reperfusion injury was demonstrated 
(Yang et al., 2020). This compound downregulated the inflammatory and pro-inflammatory cytokines and oxidative stress parameters in the serum and brain tissues of rats with suppression of IL-1 $\beta$, TNF- $\alpha$, and IL-6. Lee et al. (2018; Patent No. KR102015221B1) proposed the application of tangeretin for the prevention and treatment of post-traumatic stress disorder. This compound showed an excellent anti-anxiety effect, and was consequently included in the pharmaceutical composition of foods as an active ingredient. Moreover, tangeretin was an active ingredient for alleviating, preventing, or treating renal fibrosis or cirrhosis of kidney glomerulus or albuminuria (Young-Hee and Min-Kyung, 2018; Patent No. KR101949471B1).

\section{Sinensetin}

The effects of sinensetin on lipid metabolism in mature 3T3-L1 adipocytes without causing cytotoxicity were reported by Kang et al. (2015). This compound showed anti-adipogenic property by downregulation of sterol regulatory element-binding protein 1c, and lipolytic property with increase of lipase enzyme. Moreover, sinensetin inhibited insulin-stimulated glucose uptake by decreasing the phosphorylation of insulin receptor substrate, and increased the phosphorylation of AMPK and acetyl-CoA carboxylase. It also upregulated mRNA expression of carnitine palmitoyltransferase-1a, suggesting that sinensetin enhances fatty acid $\beta$-oxidation through AMPK pathway. In addition, it was found that sinensetin quenched the fluorescence of $\alpha$-glucosidase, and inhibited $\alpha$-glucosidase and non-enzymatic glycation (Liu et al., 2020). Kim et al. (2019b) reported the anti-inflammatory activities of sinensetin on LPSstimulated L6 skeletal muscle by regulating NF- $\mathrm{kB}$.

Recently, the application of sinensetin as an active ingredient for preventing, ameliorating, or treating liver cancer or gastric cancer has been proposed (Kim and Lee, 2018; Patent No. KR20190050535A).

\section{Luteolin}

Sangeetha (2019) reported the antioxidant activity of luteolin and demonstrated how this polymethoxyflavone protects the pancreas and promotes insulin secretion. In addition, luteolin suppressed oxidative damage, lipid peroxidation, and increased antioxidant enzymes such as CAT and SOD (Xu et al., 2019). Antioxidant properties of luteolin are also proved in the central nervous system (CNS). The inhibition of gastric secretion and reduction of pepsin activity by luteolin was reported by Dai and Li (2018; Patent No. CN108309971B). In particular, the preparation includes 3-5 parts of luteolin and 1-2 parts of schisandrin $\mathrm{B}$ as active ingredients, and the dosage form of the compound preparation was preferably tablets, capsules, injections, and granules.

\section{Quercetin}

Quercetin has been used as a nutritional supplement and may have beneficial effects against a variety of diseases. Several in vitro and in vivo studies have evidenced its biological functions. Recently, Doustimotlagh et al. (2020) suggested the ability of quercetin $(50 \mathrm{mg} / \mathrm{kg} /$ day for 10 days) to cause a significant decrease in protein carbonyl, hydroxyproline, and to regulate the GPx activity. Therefore, quercetin acted as an enzyme inducer by renewing the glutathione peroxidase activity and inhibiting the oxidation of proteins, and hence decreases ROS production. These results confirmed the positive role of quercetin in attenuating the liver damage and degeneration. Milanezi et al. (2019) analyzed the antioxidant activity of quercetin-capped gold nanoparticles. Quercetin-capped gold nanoparticles $\left(\mathrm{IR}_{50} 0.37 \mu \mathrm{g} / \mathrm{mL}\right)$ exhibited greater activity than free quercetin $\left(\mathrm{IR}_{50} 0.57\right.$ $\mu \mathrm{g} / \mathrm{mL}$ ) by $\mathrm{NO}$ free radical scavenging assay.

Similarly, quercetin vesicular formulations (Eudragitcoated liposomes) were capable of ensuring optimal protection against oxidative stress in human intestinal cells by reducing ROS production, as reported by Caddeo et al. (2019). Its antioxidant capacities were correlated to the presence of two antioxidant pharmacophores in the molecule that had optimal configuration for free radical scavenging. The high antioxidant potential of quercetin was also confirmed in superoxide test with the $\mathrm{IC}_{50}$ values of $0.025 \mathrm{mM}$ versus $0.243 \mathrm{mM}$, for quercetin and kaempferol, respectively. Increasing in vivo studies have proved that quercetin acted as an antioxidant because of its ability to ameliorate antioxidant defenses, decrease free radical formation, and inhibit xanthine oxidase and lipid peroxidation (Shi et al., 2019).

Literatures data show that quercetin was able to reduce glucose levels when it was administered at a minimum dose of $30 \mathrm{mg} / \mathrm{kg}$ BW for 14 days (Yang and Kang, 2018). Additionally, this compound potentiated insulin secretion induced by glucose and glibenclamide and protected $\beta$-cells against oxidative damages (Shi et al., 2019). It was reported recently that the oral administration of quercetin $(25$ and $50 \mathrm{mg} / \mathrm{kg}$ ) for 28 days remarkably reduced the level of blood glucose, HbA1c, hepatic glycogen, and restored the activity of glucose-6-phosphatase and hexokinase in diabetic rats (Oyedemi et al., 2019). Eid et al. (2015) proposed the use of quercetin as an anti-diabetic compound, since this flavonoid could act through the stimulation of GLUT4 translocation in the skeletal muscle and the inhibition of glucose-6-phosphatase in hepatocytes.

In a human study of 12-week, Lee et al. (2016) used 100 $\mathrm{mg} /$ day/subject of quercetin to treat obesity and showed that this compound diminished the total body fat, and decreased the BMI of overweight or obese subjects. In 
addition, quercetin ameliorated mitochondrial functions in adipose tissue of HFD-induced obese mice by increasing the levels of oxidative stress-sensitive transcription factor and antioxidant enzymes (Kobori et al., 2016).

\section{Kaempferol}

The protective effect of kaempferol against oxidative stress in STZ-induced diabetic rats was evaluated by Al-Numair et al. (2015). Kaempferol administration (100 $\mathrm{mg} / \mathrm{kg} \mathrm{BW}$ ) to diabetic rats reduced plasma glucose, insulin, and lipid peroxidation products enzymatic such as SOD, CAT, GPX, and GSTs.

Another study (Alkhalidy et al., 2018) demonstrated that oral administration of kaempferol $(50 \mathrm{mg} / \mathrm{kg} /$ day than corresponding human equivalent dose of $240 \mathrm{mg} /$ day for $60 \mathrm{~kg}$ ) ameliorated blood glucose control in obese mice as well as reduced hepatic glucose production and improved insulin sensitivity. Additionally, these authors have found that kaempferol was a direct inhibitor of pyruvate carboxylase and suppressed gluconeogenesis in HepG2 cells. Torres-Villarreal et al. (2019) studied the kaempferol effects ( $60 \mu \mathrm{M}$ for 21 days) in order to evaluate its lipolytic and anti-adipogenic potential. The results of anti-obesity effects showed that kaempferol modulated adipogenic differentiation in 3T3-L1 cells through promoting downregulation of Cebpa gene expression and decreased lipid accumulation in mature adipocytes for its positive effects on Pnpla2 and Lipe mRNA levels.

\section{Rutin}

Rutin is considered a strong antioxidant agent; in fact, it acts as free radical scavenger, metal ions chelator, and reducing agent (Kaurinovic et al., 2019).

In STZ-induced diabetic rats, oral administration of 50 or $100 \mathrm{mg} / \mathrm{kg} \mathrm{BW}$ of this compound decreased fasting blood glucose as well as HbA1c levels. Moreover, chronic administration of $200 \mathrm{mg} / \mathrm{kg}$ BW of rutin reduced (30$40 \%)$ the prevalence of diabetes in STZ-treated mice (Ghorbani, 2017). In addition, rutin treatment $(50 \mathrm{mg} /$ $\mathrm{kg}$ ) for 24 weeks arrested the biochemical disturbances of diabetic retinopathy, lowering vascular endothelial growth factor (VEGF), TNF- $\alpha$, and increasing TAC in the retina (Gupta et al., 2019). This compound also acted in reducing adiposity, increasing energy expenditure, and improving glucose homeostasis in obese mice (Yuan et al., 2017).

The positive effects of rutin on lipid profile was also proved (Wang et al., 2015). Glucose and lipid metabolism are strictly correlated. The most important clinical manifestation of this interaction is diabetic dyslipidemia characterized by high level of TG, LDL, and VLDL. Rutin, among its antidiabetic effects, decreased serum levels of TG and VLDL, and increased the level of HDL. Additionally, rutin decreased ROS formation, advanced glycation end-product precursors, and production of inflammatory cytokines. The anti-inflammatory activity of rutin was recently confirmed by Su et al. (2019). Authors evidenced the inhibition of NF- $\mathrm{kB}$ pathway and understatement of endoplasmic reticulum stress.

\section{Phenolic acids}

Phenolic acids are a diverse class of phenolic compounds made by plants. They act as agents of plant defense, and are, indeed, immensely important in plant-microbe interactions/symbiosis (Mandal et al., 2010).

\section{Chlorogenic acid}

Chlorogenic acid is an important bioactive dietary polyphenol. Several studies have reported the ability of chlorogenic acid to act in metabolic disease through different mechanisms of action. Recently, use of chlorogenic acid in the treatment of metabolic disorders was proposed (Kodimule, 2018; Patent No. US20190111015A1).

Chlorogenic acid supplementation in hypercholesterolemic rats at a dose of 20 or $90 \mathrm{mg} / \mathrm{kg}$ BW for 12 weeks suppressed serum lipid levels, while a dosage of $10 \mathrm{mg} /$ $\mathrm{kg}$ significantly reduced total LDL-cholesterol and increased HDL-cholesterol by upregulating the expression of PPAR- $\gamma$ gene (Huang et al., 2015). Additionally, administration of chlorogenic acid at a dose of $80 \mathrm{mg} / \mathrm{kg}$ BW for 12 weeks decreased percentage of body fat, fasting plasma glucose, and HbA1c level via modulation of adiponectin receptor signaling pathways (Jin et al., 2015). Recently, Di Wang et al. (2019) reported that chlorogenic acid (100 mg/kg/day BW) taken for 4 weeks ameliorated the survival rate after myocardial infarction and demonstrated that this compound showed a protective effect on myocardial infarction by reducing inflammatory response, exerting antioxidant activity, and minimizing weight gain. Similarly, chlorogenic acid (100 or $150 \mathrm{mg}$ / day) reduced oxidative-induced damage and increased antioxidant protection in the inflamed paw skin, and reduced lipid peroxidation in serum (Mitrea et al., 2020). The effect of chlorogenic acid $(100 \mathrm{mg} / \mathrm{kg}$ BW for 13 weeks) on energy balance in obese mice has been studied recently (He et al., 2020). This compound reduced food intake, increased body temperature, thermal dissipation, brown adipose tissue activity, and improved glucose tolerance. The anti-obesity effect of chlorogenic acid was also observed in male Sprague-Dawley rats at a dose of 20 or $90 \mathrm{mg} / \mathrm{kg} \mathrm{BW}$ for 12 weeks (Huang et al., 2015). Oboh et al. (2015a) evaluated the inhibitory effects of chlorogenic acid on $\alpha$-amylase and $\alpha$-glucosidase enzymes. This compound showed the $\mathrm{IC}_{50}$ values of 9.10 $\mu \mathrm{g} / \mathrm{mL}$ and $9.24 \mu \mathrm{g} / \mathrm{mL}$ for $\alpha$-amylase and $\alpha$-glucosidase, 
respectively. Additionally, the same authors suggested its antioxidant properties with an $\mathrm{IC}_{50}$ value of $38.83 \mu \mathrm{g} / \mathrm{mL}$.

\section{Caffeic acid}

The antioxidant protection of caffeic acid and chlorogenic acid against oxidative stress was studied in vivo using BY4741 strain and SOD and glutathione-deficient mutants of S. cerevisiae (Prudêncio et al., 2019). In the cell viability tests, caffeic acid showed higher stress tolerance, with a 106\% increase in S. cerevisiae BY4741. However, in the SOD mutant, the effect of chlorogenic acid was stronger than caffeic acid, with a 3.3-fold increase. Conversely, in the glutathione-deficient mutant both treatments showed a similar level of protection. Arriagada et al. (2019) proposed the use of a hybrid nano-carrier consisting of core-shell silica nano-spheres linked to the surface with caffeic acid. These nano-spheres characterized by a potentiated antioxidant property accept the caffeic acid alone.

\section{Gallic acid}

Gallic acid was able to restore vitamin C and GSH levels in the pancreas of STZ-treated rats (Kahkeshani et al., 2019). Yang (2018; Patent No. CN108464949A) disclosed a kind of antioxidant lightening compositions and its applications. The antioxidant lightening compositions include element of orange peels (tangeretin) and gallic acid.

\section{Carotenoids}

Carotenoids are a group of natural tetraterpenoid pigments distributed widely in plants. They play essential roles: (a) in photosynthesis and photoprotection; (b) as precursors for the biosynthesis of phytohormones; and (c) as signaling molecules to mediate plant development and responses to environmental cues (Sun et al., 2018).

In humans, carotenoids were recognized for their biological activities associated with the reduction of risk of developing chronic diseases such as cancer, cardiovascular and neurodegenerative diseases as well as metabolic disease. Additionally, these compounds acted as antioxidants and protected the cells against free radicals formed in the tissues. Some of these compounds are vitamin A precursors (Cardoso et al., 2017).

$\beta$-Carotene (Figure 2) is an intense orange-colored pigment used as a food coloring agent (Milne, 2005). In nature, $\beta$-carotene is a vitamin A precursor, which is synthesized from carotenoids via the action of enzyme $\beta$-carotene 15,150-monooxygenase. The beneficial effects of $\beta$-carotene-fortified synbiotic food intake on metabolic status were studied in T2DM patients (Asemi et al., 2016). The $\beta$-carotene-fortified synbiotic food also contains Lactobacillus sporogenes $\left(1 \times 10^{7} \mathrm{CFU}\right), 0.1$-g inulin, and $0.05-\mathrm{g} \beta$-carotene. Results showed that this synbiotic food had favorable effects on homeostatic model assessment of insulin resistance, insulin, TG, VLDLcholesterol, and TC/HDL-cholesterol ratio, and NO and glutathione levels. Antioxidant immune response, and anti-inflammatory, anti-diabetic, and antitumor activities of $\beta$-carotene are also reported (Torregrosa-Crespo et al., 2018). In addition, existence of a positive effect of $\beta$-carotene on insulin sensitivity in obese patients through a positive regulation of adiponectin, either directly or via its pro-vitamin, was also suggested (Ben Amara et al., 2015).

Lutein ( $\beta, \varepsilon$-carotene-3,30-diol) acted as a powerful antioxidant, prevented HFD-induced atherosclerosis in apoE-deficient mice by inhibiting NADPH oxidase and increasing PPAR $-\gamma$ gene expression (Han et al., 2015). Additionally, it protects dopaminergic neurons against 1-methyl-4-phenyl-1,2,3,6-tetrahydropyridine (MPTP)induced apoptotic death and motor dysfunction by ameliorating mitochondrial disruption and oxidative stress (Nataraj et al., 2016).

$\beta$-Cryptoxanthin is used as a coloring agent for food products in certain countries. It is associated with the E number, E161C $\beta$-Cryptoxanthin, obtained from its common food sources. It exhibits high bioavailability, and $\beta$-cryptoxanthin-rich foods might be considered equivalent to $\beta$-carotene-rich foods as a source of retinol (Burri et al., 2016). Recently, Dhuique-Mayer et al. (2020) suggested that citrus $\times$ clementina juice enriched in $\beta$-cryptoxanthin $(43 \mu \mathrm{g} / \mathrm{g})$, hesperidin $(2,850 \mu \mathrm{g} / \mathrm{g})$, and pectin $(376 \mathrm{mg} / 100 \mathrm{~g})$ can be used for prevention of MS/T2DM. Moreover, the cancer preventive effects of $\beta$-cryptoxanthin have been described (Leoncini et al., 2016). The study included over 6,000 subjects with oral, laryngeal, and pharyngeal cancers. The treatment with $\beta$-cryptoxanthin determined a reduction of at least 18\% in the rate of oral and pharyngeal cancers and a reduction of $17 \%$ in the rate of laryngeal cancer.

Lycopene, one of most potent oxygen-quenching reagents among carotenoids, possessed the ability to inhibit the reactions initiated by free radicals, such as peroxy radicals or hydroxyl radicals. Indeed, cellular enzymes glutathione S-transferase, superoxide dismutase, and quinone reductase were activated by lycopene with consequent protection cells against ROS (Supatra, 2019). Owing to its antioxidant potential, lycopene (a) facilitated cell-to-cell communication at sites called "gap junctions" and consequently prevent cancer from developing; (b) stimulated the immune system; (c) regulated the endocrine communication pathways; and (d) regulated the cell reproductive cycle, preventing development of cancer (Supatra, 2019). Caseiro et al. (2020) also reported the ability of lycopene 
to protect lipids, proteins, and DNA from oxidative damage, and stimulate the modulation of cell growth and the expression of connexin 43, insulin-like growth factor-1 and/or blood levels of insulin-like growth factor-binding proteins, as well as intermediate levels in the immune system and inflammatory processes. In addition, lycopene improved insulin sensitivity through inhibition of signal transducer and activator of transcription 3/Srebp1c-mediated lipid accumulation and inflammation in mice fed with HFD (Zeng et al., 2017).

\section{Terpenes}

Terpenes are the largest class of natural products applied in industrial sector as flavors, fragrances, and spices as well as used in perfumery and cosmetics. In plants, these act as defense against biotic and abiotic stresses, or they are treated as signal molecules to attract insects for pollination (Singh and Sharma, 2015).

Ameh and Obodozie-Ofoegbu (2016) reported the utilization of citrus essential oil as flavorings in carbonated cola and citrus soft drinks. In particular, lemon-lime sodas contain Citrus limon, Citrus aurantifolia, and Citrus aurantium essential oils as main flavorings, while orange sodas contain Citrus aurantium oil as the main flavoring constituent.

The chemical variation of each component in citrus essential oil is based on variety, season, and geographical position as well as the ripening phase of the fruit (Bora et al., 2020). The major components are monoterpenes
(Figure 3), and D-limonene is the most abundant element. This monocyclic terpene is consumed by humans as an ingredient of traditional foods and is listed in the Code of Federal Regulations, as Generally Recognized as a Safe (GRAS) and used as a flavoring agent (Roberto et al., 2010).

The ameliorative effects of limonene on cadmium-induced genotoxicity in cultured human peripheral blood lymphocytes has been demonstrated recently (Verma et al., 2019). In this in vitro study, at concentrations of 20 and $100 \mathrm{Mm}$, it reduced the sister chromatid exchange frequency and peroxidation of lipids.

D-limonene reduced weight gain percentage, TC, LDL, and VLDL, and increased the level of HDL-cholesterol (Khan et al., 2019). In addition, the monoterpene (400 $\mathrm{mg} / \mathrm{kg}$ ) increased the levels of thiobarbituric acid (TBARS), SOD, CAT, and (GSH) in the liver tissue after treatment for 28 days. These results agreed with those reported by Yu et al. (2017); the authors observed how treatment with 50 or $100 \mathrm{mg} / \mathrm{kg}$ of D-limonene increased the levels of endogenous antioxidant enzymes. The treatment with limonene $(50 \mathrm{mg} / \mathrm{kg})$ displayed anti-inflammatory activity through decreasing TNF- $\alpha$, IL-6, and IL-1 $\beta$ levels and increasing the level of IL-10 (De Souza et al., 2019). Additionally, this compound determined reduction in gastric ulcer area (93\%) and myeloperoxidase activity. Increase in GPx activity was also observed. Limonene has also reported its ability to protect $\mathrm{PC} 12$ cells against corticosterone-induced neurotoxicity by activating the AMPK pathway (Tang et al., 2019). In fact, reductions were observed in MDA (a)

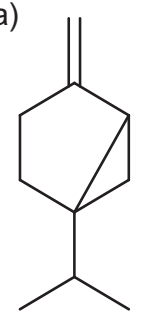

(b)<smiles>C=C(C)[C@H]1CC=C(C)CC1</smiles>

(c)

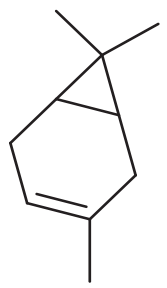

(d)<smiles>C=CC(C)(C)CCC=C(C)C</smiles>

(e)<smiles>C=C1CC/C=C(/C)CC[C@H]2[C@@H]1CC2(C)C</smiles>

Figure 3. Chemical structure of main monoterpenes of citrus essential oils: (a) sabinene, (b) limonene, (c) $\delta$-3-carene, (d) linalool, (e) $\beta$-caryophyllene. 
and NO levels, NADPH oxidase activity, iNOS, COX-2, IL-6, IL-1 $\beta$, TNF- $\alpha$, and expressions of pro-apoptotic proteins.

Another monoterpene found particularly abundant in citrus essential oil is sabinene which acts as a potential modulator of bacterial resistance. It could act in synergism with antibiotics to reduce MIC values against bacterial strains of PA03 and SA358 (Matias et al., 2016).

Linalool is an acyclic monoterpene tertiary alcohol (Figure 3) and is one of the most investigated aroma compounds. Currently, linalool and citral are mainly used as flavoring and natural preservatives due to their antimicrobial and antifungal ability. Indeed, they were used to extend the short shelf-life of seafood products and cheese because of their capacity to reduce populations of microorganisms, especially Enterobacteriaceae (Bora et al., 2020). At a concentrations of $0.1 \%$, linalool exhibited antimicrobial activity against different strains such as S. aureus, E. coli, B. subtilis, and Pasteurella multocida, with major activity against Gram-positive bacteria than Gram-negative bacteria.

Baldissera et al. (2017) evaluated the effect of $\beta$-caryophyllene on hypercholesterolemia in rats and the possible effect on hepatic antioxidant enzymes. Administration of $\beta$-Caryophyllene at a dose of $1.0 \mathrm{~mL} / \mathrm{kg}$ for 3 days reduced the levels of TC, LDL-cholesterol, and TG, inhibited the HMG-CoA reductase activity, and increased the antioxidant system of ROS and TBARS levels. These results agree with those reported by Basha and Sankaranarayanan (2016), who investigated the effect of $\beta$-caryophyllene on hyperglycemia. Oral administration of this compound $(200 \mathrm{mg} / \mathrm{kg} \mathrm{BW})$ for 45 days reduced the level of glucose and increased the level of insulin, with restored antioxidant status enhancing the activity of CAT, SOD, and GPx as well as inhibition of pro-inflammatory cytokines, TNF- $\alpha$ and IL-6. It has been recently demonstrated that $\beta$-caryophyllene reduced PGE2 and iNOS production and COX-2 expression ( $\mathrm{Hu}$ et al., 2017). Varga et al. (2018) have successively evidenced that at a dose of $10 \mathrm{mg} / \mathrm{kg} \mathrm{BW}$, this compound improved the chronic and binge alcohol-induced liver injury and inflammation by attenuating the pro-inflammatory phenotypic "M1" switch of Kupffer cells and diminishing the expression of E-Selectin, P-Selectin, and neutrophil infiltration. Additionally, it ameliorated the hepatic metabolic dysregulation, such as protein hyperacetylation, steatosis, and PPAR- $\gamma$ - gene signaling. These protective effects were correlated to activation of type- 2 cannabinoid receptor. Interaction with this receptor causes the expression of vascular cell adhesion molecule- 1 mediated by the JAK2/STAT1/IRF-1 pathway (Zhang et al., 2017).

\section{Conclusion}

A critical review of recent studies on the health properties of different portions of citrus fruits and their major bioactive compounds was reported. It was interesting to observe that not only the edible portion but also its by-products are characterized by high biological value. A large number of in vitro and in vivo studies have suggested an inverse relationship between increased consumption of citrus fruits and lowered risk of chronic diseases correlated to their large contents in polyphenols responsible for a wide range of beneficial effects in humans. The extraction of this bioactive compound, its addition to food, and development of nutraceuticals have gained increasing interest. In addition, citrus essential oils are frequently used as natural alternatives to synthetic preservatives for food safety, packaging, and preservation.

Interest in this plant genus is evidenced by the numerous patents and nutraceutical/pharmaceutical products already on the market for the prevention and treatment of numerous pathological conditions, including those related to metabolic disorders.

\section{References}

Abdallah E.M. 2020. Antibacterial potential of fresh fruit juices against multi-drug resistant pathogens. J Acute Dis. 9:83-88. https://doi.org/10.4103/2221-6189.281324

Aja P.M., Ekpono E.U., Awoke J.N., Famurewa A.C., Izekwe F.I., Okoro E.J., et al. 2020. Hesperidin ameliorates hepatic dysfunction and dyslipidemia in male Wistar rats exposed to cadmium chloride. Toxicol Rep. 7:1331-1338. https://doi.org/10.1016/j. toxrep.2020.09.014

Al-Aamri Maha S., Al-Abousi Nour M., Al-Jabri Sausan S., Alam T.K. and Shah A. 2018. Chemical composition and in-vitro antioxidant and antimicrobial activity of the essential oil of Citrus aurantifolia L. leaves grown in Eastern Oman. J Taibah Univ Med Sci. 13:108-112. https://doi.org/10.1016/j. jtumed.2017.12.002

Aladekoyi G., Omosulis V. and Orungbemi O. 2016. Evaluation of antimicrobial activity of oil extracted from three different citrus seeds (Citrus limon, Citrus aurantifolia and Citrus aurantium). Int. J. Sci. Res. Eng. Stud. 3:16-20.

Ali S. and Obaid Q. 2020. Lemon juice antioxidant activity against oxidative stress. Baghdad Sci J. 17:0207. https://doi. org/10.21123/bsj.2020.17.1(Suppl.).0207

Ali M.Y., Zaib S., Rahman M.M., Jannat S., Iqbal J., Park S.K. and Chang M.S. 2019. Didymin, a dietary Citrus flavonoid exhibits anti-diabetic complications and promotes glucose uptake through the activation of PI3K/Akt signaling pathway in insulinresistant HepG2 cells. Chemicobiol Interact. 305:180-194. https://doi.org/10.1016/j.cbi.2019.03.018

Alkhalidy H., Moore W., Wang A., Luo J., McMillan R.P., Wang Y., et al. 2018. Kaempferol ameliorates hyperglycemia through 
suppressing hepatic gluconeogenesis and enhancing hepatic insulin sensitivity in diet-induced obese mice. J. Nutr. Biochem. 58:90-101. https://doi.org/10.1016/j.jnutbio.2018.04.014.

Allam Sabbah M., El-Bedawy T.M., Bakr M.H. and Mahmoud A.E.M. 2020. Effect of feeding dried orange pulp to lactating dairy cows on nutrients digestibility, blood constituents, plasma antioxidant biomarker, and pathogenic fecal bacteria. Pakistan J Zool. 52:79-86. https://doi.org/10.17582/journal.pjz/2020.52.1.79.86

Al-Numair K.S., Chandramohan G., Veeramani C. and Alsaif M.A. 2015. Ameliorative effect of kaempferol, a flavonoid, on oxidative stress in streptozotocin-induced diabetic rats. Redox Rep. 20:198-209. https://doi.org/10.1179/1351000214Y.0000000117

Ameh S.J. and Obodozie-Ofoegbu O. 2016. Essential oils as flavorings in carbonated cola and Citrus soft drinks. London: Academic Press.

Amorim J.L., Simas D.L.R., Pinheiro M.M.G., Moreno D.S.A., Alviano C.S., Da Silva A.J.R., et al. 2016. Anti-inflammatory properties and chemical characterization of the essential oils of four Citrus species. PLoS ONE. 11:1-18. https://doi. org/10.1371/journal.pone.0153643

Ani P.N. and Ochu K.E. 2020. Anti-diabetic, anti-hyperlipidemic and hepatoprotective potential of shaddock (Citrus maxima) peel extract. Acta Sci Polon Technol Aliment. 19:271-278. https://doi.org/10.17306/J.AFS.2020.0811

Arriagada F., Günther G., Nos J., Nonell S., Olea-Azar C. and Morales J. 2019. Antioxidant nanomaterial based on core shell silica nanospheres with surface-bound caffeic acid: a promising vehicle for oxidation-sensitive drugs. Nanomaterials (Basel). 9:214-230. https://doi.org/10.3390/nano9020214

Arumugam A., Nagarani G., Srinivasan G., Saipriya V. and Siddhuraju P. 2019. Antidiabetic and hypolipidemic activities of peel and pulp extract from underutilized fruits of Citrus hystrix and Citrus maxima in streptozotocin-induced diabetic rats. Indian J. Environ. Edu. In press.

Asemi Z., Alizadeh S.A., Ahmad K., Goli M. and Esmaillzadeh A. 2016. Effects of beta-carotene fortified synbiotic food on metabolic control of patients with type 2 diabetes mellitus: A double-blind randomized cross-over controlled clinical trial. Clin Nutr. 35:819-825. https://doi.org/10.1016/j.clnu.2015.07.009

Azadeh H., Zarshenas M.M., Jamshidzadeh A, Heidari R. and Pasdaran A. 2019. Citrus aurantium (bitter orange) seed oil: pharmacognostic, anti-inflammatory, and anti-nociceptive properties. Trends Pharm Sc. 5:153-164. https://doi.org/10.30476/ TIPS.2019.82996.1020

Azhara S., Aryantib S. and Setiawanc B. 2020. Inhibition test of lemon juice (Citrus aurantifolia, Swingle) on the growth of Corynebacterium diphtheriae. J Xi'an Univ Arch Technol. 7:1359-1365.

Baldissera M.D., Souza C.F., Grando T.H., Doleski P.H., Boligon A.A., Stefani L.M. and Monteiro S.G. 2017. Hypolipidemic effect of $\beta$-caryophyllene to treat hyperlipidemic rats. NaunynSchmiedeberg Arch Pharmacol. 390:215-223. https://doi. org/10.1007/s00210-016-1326-3

Barberis A., Deiana M., Spissu Y., Azara E., Fadda A., Serra P., et al. 2020. Antioxidant, antimicrobial, and other biological properties of Pompia juice. Molecules. 25:3186. https://doi.org/10.3390/ molecules 25143186
Barreca D., Gattuso G., Bellocco E., Calderaro A., Trombetta D., Smeriglio A., et al. 2017. Flavanones: Citrus phytochemical with health-promoting properties. Biofactors. 43:495-506. https:// doi.org/10.1002/biof.1363

Basha R.H. and Sankaranarayanan C. 2016. $\beta$-Caryophyllene, a natural sesquiterpene lactone attenuates hyperglycemia-mediated oxidative and inflammatory stress in experimental diabetic rats. Chemicobiol Interact. 245:50-58. https://doi.org/10.1016/j. cbi.2015.12.019

Ben Amara N., Tourniaire F., Maraninchi M., Attia N., AmiotCarlin M.J., Raccah D., et al. 2015. Independent positive association of plasma $\beta$-carotene concentrations with adiponectin among non-diabetic obese subjects. Europ J Nutr. 54:447-454. https://doi.org/10.1007/s00394-014-0728-6

Bentahar A., Bouaziz A., Djidel S. and Khennouf S. 2020. Phenolic content and antioxidant activity of ethanolic extracts from Citrus sinensis L. and Citrus reticulata L. fruits. J. Drug Delivery Therap. 10:308-313. https://doi.org/10.22270/jddt.v10i5-s.4537

Bhuiyan F., Hasan M., Abdus M., Imran M., Sheikh R., Ahmed S., et al. 2019. Antimicrobial activity screening for three Citrus pulp extracts and phytochemical constituency profiling. J. Pharmacogn. Phytochem. 8:157-161. https://doi.org/10.5455/ jabet.2021.d103

Bonesi M., Loizzo M.R., Leporini M., Tenuta M.C., Passalacqua N.G. and Tundis R. 2018. Comparative evaluation of petitgrain oils from six Citrus species alone and in combination as potential functional antiradicals and antioxidant agents. Plant Biosyst. 152:986-993. https://doi.org/10.1080/11263504.2017.1403396

Bora H., Kamle M., Mahato D.K., Tiwari P. and Kumar P. 2020. Citrus essential oils (CEOs) and their applications in food: an overview. Plants. 9:357. https://doi.org/10.3390/plants9030357

Braga P.R., Bonilla J., Moro de Sousa R.L., Micke M.A. and Sampaio B.P. 2020. Chemical composition and antibacterial activity of essential oils against pathogens often related to cattle endometritis. J Infect Develop Countries. 14:177-183. https:// doi.org/10.3855/jidc.12076

Brasili E., Hassimotto N.M.A., Del Chierico F., Marini F., Quagliariello A., Sciubba F., et al. 2019. Daily consumption of orange juice from Citrus sinensis L. Osbeck cv. Cara Cara and cv. Bahia differently affects gut microbiota profiling as unveiled by an integrated meta-omics approach. J Agricul Food Chem. 67:1381-1391. https://doi.org/10.1021/acs.jafc.8b05408

Buket A., Zorba D., Nilüfer N. and Yllmaz E. 2018. Antimicrobial activity of cold pressed citrus seeds oils, some Citrus flavonoids and phenolic acids. Rivista Italiana Delle Sostanze Grasse. 95:119-131.

Burri B.J., La Frano M.R., and Zhu C. 2016. Absorption, metabolism, and functions of $\beta$-cryptoxanthin. Nutr Rev. 74:69-82. https://doi.org/10.1093/nutrit/nuv064

Caddeo C., Gabriele M., Fernàndez-Busquets X., Valenti D., Fadda A.M., Pucci L. and Manconi M. 2019. Antioxidant activity of quercetin in Eudragit-coated liposomes for intestinal delivery. Int J Pharm. 565:64-69. https://doi.org/10.1016/j. ijpharm.2019.05.007

Cardile V., Graziano A.C.E. and Venditti A. 2015. Clinical evaluation of Moro (Citrus sinensis (L.) Osbeck) orange juice 
supplementation for the weight management. Nat Prod Res. 29:2256-2260. https://doi.org/10.1080/14786419.2014.1000897

Cardoso L.A.C., Karp S.G., Vendruscolo F., Kanno K.Y.F., Zoz L.I.C. and Carvalho J.C. 2017. Chapter 8. Biotechnological production of carotenoids and their applications in food and pharmaceutical products. In: Dragan J. Cvetkovic and Goran S. Nikolic (Eds.), Carotenoids,. InTechOpen, London. https://doi. org/10.5772/67725

Casacchia T., Occhiuzzi M.A., Grande F., Rizzuti B., Granieri M.C., Rocca C., et al. 2019. Pilot study on the nutraceutical properties of the Citrus hybrid Tacle as a dietary source of polyphenols for supplementation in metabolic disorders. J Funct Foods. 52:370381. https://doi.org/10.1016/j.jff.2018.11.030

Caseiro M, Ascenso A., Costa A., Creagh-Flynn J., Johnson M., and Simões S. 2020. Lycopene in human health. LWT. 127:109323. https://doi.org/10.1016/j.lwt.2020.109323

Chen X.M., Tait A.R. and Kitts D.D. 2017. Flavonoid composition of orange peel and its association with antioxidant and antiinflammatory activities. Food Chem. 218:15-21. https://doi. org/10.1016/j.foodchem.2016.09.016

Chen G. and Wang H. 2015. Application of nobiletin. Patent No. CN105030559A (China).

Chen Q., Wang D., Tan C., Hu Y., Sundararajan B. and Zhou Z. 2020. Profiling of flavonoid and antioxidant activity of fruit tissues from 27 Chinese local citrus cultivars. Plants (Basel, Switzerland). 9:196. https://doi.org/10.3390/plants9020196

Chi P.T.L., Van Hung P., Le Thanh H. and Phi N. 2020. Valorization of Citrus leaves: chemical composition, antioxidant and antibacterial activities of essential oils. Waste Biomass Valorization. 11:4849-4857. https://doi.org/10.1007/s12649-019-00815-6

Chilaka K.C., Ifediba E.C. and Ogamba J.O. 2015. Evaluation of the effects of Citrus sinensis seed oil on blood glucose, lipid profile and liver enzymes in rats injected with alloxan monohydrate. J Acute Dis. 4:129-134. https://doi.org/10.1016/ S2221-6189(15)30022-6

Cho Y.G., Jung J.H., Kang J.H., Kwon J.S., Yu S.P. and Baik T.G. (2017). Effect of a herbal extract powder (YY-312) from Imperata cylindrica Beauvois, Citrus unshiu Markovich, and Evodia officinalis Dode on body fat mass in overweight adults: a 12-week, randomized, double-blind, placebo-controlled, parallel-group clinical trial. BMC Complement Altern Med, 17:375. https://doi. org/10.1186/s12906-017-1871-4

Cilla A., Rodrigo M.J., Zacarías L., De Ancos B., Sánchez-Moreno Citrus, Barberá R., et al. 2018. Protective effect of bioaccessible fractions of Citrus fruit pulps against $\mathrm{H}_{2} \mathrm{O}_{2}$-induced oxidative stress in Caco-2 cells. Food Res Int. 103:335-344. https://doi. org/10.1016/j.foodres.2017.10.066

Costanzo G., Iesce M.R., Naviglio D., Ciaravolo M., Vitale E. and Arena C. 2020. Comparative studies on different Citrus cultivars: a revaluation of waste mandarin components. Antioxidants. 9:51. https://doi.org/10.3390/antiox9060517

Cyndi B., Andriane Y. and Nur I.M. 2016. Pengaruh pemberian ekstrak etanol daun jeruk nipis (Citrus aurantifolia swingle) terhadap penurunan kadar kolesterol total darah pada mencit model hyperkolesterolemia. Prosiding Pendidikan Dokter. 2:911-918. https://doi.org/10.29313/kedokteran.v0i0.4414
Dai Y. and Li C. 2018. Luteolin compound preparation and application thereof in inhibiting gastric secretion. Patent No. CN108309971B (China).

Da Silva E.S., Oliveira B.G., Pereira A.C.H., Pimentel E.F., Pezzuto J.M., Lenz D., et al. 2018. Induction of $\mathrm{NAD}(\mathrm{P}) \mathrm{H}$ : quinone reductase $1(\mathrm{QR} 1)$ and antioxidant activities in vitro of "Toranja Burarama" (Citrus maxima [Burm.]Merr.). Phytother Res. 32:2059-2068. https://doi.org/10.1002/ptr.6149

Değirmenci H. and Erkurt H. 2020. Relationship between volatile components, antimicrobial and antioxidant properties of the essential oil, hydrosol and extracts of Citrus aurantium L. flowers. J Infec Public Health. 13:58-67. https:// doi.org/10.1016/j.jiph.2019.06.017

De Leo M., Piragine E., Pirone A., Braca A., Pistelli L., Calderone V., et al. 2020. Protective effects of bergamot (Citrus bergamia risso \& poiteau) juice in rats fed with high-fat diet. Planta Med. 86:180189. https://doi.org/10.1055/a-1070-9325

Demir A. and Celik I. 2019. Investigation of healing effects of lemon (Citrus limonum) seeds lyophilized extracts on experimental diabetic rats. Arch Physiol Biochem. 12:1-8. https://doi.org/10 $.1080 / 13813455.2019 .1702061$

De Oliveira Filho J.G., de Deus I.P.B., Valadares A.C.F., Fernandes C.C., Estevam E.B.B. and Egea M.B. 2020. Chitosan film with Citrus limonia essential oil: physical and morphological properties and antibacterial activity. Colloids Interfac. 4:18. https://doi.org/10.3390/colloids4020018

De Souza V.T., de Franco É.P., de Araújo M.E., Messias M.C., Priviero F.B., Frankland Sawaya A.C., et al. 2016. Characterization of the antioxidant activity of aglycone and glycosylated derivatives of hesperetin: an in vitro and in vivo study. J Mol Recog. 29:80-87. https://doi.org/10.1002/jmr.2509

De Souza M.C., Vieira A.J., Beserra F.P., Pellizzon C.H., Nóbrega R.H. and Rozza ALL 2019. Gastroprotective effect of limonene in rats: influence on oxidative stress, inflammation and gene expression. Phytomedicine. 53:37-42. https://doi. org/10.1016/j.phymed.2018.09.027

Denkova-Kostova R., Teneva D., Tomova T., Goranov B., Denkova Z., Shopska V., et al. 2020. Chemical composition, antioxidant and antimicrobial activity of essential oils from tangerine (Citrus reticulata L.), grapefruit (Citrus paradisi L.), lemon (Citrus lemon L.) and cinnamon (Cinnamomum zeylanicum Blume). Z Naturforsch C J. Biosci. 76:175-185. https://doi. org/10.1515/znc-2020-0126

Dhanya R. and Jayamurthy P. 2020. In vitro evaluation of antidiabetic potential of hesperidin and its aglycone hesperetin under oxidative stress in skeletal muscle cell line. Cell Biochem. Function. 38:419-427. https://doi.org/10.1002/cbf.3478

Dhuique-Mayer C., Gence L., Portet K., Tousch D. and Poucheret P. 2020. Preventive action of retinoids in metabolic syndrome/ type 2 diabetic rats fed with citrus functional food enriched in $\beta$-cryptoxanthin. Food Funct. 11:9263-9271. https://doi. org/10.1039/d0fo02430a

Diab K.A., Shafik R.E. and Yasuda S. 2015. In vitro antioxidant and antiproliferative activities of novel orange peel extract and its fractions on leukemia HL-60 cells. Asian Pacific J Cancer Prevent. 16:7053-7060. https://doi.org/10.7314/APJCP.2015.16.16.7053 
Di Folco U., Pollakova D., De Falco D., Nardone M.R., Tubili F. and Tubilia C. 2018. Effects of a nutraceutical multicompound including bergamot (Citrus Bergamia Risso) juice on metabolic syndrome: a pilot study. Mediterranean J Nutr Metabol. 11:119126. https://doi.org/10.3233/MNM-17186

Dinesh S. and Hegde K. 2016. Antiobesity activity of ethanolic extract of Citrus maxima leaves on cafeteria diet induced and drug induced obese rats. Res J Pharm Technol. 9:907. https:// doi.org/10.5958/0974-360X.2016.00173.6

Doustimotlagh A.H., Taheri S., Mansourian M. and Eftekharie M. 2020. Extraction and identification of two flavonoids in Phlomoides hyoscyamoides as endemic plant of Iran: the role of quercetin in the activation of the glutathione peroxidase, the improvement of the hydroxyproline and protein oxidation in bile duct-ligated rats. Curr Comp Aided Drug Design. 16:629640. https://doi.org/10.2174/1573409915666190903163335

Eghtesadi S., Mohammadi M., Vafa M., Heidari I., Salehi M., Haghighian H.K., et al. 2016. Effects of hesperidin supplementation on glycemic control, lipid profile and inflammatory factors in patients with type 2 diabetes: a randomized, double-blind and placebo-controlled clinical trial. Endocr Abst. 43:OC16. https:// doi.org/10.1530/endoabs.43.OC16

Eid H.M., Nachar A., Thong F., Sweeney G. and Haddad P.S. 2015. The molecular basis of the antidiabetic action of quercetin in cultured skeletal muscle cells and hepatocytes. Pharmacog Mag. 11:74-81. https://doi.org/10.4103/0973-1296.149708

Ernawita Z., Wahyuono R., Hesse-Macabata J., Hipler U.C., Elsner P. and Böhm V. 2016. Carotenoids of indigenous citrus species from Aceh and its in vitro antioxidant, antidiabetic and antibacterial activities. European Food Res Technol. 242:1869-1881. https://doi.org/10.1007/s00217-016-2686-0

Ernawita Z., Wahyuono R.A., Hesse J., Hipler U.C., Elsner P. and Böhm V. 2017. In vitro lipophilic antioxidant capacity, antidiabetic and antibacterial activity of citrus fruits extracts from Aceh, Indonesia. Antioxidants. 6:11-26. https://doi.org/10.3390/ antiox6010011

Eryllmaz M., Cicek P.D., Akalın K. and Coskun M. 2018. Antimicrobial activity of grapefruit seed. Hacettepe Univ J Faculty Pharm. 38:1-3.

Fadillah Q., Chiuman L., Ginting C., and Girsang E. 2020. Effectiveness test of anti-bacterial lime juice (Citrus aurantifolia) on salmonella sp bacteria in salmon fish (Oncorhynchus nerka). BIOLINK (J Biol Lingkungan Industri Kesehatan). 7:8189. https://doi.org/10.31289/biolink.v7i1.3322

Falcinelli B., Famiani F., Paoletti A., D'Egidio S., Stagnari F., Galieni A., et al. 2020. Phenolic compounds and antioxidant activity of sprouts from seeds of Citrus species. Agriculture. 10:33. https://doi.org/10.3390/agriculture10020033

Fancello F., Petretto G.L., Marceddu S., Venditti T., Pintore G., Zara G., et al. 2020. Antimicrobial activity of gaseous Citrus limon var pompia leaf essential oil against Listeria monocytogenes on ricotta salata cheese. Food Microbiol. 87:103386. https://doi. org/10.1016/j.fm.2019.103386

Farahmandfar R., Tirgarian B., Dehghan B. and Nemati A. 2020. Comparison of different drying methods on bitter orange (Citrus aurantium L.) peel waste: changes in physical (density and color) and essential oil (yield, composition, antioxidant and antibacterial) properties of powders. J Food Meas Characterization. 14:862-875. https://doi.org/10.1007/s11694-019-00334-x

Farooqi A.A., Wang Z., Hasnain S., Attar R., Aslam A., Mansoor Q., et al. 2015. Citrus fruits and their bioactive ingredients: leading four horsemen from front. Asian Pacific J Cancer Prevent. 16:2575-2580. https://doi.org/10.7314/apjcp.2015.16.6.2575

Favela-Hernández J.M.J., González-Santiago O., RamírezCabrera M.A., Esquivel-Ferriño P.C. and del Rayo CamachoCorona M. 2016. Chemistry and pharmacology of Citrus sinensis. Molecules. 21:247-271. https://doi.org/10.3390/molecules 21020247

Fayek N.M., El-Shazly A.H., Abdel-Monem A.R., Mohamed M.Y., Abd-Elwahab S.M. and El-Tanbouly Nebal D. 2017. Comparative study of the hypocholesterolemic, antidiabetic effects of four agro-waste citrus peels cultivars and their HPLC standardization. Revista Brasileira de Farmacognosia. 27:488-494. https:// doi.org/10.1016/j.bjp.2017.01.010

Ferreira P.S., Spolidorio L.C., Mantheyc J.A. and Cesar T.B. 2016. Citrus flavanones prevent systemic inflammation and ameliorate oxidative stress in C57BL/6J mice fed high-fat diet. Food Function. 7:2675-2681. https://doi.org/10.1039/C5FO01541c

Fidélix M., Milenkovic D., Sivieri K. and Cesar T. 2020. Microbiota modulation and effects on metabolic biomarkers by orange juice: a controlled clinical trial. Food \& Funct. 11:1599-1610. https://doi.org/10.1039/c9fo02623a

Fratianni F., Cozzolino A., De Feo V., Coppola R., Ombra M.N. and Nazzaro F. 2019. Polyphenols, antioxidant, antibacterial, and biofilm inhibitory activities of peel and pulp of Citrus medica L., Citrus bergamia, and Citrus medica cv. Salò cultivated in southern Italy. Molecules. 24:4577. https://doi.org/10.3390/ molecules 24244577

Gao Y., Xu D., Ren D., Zeng K. and Wu X. 2020. Green synthesis of zinc oxide nanoparticles using Citrus sinensis peel extract and application to strawberry preservation: A comparison study. LWT Food Sci Technol. 126:109297. https://doi.org/10.1016/j. lwt.2020.109297

Gavarić N., Kovac J., Kretschmer N., Kladar, N., Smole M.S., Bucar, F., et al. 2015. Natural products as antibacterial agentsantibacterial potential and safety of post-distillation and waste material from Thymus vulgaris L., Lamiaceae. In: Concepts, compounds and the alternatives of antibacterials. InTech, London, pp. 123-151. https://doi.org/10.5772/60869

Ghorbani A. 2017. Mechanisms of antidiabetic effects of flavonoid rutin. Biomed Pharmacother. 96:305-312. https://doi. org/10.1016/j.biopha.2017.10.001

Gironés-Vilaplana A., Valentão P., Andrade P.B., Ferreres F., Moreno D.A. and García-Viguera C. 2015. Beverages of lemon juice and exotic noni and papaya with potential for anticholinergic effects. Food Chem. 170:16-21. https://doi.org/10.1016/j. foodchem.2014.08.021

Guo J., Gao Z., Xia J., Ritenour M., Li G. and Shan Y. 2018. Comparative analysis of chemical composition, antimicrobial and antioxidant activity of Citrus essential oils from the main cultivated varieties in China. LWT Food Sci Technol. 97:825839. https://doi.org/10.1016/j.lwt.2018.07.060 
Guo C., Shan Y., Yang Z., Zhang L., Ling W., Liang Y., Ouyang Z., Zhong B. and Zhang J. 2020. Chemical composition, antioxidant, antibacterial, and tyrosinase inhibition activity of extracts from Newhall navel orange (Citrus sinensis Osbeck cv. Newhall) peel. J Sci Food Agricul. 100:2664-2674. https://doi.org/10.1002/ jsfa.10297

Guo J., Tao H., Cao Y., Ho C.T., Jin S. and Huang Q. 2016. Prevention of obesity and Type 2 diabetes with aged Citrus peels (chenpi) extract. J Agricul Food Chem. 64:2053-2061. https://doi. org/10.1021/acs.jafc.5b06157

Gupta S.K., Sharma H.P., Das U., Velpandian T. and Saklani R. 2019. Effect of rutin on retinal VEGF, TNF- $\alpha$, aldose reductase, and total antioxidant capacity in diabetic rats: molecular mechanism and ocular pharmacokinetics. Int Ophthalmol. 40:159-168. https://doi.org/10.1007/s10792-019-01165-x

Haidari F., Heybar H., Jalali M.T., Ahmadi Engali K., Helli B. and Shirbeigiet E. 2015. Hesperidin supplementation modulates inflammatory responses following myocardial infarction. J Amer Coll Nutr. 34:205-211. https://doi.org/10.1080/07315724.2014.891269

Hamdan D., El-Shiekh R., El-Sayed M., Khalil H., Mousa M., Al-Gendy A. and El Sahzly A. 2020. Phytochemical characterization and anti-inflammatory potential of Egyptian Murcott Mandarin cultivar waste (stem, leaves and peel). Food Funct. 11:8214-8236. https://doi.org/10.1039/D0FO01796E

Han H., Cui W., Wang L., Xiong Y., Liu L., Sun X. and Hao L. 2015. Lutein prevents high fat diet-induced atherosclerosis in ApoEdeficient mice by inhibiting NADPH oxidase and increasing PPAR expression. Lipids. 50:261-273. https://doi.org/10.1007/ s11745-015-3992-1

Haraoui N., Allem R., Mohammed Chaouche T. and Belouazni A. 2020. In vitro antioxidant and antimicrobial activities of some varieties Citrus grown in Algeria. Adv Trad Med. 20:23-34. https://doi.org/10.1007/s13596-019-00379-9

He B., Nohara K., Park N., Park Y.S., Guillory B., Zhao Z., et al. 2016. The small molecule nobiletin targets the molecular oscillator to enhance circadian rhythms and protect against metabolic syndrome. Cell Metabol. 23:610-621. https://doi.org/10.1016/j.cmet.2016.03.007

He X., Zheng S., Sheng Y., Miao T., Xu J., Xu W., et al. 2020. Chlorogenic acid ameliorates obesity by preventing energy balance shift in high-fat diet induced obese mice. J Sci Food Agricul. 19: 631-637. https://doi.org/10.1002/jsfa.10675

Homayouni F., Haidari F., Hedayati M., Zakerkish M. and Ahmadi K. 2017. Hesperidin supplementation alleviates oxidative DNA damage and lipid peroxidation in type 2 diabetes: a randomized double-blind placebo-controlled clinical trial. Phytother Res. 31:1539-1545. https://doi.org/10.1002/ptr.5881

Hsouna A., Gargouri M., Dhifi W., Ben S.R., Sayahi N., Mnif W. and Saibi W. 2018. Potential anti-inflammatory and antioxidant effects of Citrus aurantium essential oil against carbon tetrachloride-mediated hepatotoxicity: a biochemical, molecular and histopathological changes in adult rats. Environ Toxicol. 34:388-400. https://doi.org/10.1002/tox.22693

Hsu Y.L., Hsieh C.J., Tsai E.M., Hung JY., Chang W.A., Hou M.F., et al. 2016. Didymin reverses phthalate ester-associated breast cancer aggravation in the breast cancer tumor microenvironment. Oncol Lett. 11:1035-1042. https://doi.org/10.3892/ol.2015.4008
Hu Y., Zeng Z., Wang B. and Guo S. 2017. Trans-caryophyllene inhibits amyloid $\beta(A \beta)$ oligomer-induced neuroinflammation in BV-2 microglial cells. Int Immunopharmacol 51:91-98. https:// doi.org/10.1016/j.intimp.2017.07.009

Huang K., Liang X.C., Zhong Y.L., He W.Y. and Wang Z. 2015. 5-Caffeoylquinic acid decreases diet-induced obesity in rats by modulating PPAR $\alpha$ and LXR $\alpha$ transcription. J Sci Food Agricul. 95:1903-1910. https://doi.org/10.1002/jsfa.6896

Huang R., Zhang Y., Shen S., Zhi Z., Cheng H., Chen S., et al. 2020. Antioxidant and pancreatic lipase inhibitory effects of flavonoids from different citrus peel extracts: an in vitro study. Food Chem. 326:126785. https://doi.org/10.1016/j.foodchem.2020.126785

Ibrahim F., Usman L., Akolade J., Idowu O., Abdulazeez A. and Amuzat A. 2019. Antidiabetic potentials of Citrus aurantifolia leaf essential oil. Drug Res. 69: 201-206. https://doi. org/10.1055/a-0662-5607

Ikoma Y., Matzsumoto H. and Kato M. 2016. Diversity in the carotenoid profiles and the expression of genes related to carotenoid accumulation among citrus genotypes. Breed Sci. 66:139-147. https://doi.org/10.1270/jsbbs.66.139

Impellizzeri D., Bruschetta G., di Paola R., Ahmad A., Campolo M., Cuzzocrea S., et al. 2015. The anti-inflammatory and antioxidant effects of bergamot juice extract (BJe) in an experimental model of inflammatory bowel disease. Clin Nutr. 34:1146-1154. https://doi.org/10.1016/j.clnu.2014.11.012

İnan Ö., Özcan M.M. and Aljuhaimi F. 2018. Effect of location and Citrus species on total phenolic, antioxidant, and radical scavenging activities of some Citrus seed and oils. J Food Proc Pres 42:e13555. https://doi.org/10.1111/jfpp.13555

Itoh K., Matsukawa T., Murata K., Nishitani R., Yamagami M., Tomohiro N., et al. 2019. Pancreatic lipase inhibitory activity of Citrus unshiu leaf extract. Nat Prod Comm. 14:Art. No. 1934578X1987343. https://doi.org/10.1177/1934578X19873439

Jayaraman R., Subramani S., Sheik Abdullah S.H. and Udaiyar M. 2018. Antihyperglycemic effect of hesperetin, a Citrus flavonoid, extenuates hyperglycemia and exploring the potential role in antioxidant and antihyperlipidemic in streptozotocin-induced diabetic rats. Biomed Pharmacother. 97:98-106. https://doi. org/10.1016/j.biopha.2017.10.102

Jia S., Hu Y., Zhang W., Zhao X., Chen Y., Sun C., et al. 2015. Hypoglycemic and hypolipidemic effects of neohesperidin derived from Citrus aurantium L. in diabetic KK-A(y) mice. Food Funct. 6:878-86. https://doi.org/10.1039/c4fo00993b

Jin S., Chang C., Zhang L., Liu Y., Huang X. and Chen Z. 2015. Chlorogenic acid improves late diabetes through adiponectin receptor signaling pathways in $\mathrm{db} / \mathrm{db}$ mice. PLoS One. 10:e0120842. https://doi.org/10.1371/journal.pone.0120842.

Kahkeshani N., Farzaei F., Fotouhi M., Alavi S.S., Bahramsoltani R., Naseri R., et al. (2019). Pharmacological effects of gallic acid in health and diseases: A mechanistic review. Iran J Basic Med Sci. 22:225-237. https://doi.org/10.22038/ijbms.2019.32806.7897

Kamel I.H., Salib J.Y., El-Toumy S.A., Awad A.H. and Elmenabbawy M.K. 2019. Citrus reticulata peel extract: an anti-obesity therapy for adolescents. Middle East J Appl Sci Technol. 9:117-124

Kang S.I., Shin H.S., and Kim S.J. 2015. Sinensetin enhances adipogenesis and lipolysis by increasing cyclic adenosine 
monophosphate levels in 3T3-L1 adipocytes. Bio Pharmaceut Bull. 38:552-558. https://doi.org/10.1248/bpb.b14-00700

Kasim V.N., Hatta M., Natzir R., Hadju V., Hala Y., Budu B., et al. 2020. Antibacterial and anti-inflammatory effects of lime (Citrus aurantifolia) peel extract in mice balb/c induced salmonella typhi. J Bio Res93:2. https://doi.org/10.4081/jbr.0.8951

Kaur J. 2014. A comprehensive review on metabolic syndrome. Cardiol Res Pract. 2014:943162. https://doi.org/10.1155/ 2014/943162

Kaurinovic B. and Vastag D. 2019. Chapter 5. Flavonoids and phenolic acids as potential natural antioxidants. In: Shalaby, E. (ed.) Antioxidants. IntechOpen, London, pp. 1-20. https://doi. org/10.5772/intechopen.83731

Kegele C.S., Oliviera J., Magrani T., Ferreira A., de Souza R., Sabbaghi A., et al. 2019. A randomized trial on the effects of CitrusiM $^{\circ}$ (Citrus sinensis (L.) Osbeck dried extract) on body composition. Clin Nutr Exp. 27:29-36. https://doi.org/10.1016/j. yclnex.2019.08.002

Khan A., Ikram M., Hahm J.R. and Kim M.O. 2020. Antioxidant and anti-inflammatory effects of Citrus flavonoid hesperetin: special focus on neurological disorders. Antioxidants. 9:609. https://doi. org/10.3390/antiox9070609

Khan A., Siddiqui H., Mahmood T. and Ahsan F. 2019. A comparative evaluation study of Citrus limetta and metformin against hyperlipidemia in diabetic and non-diabetic rats. Res J Pharm Technol. 12:1244-1250. https://doi. org/10.5958/0974-360X.2019.00207.5

Khettal B., Kadri N., Tighilet K., Adjebli A., Dahmoune F. and Maiza-Benabdeslam F. 2017. Phenolic compounds from Citrus leaves: antioxidant activity and enzymatic browning inhibition. J Complement Integ Med. 14:1-6. https://doi.org/10.1515/ jcim-2016-0030

Khidr A., Elshazly S., Elfayoumy H. and El-Maraghy N.N. 2020. Protective effect of hesperidin modulates inflammatory response, oxidative stress status and blood pressure following renal artery stenosis in rats. Zagazig Univ Med J. In press. https://doi.org/10.21608/ZUMJ.2020.27909.1813

Kim G.N., Shin M.R., Shin S.H., Lee A.R., Lee J.Y., Seo B.I., et al. (2016). Study of Antiobesity Effect through Inhibition of Pancreatic Lipase Activity of Diospyros kaki Fruit and Citrus unshiu Peel. Biomed Res Int. 2016:1723042. https://doi. org/10.1155/2016/1723042

Kim G. and Lee S. 2018. Composition for prevention, improvement or treatment of liver cancer or stomach cancer comprising sinensetin as active ingredient., Patent No. KR20190050535A (Korea).

Kim J.A., Ha S.E., Kim S.M., Vetrivel P., Kim G.S. and Kim E.H. 2019a. Anti-inflammatory activities of sinensetin on LPSstimulated L6 skeletal muscle cells. J Biomed Translat Res. 20:17. https://doi.org/10.12729/jbtr.2019.20.1.001

Kim C., Ji J., Baek S.H., Lee J.H., Ha I.J., Lim S.S., et al. 2019b. Fermented dried Citrus unshiu peels extracts exert antiinflammatory activities in LPS-induced RAW264.7 macrophages and improve skin moisturizing efficacy in immortalized human HaCaT keratinocytes. Pharmaceut Bio. 57:392-402. https://doi.org/10.1080/13880209.2019.1621353
Kim D.S. and Lim S.B. 2020. Semi-continuous subcritical water extraction of flavonoids from citrus unshiu peel: their antioxidant and enzyme inhibitory activities. Antioxidants. 9:360-376. https://doi.org/10.3390/antiox9050360

Kirtikar S., Himangshu S., Ashish S. and Kota V.R. 2018. Didymin prevents hyperglycemia-induced human umbilical endothelial cells dysfunction and death. Biochem Pharmacol. 152:1-10. https://doi.org/10.1016/j.bcp.2018.03.012

Ko E.A., Seung-Hee N., Hana J., Bo Y.K., Sang H.K., Sunyoung K., et al. 2020. Antioxidant, anti-inflammatory and anti-allergenic effects of Citrus junos seed oil and its human skin protection. J Soc Cosm Scientists Korea. 46:283-294. https://doi. org/10.15230/SCSK.2020.46.3.283

Kobayashi H., Mitani M., Minatogawa Y., Hayashi S., Nakamoto M., Shuto E., et al. 2017. Extracts of Citrus Sudachi peels attenuate body weight gain in C57BL/6 mice fed a high-fat diet. J Med Invest. 64:20-23. https://doi.org/10.2152/jmi.64.20

Kobori M., Takahashi Y., Sakurai M., Akimoto Y., Tsushida T., Oike H., et al. 2016. Quercetin suppresses immune cell accumulation and improves mitochondrial gene expression in adipose tissue of diet-induced obese mice. Mol Nutr and Food Res. 60:300-312. https://doi.org/10.1002/mnfr.201500595

Kodimule S.P. 2018. Chlorogenic acid composition for the treatment of metabolic disorders. Patent No. US20190111015A1 (United States).

Kometsi L., Govender K., Mato-Mofo E., Hurchund R. and Owira P. 2020. By reducing oxidative stress, naringenin mitigates hyperglycaemia-induced upregulation of hepatic nuclear factor erythroid 2-related factor 2 protein: naringenin and hepatic Nrf2 protein expression. J Pharm Pharmacol. 72:1394-1404. https:// doi.org/10.1111/jphp.13319

Konglong F., Zhu X., Liu G., Kan Q., Chen T., Chen Y., et al. 2020. Dietary Citrus peel essential oil ameliorates hypercholesterolemia and hepatic steatosis by modulating lipid and cholesterol homeostasis. Food Funct. 11:7217-7230. https://doi. org/10.1039/D0FO00810A

Kumar P., Sharma H., Dev K., Rana A.C. and Kumar S. 2019. Preclinical studies of the lemon hill as a multiapproach antioxidant and antidiabetic plant: Citrus pseudolimon tanaka. J Herbs Spices Med Plants. 25:69-87. https://doi.org/10.1080/10496475 2019.1570994

Kumar K., Yadav A.N., Kumar V., Vyas P. and Dhaliwal H.S. 2017. Food waste: a potential bioresource for extraction of nutraceuticals and bioactive compounds. Bioresour Bioproc. 4:1-14. https://doi.org/10.1186/s40643-017-0148-6

Kusumawardhani N., Thuraidah A. and Nurlailah N. 2020. Citrus hystrix D.C juice inhibits the growth of Staphylococcus aureus. Tropical Health Med Res. 2:34-38. https://doi. org/10.35916/thmr.v0i0.17.

Kwon E.Y. and Choi M.S. 2020. Eriocitrin improves adiposity and related metabolic disorders in high-fat diet-induced obese mice. J Med Food. 23:233-241. https://doi.org/10.1089/jmf.2019.4638

Lala M., Modak D., Paul S., Sarkar I., Dutta A., Bhattacharjee S., et al. 2020. Potent bioactive methanolic extract of wild orange (Citrus macroptera Mont.) shows antioxidative, antiinflammatory, and antimicrobial properties in in vitro, in vivo, 
and in silico studies. Bull National Res Centre. 44:81. https://doi. org/10.1186/s42269-020-00329-5

Lee J.S. Cha Y.J. Lee K.H. and Yim J.E. 2016. Onion peels extract reduces the percentage of body fat in overweight and obese subjects: a 12-week, randomized, double-blind, placebo-controlled study. Nutrit Res Prac. 10:175-181. https://doi.org/10.4162/ nrp.2016.10.2.175

Lee B., Fleet D. and Lee H. 2018. Compositions comprising tangeretin for preventing or treating post traumatic stress disorder. Patent No. KR102015221B1 (Korea).

Leoncini E., Edefonti V., Hashibe M., Parpinel M., Cadoni G., Ferraroni M., et al. 2016. Carotenoid intake and head and neck cancer: a pooled analysis in the international head and neck cancer epidemiology consortium. Eur J Epidemiol. 31:369-383. https://doi.org/10.1007/s10654-015-0036-3

Leporini M., Loizzo M.R., Sicari V., Pellicanò T.M., Reitano A., Dugay A., et al. 2020a. Citrus $\times$ clementina Hort. juice enriched with its by-products (peels and leaves): chemical composition, in vitro bioactivity, and impact of processing. Antioxidants. 9:298. https://doi.org/10.3390/antiox9040298

Leporini M., Tundis R., Sicari V., Pellicanò T.M., Dugay A., Deguin B., et al. 2020b. Impact of extraction processes on phytochemicals content and biological activity of Citrus $\times$ clementina Hort. Ex Tan. leaves: New opportunity for under-utilized food by-products. Food Res Int. 127:108742. https://doi.org/10.1016/j. foodres.2019.108742

Li Q. 2019. Application of the Nobiletin in preparation treatment gastric accommodation disorder remedies. Patent No. CN108619130B (China).

Li K., Cai X., Ye J. and Huang Y. 2018. Hesperetin, hesperetin and enoxolone are inhibiting the application in chloride channel. Patent No. CN108815154A (China).

Li C. and Schluesener H. 2017. Health-promoting effects of the citrus flavanone hesperidin. Crit Rev Food Sci Nutrit. 57:613-631. https://doi.org/10.1080/10408398.2014.906382

Liang W., Zhang C., Zeng W., Zhang C. and Wang L. 2015. Application of naringenin and naringin in tumor radiotherapy. Patent No. CN104940932A (China).

Liao Y. 2018. The application of naringenin and its derivative in preventing Alzheimer disease. Patent No. CN108785301A (China).

Lim Y.J., Kim J.H., Pan J.H., Kim J.K., Park T.S., Kim Y.J., et al. 2018. Naringin protects pancreatic $\beta$-Cells against oxidative stressinduced apoptosis by inhibiting both intrinsic and extrinsic pathways in insulin-deficient diabetic mice. Mol Nutrit Food Res. 62:1700810-1700820. https://doi.org/10.1002/mnfr.201700810

Lima A.C.D., Cecatti C., Fidélix M.P., Adorno M.A.T., Sakamoto I.K., Cesar T.B., et al. 2019. Effect of daily consumption of orange juice on the levels of blood glucose, lipids, and gut microbiota metabolites: controlled clinical trials. J Med Food. 22:1-9. https://doi.org/10.1089/jmf.2018.0080

Lin X., Bai F., Nie J., Lu S., Lu C., Zhu X., et al. 2016. Didymin alleviates hepatic fibrosis through inhibiting ERK and PI3K/Akt pathways via regulation of RAF kinase inhibitor protein. Cell Physiol Biochem. 40:1422-1432. https://doi.org/10.1159/000453194.

Lin L.Y., Chuang C.H., Chen H.C. and Yang K.M. 2019. Lime (Citrus aurantifolia (Christm.) Swingle) essential oils: volatile compounds, antioxidant capacity, and hypolipidemic effect. Foods. 8:398. https://doi.org/10.3390/foods8090398

Liu J., Bi R., Geng G., Cao X., He Y., Cai T., et al. 2019a. Flavonoid micromolecule compound inhibits the application in alpha-glucosidase activity drug in preparation. Patent No. CN109806272A (China).

Liu D., Cao X., Kong Y., Mu T. and Liu J. 2020. Inhibitory mechanism of sinensetin on $\alpha$-glucosidase and non-enzymatic glycation: Insights from spectroscopy and molecular docking analyses. Int J Biol Macromol. 8130:34826-34831. https://doi. org/10.1016/j.ijbiomac.2020.10.174

Liu Y., Han J., Zhou Z. and Li D. 2019b. Tangeretin inhibits streptozotocin-induced cell apoptosis via regulating NF-кB pathway in INS-1 cells. J Cell Biochem. 120:3286-3293. https://doi. org/10.1002/jcb.27596

Loizzo M.R., Leporini M., Sicari V., Falco T., Pellicanò T.M. and Tundis R. 2018. Investigating the in vitro hypoglycaemic and antioxidant properties of Citrus $\times$ clementina hort. juice. Eur Food Res Technol. 244:523-534. https://doi.org/10.1007/ s00217-017-2978-z

Loizzo M.R., Sicari V., Tundis R., Leporini M., Falco T. and Calabrò V. 2019. The influence of ultrafiltration of Citrus limon L. Burm. cv. Femminello comune juice on its chemical composition and antioxidant and hypoglycemic properties. Antioxidants. 8:23-43. https://doi.org/10.3390/antiox8010023

Lombardo G.E., Cirmi S., Musumeci L., Pergolizzi S., Maugeri A., Russo C., et al. 2020. Mechanisms underlying the anti-inflammatory activity of bergamot essential oil and its antinociceptive effects. Plants. 9:704. https://doi.org/10.3390/plants9060704.

Lone J., Parray H.A. and Yun J.W. 2018. Nobiletin induces brown adipocyte-like phenotype and ameliorates stress in 3T3-L1 adipocytes. Biochimie. 146:197-104. https://doi.org/10.1016/j. biochi.2017.11.021

Long X., Zeng X., Yan H., Xu M., Zeng Q., Xu Citrus, et al. 2021. Flavonoids composition and antioxidant potential assessment of extracts from Gannanzao Navel Orange (Citrus sinensis Osbeck cv. Gannanzao) peel. Nat Prod Res. 35:702-706. https://doi.org/ 10.1080/14786419.2019.1593162

López Muñozmaría F., González Trujano E. and Carballo Villalobos A. 2015. Pharmaceutical composition combining diosmin and hesperidin and its use in neuropathic pain. Patent No. WO2015019334A1 (Worldwide).

Lu J.F., Zhu M.Q., Zhang H., Liu H., Xia B., Wang Y.L., et al. 2020. Neohesperidin attenuates obesity by altering the composition of the gut microbiota in high-fat diet-fed mice. FASEB J. 34:1205312071. https://doi.org/10.1096/fj.201903102RR

Lv X., Zhao S., Ning Z., Zeng H., Shu Y., Tao O., et al. 2015. Citrus fruits as a treasure trove of active natural metabolites that potentially provide benefits for human health. Chem. Central J. 9:68-82. https://doi.org/10.1186/s13065-015-0145-9

Magalhães M., Ionta M., Ferreira G., Campidelli M., Nelson D., Ferreira V., et al. 2019. Biological activities of the essential oil from the Moro orange peel (Citrus sinensis (L.) Osbeck). Flavour Frag J. 35:294-301. https://doi.org/10.1002/ffj.3561

Mahato N., Sharma K., Sinha M. and Choa M.H. 2018. Citrus waste derived nutra-pharmaceuticals for health benefits: current 
trends and future perspectives. J Funct Foods. 40:307-316. https://doi.org/10.1016/j.jff.2017.11.015

Mahato N., Sinha M., Sharma K., Koteswararao R. and Cho M.H. 2019. Modern extraction and purification techniques for obtaining high purity food-grade bioactive compounds and value-added co-products from Citrus wastes. Foods. 8:523-604. https://doi.org/10.3390/foods8110523

Mahmoud A.M., Ahmed O.M., Ashour M.B. and Abdel-Moneim A. 2015. In vivo and in vitro antidiabetic effects of Citrus flavonoids; a study on the mechanism of action. Int J Diabetes Developing Countries. 35:250-263. https://doi.org/10.1007/ s13410-014-0268-x

Mandal S.M., Chakraborty D. and Dey S. 2010. Phenolic acids act as signaling molecules in plant-microbe symbioses. Plant Signal Behav. 5:359-368. https://doi.org/10.4161/psb.5.4.10871

Mathesius U. 2018. Flavonoid functions in plants and their interactions with other organisms. Plants. 7:30. https://doi.org/10.3390/ plants7020030

Matias E.E.F., Alves E.F., Silva M.K.N., Carvalho V.R.A., Figueredo F.G., Ferreira J.V.A., et al. 2016. Seasonal variation, chemical composition and biological activity of the essential oil of Cordia verbenacea DC (Boraginaceae) and the sabinene. Ind Crops Prods. 87:45-53. https://doi.org/10.1016/j.indcrop.2016.04.028

Menichini F., Tundis R., Loizzo M.R., Bonesi M., D’Angelo D., Lombardi P. et al. 2016. Citrus medica L. cv. Diamante (Rutaceae) peels extract improves glycaemic status of Zucker diabetic fatty (ZDF) rats and protects against oxidative stress. J Enzy Inhib Med Chem. 31:1270-1276. https://doi.org/10.3109/1 4756366.2015.1115400

Milanezi F.G., Meireles L.M., De Christo Scherer M.M., Oliveira J., Da Silva A.R., De Araujo M.L., et al. 2019. Antioxidant, antimicrobial and cytotoxic activities of gold nanoparticles capped with quercetin. Saudi Pharm J. 27:968-974. https://doi.org/10.1016/j. jsps.2019.07.005

Milne G.W.A. 2005. “Gardner's Commercially Important Chemicals: Synonyms, Trade Names, and Properties," 1st ed. Wiley-Interscience, New York, NY, USA.

Mitrea D.R., Malkey R., Florian T.L., Filip A., Clichici S., Bidian C., et al. 2020. Daily oral administration of chlorogenic acid prevents the experimental carrageenan-induced oxidative stress. J Physiol Pharmacol. 71:55-65. https://doi.org/10.26402/jpp.2020.1.04

Mitropoulou G., Nikolaou A., Santarmaki V., Sgouros G. and Kourkoutas Y. 2020. Citrus medica and Cinnamomum zeylanicum essential oils as potential biopreservatives against spoilage in low alcohol wine products. Foods. 9:577. https://doi.org/10.3390/ foods 9050577

Mohammadi M., Eghtesadi S., Vafa M., Heidari I., Salehi M., Shirbeigi M., et al. 2016. The effect of hesperidin supplementation on indices of glucose and lipid, insulin levels and insulin resistance in patients with type 2 diabetes: a randomized double-blind clinical trial. Razi J Med Sci. 23:71-80.

Nair S.A., Sr R.K., Nair A.S. and Baby S. 2018. Citrus peels prevent cancer. Phytomedicine. 50:231-237. https://doi.org/10.1016/j. phymed.2017.08.011

Nakajima A., Aoyama Y., Shin E.J., Nam Y., Kim H.C., Nagai T., et al. 2015. Nobiletin, a Citrus flavonoid, improves cognitive impairment and reduces soluble $\mathrm{A} \beta$ levels in a triple transgenic mouse model of Alzheimer's disease (3XTg-AD). Behav Brain Res 289:69-77. https://doi.org/10.1016/j.bbr.2015.04.028

Nakajima A. and Ohizumi Y. 2019. Potential benefits of nobiletin, a Citrus flavonoid, against Alzheimer's disease and Parkinson's disease. Int J Mol Sci. 20:3380. https://doi.org/10.3390/ ijms20143380

Nataraj J., Manivasagam T., Thenmozhi A.J. and Essa M.M. 2016. Lutein protects dopaminergic neurons against MPTP-induced apoptotic death and motor dysfunction by ameliorating mitochondrial disruption and oxidative stress. Nutr. Neurosci. 19:237-246. https://doi.org/10.1179/1476830515Y.0000000010

Nidhi P., Rolta R., Kumar V., Dev K. and Sourirajan A. 2020. Synergistic potential of Citrus aurantium L. essential oil with antibiotics against Candida albicans. J Ethnopharmacol. 262:113-135. https://doi.org/10.1016/j.jep.2020.113135

Nyane N.A., Tlaila T.B., Malefane T.G., Ndwandwe D.E. and Owira P.M.O. 2017. Metformin-like antidiabetic, cardio-protective and non-glycemic effects of naringenin: Molecular and pharmacological insights. Eur J Pharmacol. 803:103-111. https://doi. org/10.1016/j.ejphar.2017.03.042

Oboh G., Agunloye O.M., Adefegha S.A., Akinyemi A.J. and Ademiluyi A.O. 2015a. Caffeic and chlorogenic acids inhibit key enzymes linked to type 2 diabetes (in vitro): a comparative study. J Basic Clin Physiol Pharmacol. 26:165-170. https://doi. org/10.1515/jbcpp-2013-0141

Oboh G., Bello F., Ademosun A., Akinyemi A. and Adewuni T. 2015b. Antioxidant, hypolipidemic, and anti-angiotensin-1-converting enzyme properties of lemon (Citrus limon) and lime (Citrus aurantifolia) juices. Comp Clin Pathol. 24:1395-1406. https://doi.org/10.1007/s00580-015-2088-x

Oboh G., Olasehinde T.A. and Ademosun A.O. 2017. Inhibition of enzymes linked to type- 2 diabetes and hypertension by essential oils from peels of orange and lemon. Int J Food Prop. 20:586594. https://doi.org/10.1080/10942912.2017.1303709

Oikeh E., Oviasogie F. and Omoregie E. 2020. Evaluation of antimicrobial efficacy of ethanol extracts of fresh Citrus sinensis (sweet orange) seeds against selected bacterial strains. J Appl Sci Environ Manag. 24.249-252. https://doi.org/10.4314/jasem.v24i2.9

Olabanji O., Olukayode A., Ezekiel A., Olugbenga K.O. and Adefemi G. 2016. Physicochemical and in vitro antimicrobial activity of the oils and soap of the seed and peel of Citrus sinensis. African J Microbiol Res. 10:245-253. https://doi. org/10.5897/AJMR2015.7797

Ordóñez-Díaz J.L., Hervalejo A., Pereira-Caro G., MuñozRedondo J.M., Romero-Rodríguez E., Arenas-Arenas F.J., et al. 2020. Effect of rootstock and harvesting period on the bioactive compounds and antioxidant activity of two orange cultivars ("Salustiana" and "Sanguinelli") widely used in juice industry. Processes, 8:1212. https://doi.org/10.3390/pr8101212

Osarumwense O. 2017. Anti-inflammatory activity of methanoilc and ethanolic extracts of Citrus sinensis peel (L) Osbeck on carrageenan-induced paw oedema in wistar rats. J Appl Sci Environ Manag. 21:1223-1242. https://doi.org/10.4314/jasem.v21i6.37

Oyedemi S., Nwaogu G., Chukwuma C., Adeyemi O., Matsabisa M., Swain S., et al. 2019. Quercetin modulates hyperglycemia by 
improving the pancreatic antioxidant status and enzymes activities linked with glucose metabolism in type 2 diabetes model of rats: in silico studies of molecular interaction of quercetin with hexokinase and catalase. J Food Biochem. 44:e13127. https://doi. org/10.1111/jfbc.13127

Pallavi M., Ramesh C.K., Krishna V. and Sameera P. 2018. Peels of Citrus fruits: a potential source of anti-inflammatory and antinociceptive agents. Pharmacog J. 10:172-178. https://doi. org/10.5530/pj.2018.6s.30

Park J., Kim H.L., Jung Y., Ahn K.S., Kwak H.J. and Um J.Y. 2019. Bitter orange (Citrus aurantium Linné) improves obesity by regulating adipogenesis and thermogenesis through AMPK activation. Nutrients. 11:1988-2004. https://doi.org/10.3390/ nu11091988

Paul S., Das S., Tanvir E.M., Hossen M.S., Saha M., Afroz R., et al. 2017. Protective effects of ethanolic peel and pulp extracts of Citrus macroptera fruit against isoproterenol-induced myocardial infarction in rats. Biomed Pharmacother. 94:256-264. https://doi.org/10.1016/j.biopha.2017.07.080

Paul S., Hossen Md. S., Tanvir E.M., Islam A., Afroz R., Ahmmed I., et al. 2015. Antioxidant properties of Citrus macroptera fruit and tts in vivo effects on the liver, kidney and pancreas in wistar rats. Int J Pharmacol. 11:899-909. https://doi.org/10.3923/ ijp.2015.899.909

Perdones A., Escriche I., Chiralt A. and Vargas M. 2015. Effect of chitosan-lemon essential oil coatings on volatile profile of strawberries during storage. Food Chem. 197:979-986. https://doi. org/10.1016/j.foodchem.2015.11.054

Pereira I.M.C., Matos Neto J.D., Figueiredo R.W, Carvalho J.D.G., Figueiredo E.A.T., de Menezes N.V.S., et al. 2020. Physicochemical characterization, antioxidant activity, and sensory analysis of beers brewed with cashew peduncle (Anacardium occidentale) and orange peel (Citrus sinensis). Food Sci Technol. 40:749-755. https://doi.org/10.1590/fst.17319

Pisoschi A.M. and Pop A. 2015. The role of antioxidants in the chemistry of oxidative stress: A review. Eur J Med Chem. 97:5574. https://doi.org/10.1016/j.ejmech.2015.04.040

Prakash S., Nagaraj E., Subashini K., Kanaga S., Dhandapani R., Magudeeswaran S., et al. 2020. Isolation of hesperetin - a flavonoid from Cordia sebestena flower extract through antioxidant assay guided method and its antibacterial, anticancer effect on cervical cancer via in vitro and in silico molecular docking studies. J Mol Struc. 1207:127751. https://doi.org/10.1016/j. molstruc.2020.127751

Prasatthong P., Meephat S., Rattanakanokchai S., Bunbupha S., Prachaney P., Maneesai P., et al. 2021. Hesperidin ameliorates signs of the metabolic syndrome and cardiac dysfunction via IRS/Akt/GLUT4 signaling pathway in a rat model of diet-induced metabolic syndrome. Eur J Nutrit. 60: 833-848. https:// doi.org/10.1007/s00394-020-02291-4

Prudêncio E.R-, Cardoso C.M., Castro R.N. and Riger C.J. 2019. Antioxidant effect of caffeic acid derivatives on SOD and glutathione defective yeasts. Appl Biochem Microbiol. 55:264-269 https://doi.org/10.1134/S0003683819030116

Qi G., Mi Y., Fan R., Li R., Liu Z. and Liu X. 2019. Nobiletin protects against systemic inflammation-stimulated memory impairment via MAPK and NF-кB signaling pathways. J Agri Food Chem. 67:5122-5134. https://doi.org/10.1021/acs.jafc.9b00133

Qori F., Chiuman L., Ginting C.N. and Girsang E. 2020. Effectiveness test of anti-bacterial lime juice (Citrus aurantifolia) on salmonella sp bacteria in salmon fish (Oncorhynchus nerka). J Biol Lingkungan Industri Kesehatan. 7:81-89. https://doi. org/10.31289/biolink.v7i1.3322

Rafiq S., Kaul S., Sofi S.A., Bashir N., Nazir F. and NayiK G.A. 2018. Citrus peel as a source of functional ingredient: a review. Saudi J Biol Sci 17:351-358. https://doi.org/10.1016/j.jssas. 2016.07.006

Ramli R., Ahmad Zaghlul N.S. and Ahmad Nasir N.A.H. (2020) The Potential of Antioxidants and Phytochemicals Components in Fruit Waste (Peel) of Citrus hystrix and Ananas comosus. P. 123-135. In: Alias N. and Yusof R. (eds) Charting the Sustainable Future of ASEAN in Science and Technology. Springer, Singapore. https://doi. org/10.1007/978-981-15-3434-8_11

Raspo M., Vignola M., Andreatta A. and Juliani H. 2020. Antioxidant and antimicrobial activity of Citrus essential oils from Argentina and the United States. Food Biosci 36:100651. https://doi. org/10.1016/j.fbio.2020.100651

Rehab M.A.E., Areej S.B.S. and Heelah F.A. 2018. The phytochemical and antimicrobial effect of Citrus sinensis (orange) peel powder extracts on some animal pathogens as eco-friendly. EC Microbiol. 14:312-318.

Rehman S.U., Abbasi K.S., Ul Haq N., Ahmad Q., Taran N.U., Ullah S., et al. 2020a. Comparative nutraceutical properties of seeds of eight Citrus varieties grown in Rawalpindi region. Pure Appl Biol. 9:1-9. https://doi.org/10.1590/fst.07519

Rehman K., Khan I.J., Akash M.S.H., Jabeen K., Haider K. and Tariq M. 2020b. Naringenin downregulates inflammationmediated nitric oxide overproduction and potentiates endogenous antioxidant status during hyperglycemia. J Food Biochem. 44:e13422. https://doi.org/10.1111/jfbc.13422

Rehman K., Munawar S.M., Akash M.S.H., Buabeid M.A., Chohan T.A., Tariq M., et al. 2020c. Hesperidin improves insulin resistance via downregulation of inflammatory responses: biochemical analysis and in silico validation. PLoS ONE 15:e0227637. https://doi.org/10.1371/journal.pone.0229348

Roberto D., Micucci P., Sebastian T., Graciela F. and Anesini C. 2010. Antioxidant activity of limonene on normal murine lymphocytes: relation to $\mathrm{H}_{2} \mathrm{O}_{2}$ modulation and cell proliferation. Basic Clin Pharmacol Toxicol. 106:38-44. https://doi. org/10.1111/j.1742-7843.2009.00467.x

Rombaut N., Tixier S., Bily A. and Chemat F. 2014. Green extraction processes of natural products as tools for biorefinery. Biofuels Bioprod Bioref. 8:530-544. https://doi.org/10.1002/bbb.1486

Saeb S., Mansour A., Gooybari R. and Aghel N. 2016. Evaluation of antibacterial activities of Citrus limon, Citrus reticulata, and Citrus grandis against pathogenic bacteria. Int J Enteric Pathog. 4:11-15. https://doi.org/10.15171/ijep.2016.13

Sahlan M., Damayanti V., Tristantini D., Hermansyah H., Wijanarko A. and Olivia Y. 2018. Antimicrobial activities of pummelo (Citrus maxima) seed and pulp ethanolic extract. AIP Conf Proc. 1993:030002. https://doi.org/10.1063/1.5023949 
Sahnoun M., Trabelsi S. and Bejar S. 2017. Citrus flavonoids collectively dominate the $\alpha$-amylase and $\alpha$-glucosidase inhibitions. Biologia.72:764-773.https://doi.org/10.1515/biolog-20170091

Saleem M. and Saeed M.T. 2020. Potential application of waste fruit peels (orange, yellow lemon and banana) as wide range natural antimicrobial agent. J King Saud Univ Sci. 32:805-810. https:// doi.org/10.1016/j.jksus.2019.02.013

Samie A., Sedaghat R., Baluchnejadmojarad T. and Roghani M. 2018. Hesperetin, a citrus flavonoid, attenuates testicular damage in diabetic rats via inhibition of oxidative stress, inflammation, and apoptosis. Life Sci 210:132-139. https://doi. org/10.1016/j.lfs.2018.08.074

Sangeetha R. 2019. Luteolin in the management of type 2 diabetes mellitus. Curr Res Nutrit Food Sci J. 7:393-398. https://doi. org/10.12944/CRNFSJ.7.2.09

Sathiyabama R.G., Rajiv Gandhi G., Denadai M., Sridharan G., Jothi G., Sasikumar P., et al. 2018. Evidence of insulin-dependent signalling mechanisms produced by Citrus sinensis (L.) Osbeck fruit peels in an insulin resistant diabetic animal model. Food Chem Toxicol. 116:86-99. https://doi.org/10.1016/j. fct.2018.03.050

Sato M., Goto T., Inoue E., Miyaguchi Y.T. and Oyoda A. 2019. Dietary intake of immature citrus tumida Hort. ex Tanaka peels suppressed body weight gain and fat accumulation in a mouse model of acute obesity. J Nutr. Sci Vitaminol. 65:19-23. https:// doi.org/10.3177/jnsv.65.19

Selim Y.A., Mohamed H. and Hussien S.Y. 2019. Efficacious anti-cancer property of liver from peels extract of egyptian Citrus reticulata. Austin J Nutrit Food Sci. 7:1118-1124

Shagirtha K., Bashir N. and Milton Prabu S. 2017. Neuroprotective efficacy of hesperetin against cadmium induced oxidative stress in the brain of rats. Toxicol Ind Health. 33:454-468. https://doi. org/10.1177/0748233716665301

Sharma A. and Tyagi S. 2019. Antimicrobial screening and phytochemical analysis of Citrus cultivars growing in vivo \& in vitro. J Phytologic Res. 32:35-42.

Shehata, S.A., Abdeldaym E.A., Ali, M.R., Mohamed R.M., Bob R.I. and Abdelgawad K.F. 2020. Effect of some Citrus essential oils on post-harvest shelf life and physicochemical quality of strawberries during cold storage. Agronomy. 10:1466. https://doi. org/10.3390/agronomy10101466

Shi G.J., Li Y., Cao Q.H., Wu H.X., Tang X.Y., Gao X.H., et al. 2019. In vitro and in vivo evidence that quercetin protects against diabetes and its complications: a systematic review of the literature. Biomed Pharmacother. 109:1085-1099. https://doi. org/10.1016/j.biopha.2018.10.130

Shi X. and Yang Y. 2018.The pharmaceutic usage of neohesperidin. Patent No. CN108478586 (China).

Shin H.S., Kang S.I., Ko H.C., Park D.B. and Kim S.J. 2017. Tangeretin improves glucose uptake in a coculture of hypertrophic adipocytes and macrophages by attenuating inflammatory changes. Develop Reprod 21:93-100. https://doi.org/10.12717/ DR.2017.21.1.093

Shojaemehr M., Alamholo M. and Soltani J. 2020. Investigation of antibacterial and antioxidant activity of Citrus medica extract on human pathogenic bacteria. Avicenna J Clin Microbiol Infect. 8:14. https://doi.org/10.34172/ajcmi.2020.02

Sicari V., Pellicanò T., Giuffrè A., Zappia C., Capocasale M. and Poiana M. 2018. Physical chemical properties and antioxidant capacities of grapefruit juice (Citrus paradisi) extracted from two different varieties. Int Food Res J. 25:1978-1984.

Singh B. and Sharma R.A. 2015. Plant terpenes: defense responses, phylogenetic analysis, regulation and clinical applications. Biotechnol Acad Sci. 5:129-151. https://doi.org/10.1007/s13205-014-0220-2

Singh B., Singh J.P., Kaur A. and Singh N. 2020. Phenolic composition, antioxidant potential and health benefits of Citrus peel. Food Res Int. 132:109114. https://doi.org/10.1016/j. foodres.2020.109114

Smeriglio A., Alloisio S., Raimondo F.M., Denaro M., Xiao J., Cornara L., et al. 2018. Essential oil of Citrus lumia Risso: Phytochemical profile, antioxidant properties and activity on the central nervous system. Food Chem Toxicol. 119:407-416. https://doi.org/10.1016/j.fct.2017.12.053

Smeriglio A., Cornara L., Denaro M., Barreca D., Burlando B., Xiao J., et al. 2019. Antioxidant and cytoprotective activities of an ancient Mediterranean Citrus (Citrus lumia Risso) albedo extract: microscopic observations and polyphenol characterization. Food Chem. 279:347-355. https://doi.org/10.1016/j. foodchem.2018.11.138

Su S., Li X., Li S., Ming P., Huang Y., Dong Y., et al. 2019. Rutin protects against lipopolysaccharide-induced mastitis by inhibiting the activation of the NF- $\mathrm{kB}$ signaling pathway and attenuating endoplasmic reticulum stress. Inflammopharmacology. 27:7788. https://doi.org/10.1007/s10787-018-0521-x

Sun T., Yuan H., Cao H., Yazdani M., Tadmor Y. and Li L. 2018. Carotenoid metabolism in plants: the role of plastids. Mol Plant. 11:58-74. https://doi.org/10.1016/j.molp.2017.09.010

Supatra S. 2019. The chemistry and biology of lycopene: antioxidant for human health. Int J Adv Life Sci Res. 2:8-14. https://doi. org/10.31632/ijalsr.2019v02i04.002

Tang X.P., Guo X.H., Geng D. and Weng L.J. 2019. D-Limonene protects PC12 cells against corticosterone-induced neurotoxicity by activating the AMPK pathway. Environ Toxicol Pharmacol. 70:1-6. https://doi.org/10.1016/j.etap.2019.05.001

Teneva D., Denkova-Kostova R., Goranov B., Hristova-Ivanova Y., Slavchev A., Denkova Z., et al. 2019. Chemical composition, antioxidant activity and antimicrobial activity of essential oil from Citrus aurantium $\mathrm{L}$ zest against some pathogenic microorganisms. Zeitschrift für Naturforschung C. 74:105-111. https:// doi.org/10.1515/znc-2018-0062

Terao J. 2009. Dietary flavonoids as antioxidants. Forum Nutr Home. 61:87-94. https://doi.org/10.1159/000212741

Thandiswa M., Opeoluwa O., Mavuto G. and Adebola O. 2020. Chemical composition and in vivo anti-inflammatory activity of essential oils from Citrus sinensis (1.) osbeck growing in South Africa. J Essential Oil Bear Plants. 23:638-647. https:// doi.org/10.1080/0972060X.2020.1819885

Thenmozhi J.A., Raja T.R., Janakiraman U. and Manivasagam T. 2015. Neuroprotective effect of hesperidin on aluminium chloride induced Alzheimer's disease in Wistar rats. Neurochemi Res. 40:767-776. https://doi.org/10.1007/s11064-015-1525-1 
Thomas L. and Kamath J.V. 2017. Anti-hyperglycemic activity of Citrus limon leaves in streptozotocin induced diabetic rats. Indian Drugs. 54:74-80.

Torregrosa-Crespo J., Montero Z., Fuentes J.L., García-Galbis M.R., Garbayo I., Vílchez C., et al. 2018. Exploring the valuable carotenoids for the large-scale production by marine microorganisms. Marine Drugs.16:203-228. https://doi.org/10.3390/ md16060203

Torres-Villarreal D., Camacho A., Castro H., Ortiz-Lopez R. and De la Garza A.L. 2019. Anti-obesity effects of kaempferol by inhibiting adipogenesis and increasing lipolysis in 3T3-L1 cells. J Physiol Biochem. 75:83-88. https://doi.org/10.1007/ s13105-018-0659-4

Toth P.P., Patti A.M., Nikolic D., Giglio R.V., Castellino G., Biancucci T., et al. 2016. Bergamot reduces plasma lipids, atherogenic small dense LDL, and subclinical atherosclerosis in subjects with moderate hypercholesterolemia: a 6 months prospective study. Front Pharmacol. 6:299-308. https://doi. org/10.3389/fphar.2015.00299

Tundis R., Bonesi M., Sicari V., Pellicanò T.M., Tenuta M.C., Leporini M., et al. 2016. Poncirus trifoliata (L.) Raf.: chemical composition, antioxidant properties and hypoglycaemic activity via the inhibition of $\alpha$-amylase and $\alpha$-glucosidase enzymes. J Funct Foods. 25:477-485. https://doi.org/10.1016/j. jff.2016.06.034.

Tundis R., Loizzo M.R. and Menichini F. 2010. Natural products as alpha-amylase and alpha-glucosidase inhibitors and their hypoglycaemic potential in the treatment of diabetes: an update. Mini Rev Med Chem. 10:315-331. https://doi. org/10.2174/138955710791331007

Valls R., Pedret A., Calderón-Pérez L., Llauradó E., Pla Pagà L., Companys J., et al. 2021. Effects of hesperidin in orange juice on blood and pulse pressures in mildly hypertensive individuals: a randomized controlled trial (Citrus study). Eur J Nutr. 60:12771288. https://doi.org/10.1007/s00394-020-02279-0

Varga Z.V., Matyas C. Erdelyi K., Cinar R., Nieri D., Chicca A., et al. 2018. $\beta$-Caryophyllene protects against alcoholic steatohepatitis by attenuating inflammation and metabolic dysregulation in mice. Br J Pharmacol. 175:320-334. https://doi.org/10.1111/ bph. 13722

Verma N., Yadav A., Bal S., Gupta R. and Aggarwal N. 2019. In vitro studies on ameliorative effects of limonene on cadmium-induced genotoxicity in cultured human peripheral blood lymphocytes. Biotechnol Appl Biochem. 187:1384-1397. https://doi. org/10.1007/s12010-018-2881-5

Wang Y.B., Ge Z.M., Kang W.Q., Lian Z.X., Yao J. and Zhou C.Y. 2015. Rutin alleviates diabetic cardiomyopathy in a rat model of type 2 diabetes. Exp Therap Med. 9:451-455. https://doi. org/10.3892/etm.2014.2090

Wang M., Meng D., Zhang P., Wang X., Du G., Brennan C., et al. 2018. Antioxidant protection of nobiletin, 5-demethylnobiletin, tangeretin, and 5-demethyltangeretin from Citrus peels in Saccharomyces cerevisiae. J Agri Food Chem. 66:3155-3160. https://doi.org/10.1021/acs.jafc.8b00509

Wang D., Tian L., Lv H., Pang Z., Li D., Yao Z., Wang S. 2020. Chlorogenic acid prevents acute myocardial infarction in rats by reducing inflammatory damage and oxidative stress. Biomed Pharmacother. 132:110773. https://doi.org/10.1016/j. biopha.2020.110773

Wen-Zhe M., Sen-ling F., Xiao-Jun Y., Zhong-wen Y., Liang L. and Ying X. 2015. Use of nobiletin in cancer treatment. US Patent No. US9808477B2.

Wu L.H., Lin C., Lin H.Y., Liu Y.S., Wu C.Y., Tsai C.F., et al. (2016). Naringenin Suppresses Neuroinflammatory Responses Through Inducing Suppressor of Cytokine Signaling 3 Expression. Mol Neurobiol. 53:1080-1091. https://doi.org/10.1007/ s12035-014-9042-9

Xu H., Linn B.S., Zhang Y. and Ren J. 2019. A review on the antioxidative and prooxidative properties of luteolin. React Oxygen Species. 7:136-147. https://doi.org/10.20455/ros.2019.833

Yang H. 2018. A kind of anti-oxidant lightening compositions and its application. Patent No. CN108464949A (China).

Yang T., Feng C., Wang D., Qu Y., Yang Y., Wang Y. and Sun Z. 2020. Neuroprotective and anti-inflammatory effect of tangeretin against cerebral ischemia-reperfusion injury in rats. Inflammation. 43:2332-2343. https://doi.org/10.1007/ s10753-020-01303-Z

Yang D.K. and Kang H.S. 2018. Anti-diabetic effect of cotreatment with quercetin and resveratrol in streptozotocin-induced diabetic rats. Biomol Therap. 26:130-138. https://doi.org/10.4062/ biomolther.2017.254

Young-hee K. and Min-kyung KD. 2018. Composition of improvement, prevention and treatment in renal fibrosis or cirrhosis of the kidney glomerulus or albuminuria. Patent No. KR101949471B1 (Korea).

Yu L., Yan J. and Sun Z. 2017. D-limonene exhibits antiinflammatory and antioxidant properties in an ulcerative colitis rat model via regulation of iNOS, COX-2, PGE2 and ERK signaling pathways. Mol Medicine Rep. 15:2339-2346. https://doi. org/10.3892/mmr.2017.6241

Yuan X., Wei G., You Y., Huang Y., Lee H.J., Dong M., et al. 2017. Rutin ameliorates obesity through brown fat activation. FASEB J. 31:333-345. https://doi.org/10.1096/fj.201600459RR

Zareei S., Boojar M.M.A. and Amanlou M. 2017. Inhibition of liver alanine aminotransferase and aspartate aminotransferase by hesperidin and its aglycone hesperetin: An in vitro and in silico study. Life Sci. 178:49-55. https://doi.org/10.1016/j. lfs.2017.04.001

Zeng, Z., He, W., Jia, Z. and Hao, S. 2017. Lycopene improves insulin sensitivity through inhibition of STAT3/Srebp-1c-mediated lipid accumulation and inflammation in mice fed a high-fat diet. Exp Clin Endocrinol Diabetes. 125:610-617. https://doi. org/10.1055/s-0043-101919

Zeng S.L., Li S.Z., Lai C., Wei M.Y., Chen B.Z., Li P., et al. 2018. Evaluation of anti-lipase activity and bioactive flavonoids in the Citri Reticulatae pericarpium from different harvest time. Phytomedicine. 43:103-109. https://doi.org/10.1016/j. phymed.2018.04.008

Zhang J., Fu X., Yang L., Wen H., Zhang L., Liu F., et al. 2020. Neohesperidin inhibits cardiac remodeling induced by Ang II in vivo and in vitro. Biomed Pharmacother. 129:110364. https://doi. org/10.1016/j.biopha.2020.110364 
Zhang L., Zhang X., Zhang C., Bai X., Zhang J., Zhao X., et al. 2016. Nobiletin promotes antioxidant and anti-inflammatory responses and elicits protection against ischemic stroke in vivo. Brain Res. 1636:130-141. https://doi.org/10.1016/j. brainres.2016.02.013

Zhang Z., Yang Citrus, Dai X., Ao Y. and Li Y. 2017. Inhibitory effect of trans-caryophyllene (TC) on leukocyte-endothelial attachment. Toxicol Appl Pharmacol. 329:326-333. https://doi. org/10.1016/j.taap.2017.06.016

Zulvikar S.U., Tenta H.H., Faizanah H. and Dewi S. 2020. Antibacterial activity of Citrus hystrix toward Salmonella spp. infection. Enfermedades Infecciosas y Microbiología Clínica. In Press. https://doi.org/10.1016/j.eimc.2020.05.016 